\title{
VIABILIDADE ECONÔMICA DA IRRIGAÇÃO DE PASTAGEM DE CAPIM TANZÂNIA EM DIFERENTES REGIÕES DO BRASIL
}

\author{
VAlter Dantas Pinheiro
}

Dissertação apresentada à Escola Superior de Agricultura "Luiz de Queiroz", Universidade de São Paulo, para obtenção do título de Mestre em Agronomia, Área de concentração: Irrigação e Drenagem.

\section{PIRACICABA}

Estado de São Paulo - Brasil

Janeiro - 2002 


\title{
VIABILIDADE ECONÔMICA DA IRRIGAÇÃO DE PASTAGEM DE CAPIM TANZÂNIA EM DIFERENTES REGIÕES DO BRASIL
}

\author{
VAlter Dantas Pinheiro \\ Engenheiro Agrícola \\ Orientador: Prof. Dr. RUBENS DUARTE COELHO
}

Dissertação apresentada à Escola Superior de Agricultura "Luiz de Queiroz", Universidade de São Paulo, para obtenção do título de Mestre em Agronomia, Área de concentração: Irrigação e Drenagem.

\section{PIRACICABA}

Estado de São Paulo - Brasil

Janeiro -2002 
Dados Internacionais de Catalogação na Publicação (CIP)
DIVISÃO DE BIBLIOTECA E DOCUMENTAÇÃO - ESALQ/USP

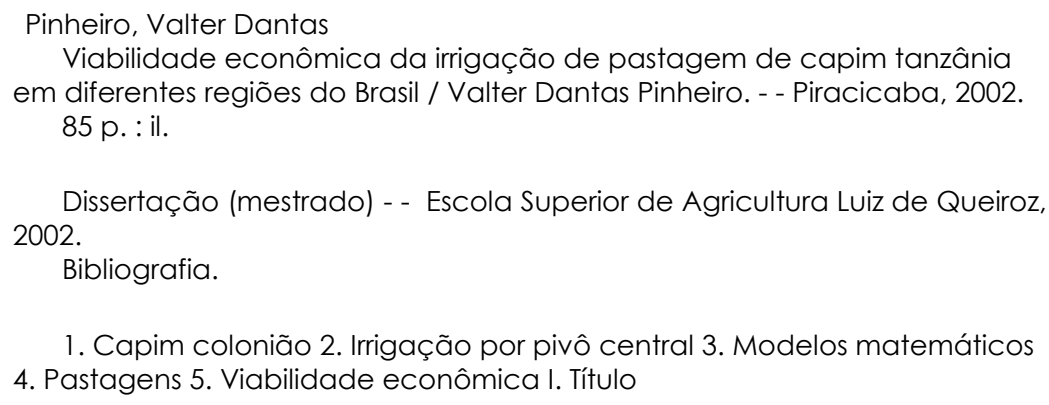

CDD 631.7

\section{"Permitida a cópia total ou parcial deste documento, desde que citada a fonte - $\mathrm{O}$ autor"}




\section{DEDICO}

A meus queridos pais, Osvaldo e Francisca

A minha irmã Vanusa

A meus sobrinhos, Delmiro e Izza

A minha namorada Amanda

"Jamais considere seus estudos como uma obrigação, mas como uma oportunidade invejável (...) para aprender a conhecer a influência libertadora da beleza do reino do Espírito, para seu próprio prazer pessoal e para proveito da comunidade à qual seu futuro trabalho pertencer"

(Mensagem de Einstein a estudantes de Princenton, EUA) 


\section{AGRADECIMENTOS}

A Deus pela fé e esperança;

A meus pais pelos esforços, pela compreensão e pelo apoio na formação moral e intelectual dos seus filhos;

À Escola Superior de Agricultura "Luiz de Queiroz" (ESALQ/USP), através do Departamento de Engenharia Rural, pelo apoio dispensado e pelo acolhimento;

Ao Conselho Nacional de Desenvolvimento Científico e Tecnológico (CNPq), pela concessão de bolsa de estudos;

À Fundação de Auxílio à Pesquisa do Estado de São Paulo (FAPESP), pelo suporte financeiro dessa pesquisa, de acordo com o projeto $n^{0}$ 99/12582-5: Funções de resposta "Produtividade do capim tanzânia (Panicum maximum Jacq cv. tanzânia) em função da lâmina de irrigação e doses de nitrogênio";

Ao Prof. Dr. Rubens Duarte Coelho, pelos ensinamentos oferecidos, pela orientação, pela amizade e pelo incentivo;

Aos Prof. Dr. André Luiz Teixeira Fernandes, Dr. Dante Pazzanese Duarte Lanna e Dr. Nilson Augusto Villa Nova, pelas valiosas sugestões e pelas colaborações;

Ao colega Leandro Fellet Lourenço (UFA), pela grande colaboração, pelos ensinamentos, pelas sugestões e pelo companheirismo;

Ao colega Luís Geraldo, pelos ensinamentos, pelas sugestões e pelo companheirismo;

Ao Grupo de Práticas em Irrigação e Drenagem (GPID), Ithamar, Adriano, Rafael, Alex, Camila, Vivian, Marcos, pela ajuda na coleta de dados de campo, pelo companheirismo e pela amizade; 
Aos professores e colegas do Curso de Pós-Graduação em Irrigação e Drenagem, que, formal ou informalmente, contribuíram em minha formação científica e moral;

A Amanda Barros e a família, pelo carinho, pelo incentivo e pelo apoio em todos os momentos;

Aos colegas Luis Fernando, Rafael, Rodrigo e Chryz pelo companheirismo e pela amizade;

Aos amigos Luciano, Marcelo, Delmiro, Thiago, Taciano, Juliano, Alessandro, Anderson, Sávio e Darci pelo incentivo e pela amizade;

Aos funcionários do DER-ESALQ/USP, Davilmar, Sandra, César, Hélio, Antônio, Gilmar e Osvaldo, pelo apoio e pela atenção. 


\section{SUMÁRIO}

\begin{tabular}{|c|c|}
\hline & Página \\
\hline $\begin{array}{l}\text { LISTA DE FIGURAS. } \\
\text { LISTA DE TABELAS. }\end{array}$ & viii \\
\hline RESUMO.......................... & xiv \\
\hline SUMMARY.... & $\mathrm{xvi}$ \\
\hline 1 INTRODUÇÃO & 1 \\
\hline 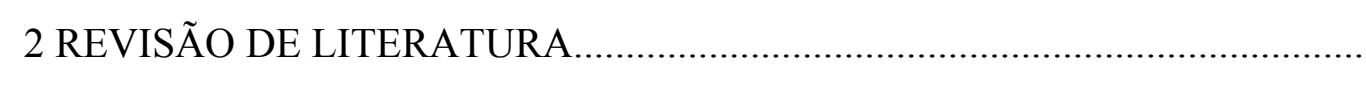 & 3 \\
\hline 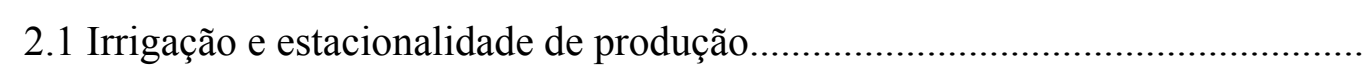 & 3 \\
\hline 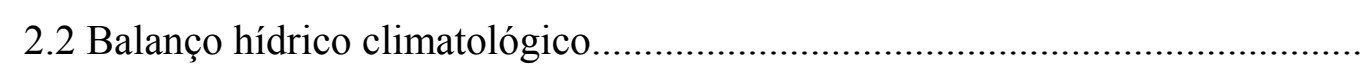 & 4 \\
\hline 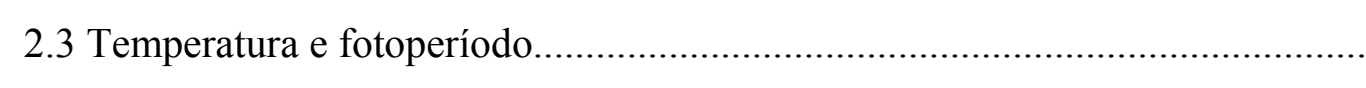 & 6 \\
\hline 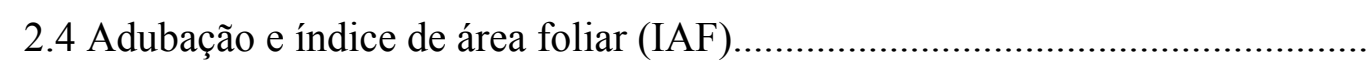 & 7 \\
\hline 2.5 Modelos matemáticos & 9 \\
\hline 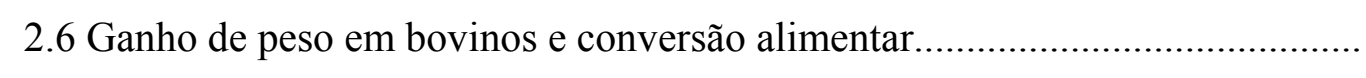 & 11 \\
\hline 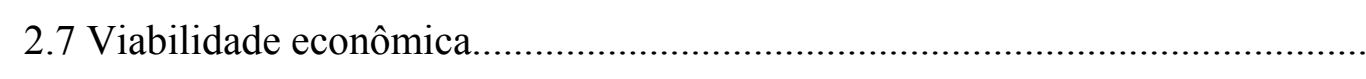 & 14 \\
\hline 3 MATERIAL E MÉTODOS................................................. & 19 \\
\hline 3.1 Condução da irrigação............. & 21 \\
\hline 3.2 Produção de forragem............ & 21 \\
\hline 3.3 A unidade fototérmica............................ & 22 \\
\hline 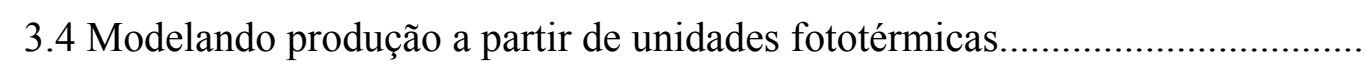 & 24 \\
\hline 3.5 Índice de área foliar. & 25 \\
\hline 3.6 Avaliação econômica. & 26 \\
\hline 4 RESULTADOS E DISCUSSÃO & 31 \\
\hline 4.1 Condução da irrigação.............................. & 31 \\
\hline
\end{tabular}


4.2 Produção de matéria seca (MS).................................................................. 32

4.3 Cálculo da unidade fototérmica..................................................................... 34

4.4 Ajuste dos modelos de estimativa de produção de matéria seca........................ 35

4.5 Índice de área foliar................................................................................... 40

4.6 Avaliação econômica...................................................................................... 41

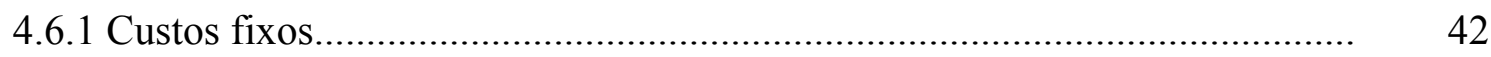

4.6.1.1 Custos do sistema de irrigação................................................................

4.6.1.2 Custo de formação da pastagem e cerca elétrica........................................ 43

4.6.1.3 Custo da Mão-de-obra............................................................................ 45

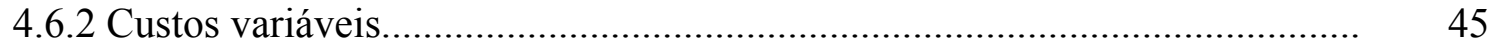

4.6.3 Simulação de viabilidade econômica da irrigação em pastagem..................... 46

4.6.4 Simulação de viabilidade econômica da irrigação em pastagem para várias

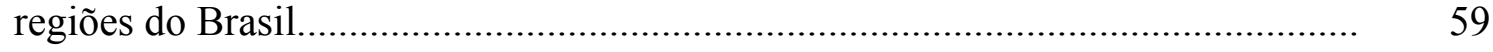

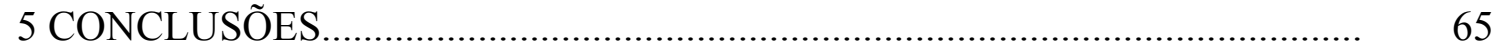

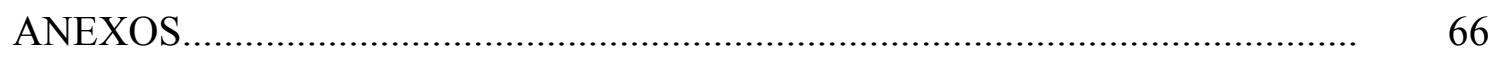

REFERÊNCIAS BIBLIOGRÁFICAS............................................................... 77 


\section{LISTA DE FIGURAS}

Página

1 Lay out da área do experimento na Fazenda Areão.......................................... 19

2 Foto aérea do experimento na Fazenda Areão.................................................. 20

3 Variações das leituras tensiométricas no experimento na Fazenda Areão, nos

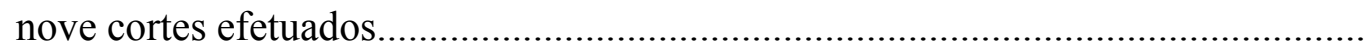

4 Produção de matéria seca por coleta $\left(\mathrm{kg} \mathrm{MS} \mathrm{ha}^{-1}\right)$ do capim tanzânia, durante o período experimental de 02/01/01 à 21/12/01

5 Ajuste entre os dados observados de produção de matéria seca e as unidade fototérmicas para o capim tanzânia, dose $0 \mathrm{~kg} \mathrm{~N} \mathrm{ha}^{-1} \mathrm{ano}^{-1}$ (período de crescimento de 36 dias)

6 Ajuste entre os dados observados de produção de matéria seca e as unidade fototérmicas para o capim tanzânia, dose $100 \mathrm{~kg} \mathrm{~N} \mathrm{ha}^{-1} \mathrm{ano}^{-1}$ (período de crescimento de 36 dias).

7 Ajuste entre os dados observados de produção de matéria seca e as unidade fototérmicas para o capim tanzânia, dose $275 \mathrm{~kg} \mathrm{~N} \mathrm{ha}^{-1} \mathrm{ano}^{-1}$ (período de crescimento de 36 dias).

8 Ajuste entre os dados observados de produção de matéria seca e as unidade fototérmicas para o capim tanzânia, dose $756 \mathrm{~kg} \mathrm{~N} \mathrm{ha}^{-1} \mathrm{ano}^{-1}$ (período de crescimento de 36 dias).

9 Ajuste entre os dados observados de produção de matéria seca e as unidade fototérmicas para o capim tanzânia, dose $2079 \mathrm{~kg} \mathrm{~N} \mathrm{ha}^{-1} \mathrm{ano}^{-1}$ (período de crescimento de 36 dias). 
10 Valores observados e ajustados de produção de matéria seca em função das unidades fototérmica disponíveis e doses de $0,100,275,756$ e $2079 \mathrm{~kg} \mathrm{~N}^{-1}$

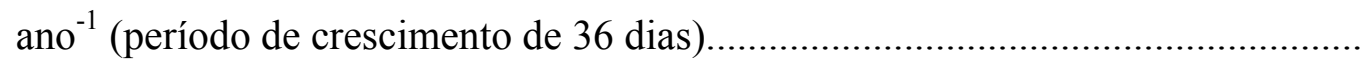

11 Características climáticas da região de Piracicaba - SP (Latitude $22^{\circ} 33$ 'S, Longitude $47^{\circ} 43^{\prime} \mathrm{W}$ ) e $490 \mathrm{~m}$ de altitude

12 Características climáticas da região de Aragarças - GO (Latitude 1554'S, Longitude $\left.52^{\circ} 13^{\prime} \mathrm{W}\right)$ e $345 \mathrm{~m}$ de altitude.....

13 Produção de MS do capim tanzânia, ao longo do ano, para região de Piracicaba - SP com adubação de $600 \mathrm{~kg} \mathrm{~N} \mathrm{ha}^{-1} \mathrm{ano}^{-1}$....

14 Produção de MS do capim tanzânia, ao longo do ano, para região de Aragarças - GO com adubação de $600 \mathrm{~kg} \mathrm{~N} \mathrm{ha}^{-1} \mathrm{ano}^{-1}$.

15 Estudo da viabilidade de pastagem irrigada para Piracicaba-SP, simulando os seguintes fatores: ganho de peso diário dos animais $(0,50,0,75$ e 1,00 $\mathrm{kg}$ de PV $\left.\operatorname{dia}^{-1}\right)$, níveis de adubação $\left(300,600\right.$ e $900 \mathrm{~kg} \mathrm{~N} \mathrm{ha}^{-1}$ ano $\left.^{-1}\right)$, preço de venda da arroba (35, 40 e 45 R\$/@).....

16 Estudo da viabilidade de pastagem irrigada para Aragarças - GO, simulando os seguintes fatores: ganho de peso diário dos animais $(0,50,0,75$ e 1,00 kg de PV dia $\left.^{-1}\right)$, níveis de adubação $\left(300,600\right.$ e $900 \mathrm{~kg} \mathrm{~N} \mathrm{ha}^{-1}$ ano $\left.^{-1}\right)$, preço de venda da arroba (35,40 e 45 R\$/@)

17 Estudo da viabilidade de pastagem de sequeiro para Piracicaba - SP, simulando os seguintes fatores: ganho de peso diário dos animais $(0,50,0,75 \mathrm{e}$ $1,00 \mathrm{~kg}$ de PV dia $\left.{ }^{-1}\right)$, níveis de adubação $\left(300,600\right.$ e $\left.900 \mathrm{~kg} \mathrm{~N} \mathrm{ha}^{-1} \mathrm{ano}^{-1}\right)$, preço de venda da arroba (35, 40 e 45 R\$/@)....

18 Estudo da viabilidade de pastagem de sequeiro para Aragarças - GO, simulando os seguintes fatores: ganho de peso diário dos animais $(0,50,0,75 \mathrm{e}$ $1,00 \mathrm{~kg}$ de PV dia $\left.{ }^{-1}\right)$, níveis de adubação $\left(300,600\right.$ e $\left.900 \mathrm{~kg} \mathrm{~N} \mathrm{ha}^{-1} \mathrm{ano}^{-1}\right)$, preço de venda da arroba (35, 40 e 45R\$/@).....

19 Rentabilidade da pastagem irrigada para Piracicaba - SP, simulando-se os seguintes fatores: ganho de peso diário dos animais, nível de adubação, preço de venda da arroba e tipo de manejo dos animais 
20 Rentabilidade da pastagem irrigada para Aragarças - GO, simulando-se os seguintes fatores: ganho de peso diário dos animais, nível de adubação, preço de venda da arroba e tipo de manejo dos animais.

21 Rentabilidade da pastagem de sequeiro para Piracicaba - SP, simulando-se os seguintes fatores: ganho de peso diário dos animais, nível de adubação, preço de venda da arroba e tipo de manejo dos animais.

22 Rentabilidade da pastagem de sequeiro para Aragarças - GO, simulando-se os seguintes fatores: ganho de peso diário dos animais, nível de adubação, preço de venda da arroba e tipo de manejo dos animais

23 Estudo da rentabilidade de pastagem irrigada para 25 municípios brasileiros, avaliando os seguintes fatores: receita liquida, lotação média anual e taxa interna de retorno.

24 Estudo da rentabilidade de pastagem sequeiro para 25 municípios brasileiros, avaliando os seguintes fatores: receita liquida, lotação média anual e taxa interna de retorno. 


\section{LISTA DE TABELAS}

Página

1 Médias de produção de matéria seca por pastejo ( $\mathrm{kg} \mathrm{MS} \mathrm{ha}^{-1}$ ) no capim tanzânia, em função dos níveis de adubação nitrogenada, em diferentes períodos de corte

2 Dados meteorológicos, fotoperíodo (N), unidades fototérmica (UF), nas épocas correspondentes a cada corte, ano agrícola de 2001, em Piracicaba-SP, $\left(\right.$ Lat $\left.=22,71^{\circ} \mathrm{S}\right)$

3 Médias do índice de área foliar no capim tanzânia, em função dos níveis de adubação nitrogenada, nos diferentes períodos de corte.

4 Características hipotéticas para projeto do sistema de irrigação tipo pivô central.

5 Levantamento dos custos de aquisição de um sistema de irrigação, tipo pivô central.

6 Custo da formação de pastagem, considerando-se uma área hipotética de implantação do sistema de pastagem irrigado e sequeiro.

7 Custo da cerca elétrica, com uma vida útil de 10 anos, para uma área de 102,95 ha, divididos em 36 piquetes.

8 Custos variáveis do manejo de pastagem irrigada e adubada e pastagem de sequeiro adubada, levando-se em consideração as despesas com, adubação e custeio anual dos animais.

9 Lâmina de irrigação e custo elétrico $\left(\mathrm{R} \$\right.$ mês $\left.^{-1}\right)$ na área irrigada na região de Piracicaba - SP. 
10 Lâmina de irrigação e custo elétrico $\left(\mathrm{R} \$\right.$ mês $\left.^{-1}\right)$ da área irrigada na região de Aragarças - GO

11 Produção total do capim tanzânia kg MS ha ${ }^{-1}$ ano $^{-1}$ com adubação de 300, 600 e $900 \mathrm{~kg} \mathrm{~N} \mathrm{ha}^{-1} \mathrm{ano}^{-1}$......

12 Simulação da viabilidade econômica da pastagem irrigada e de sequeiro, para 25 municípios brasileiros

13 Temperatura máxima $\left(\mathrm{Tx},{ }^{\circ} \mathrm{C}\right)$, temperatura mínima $\left(\mathrm{Tm},{ }^{\circ} \mathrm{C}\right)$, temperatura média $\left(\mathrm{T},{ }^{\circ} \mathrm{C}\right)$ e chuva $(\mathrm{P}, \mathrm{mm})$ referentes ao $1^{\mathrm{o}}$ corte, ano agrícola de 2001. Fazenda Areão - ESALQ/USP, Piracicaba - SP.

14 Temperatura máxima $\left(\mathrm{Tx},{ }^{\circ} \mathrm{C}\right)$, temperatura mínima $\left(\mathrm{Tm},{ }^{\circ} \mathrm{C}\right)$, temperatura média $\left(\mathrm{T},{ }^{\circ} \mathrm{C}\right)$ e chuva $(\mathrm{P}, \mathrm{mm})$ referentes ao $2^{\circ}$ corte, ano agrícola de 2001. Fazenda Areão - ESALQ/USP, Piracicaba - SP.

15 Temperatura máxima $\left(\mathrm{Tx},{ }^{\circ} \mathrm{C}\right)$, temperatura mínima $\left(\mathrm{Tm},{ }^{\circ} \mathrm{C}\right)$, temperatura média $\left(\mathrm{T},{ }^{\circ} \mathrm{C}\right)$ e chuva $(\mathrm{P}, \mathrm{mm})$ referentes ao $3^{\circ}$ corte, ano agrícola de 2001. Fazenda Areão - ESALQ/USP, Piracicaba - SP.

16 Temperatura máxima $\left(\mathrm{Tx},{ }^{\circ} \mathrm{C}\right)$, temperatura mínima $\left(\mathrm{Tm},{ }^{\circ} \mathrm{C}\right)$, temperatura média $\left(\mathrm{T},{ }^{\circ} \mathrm{C}\right)$ e chuva $(\mathrm{P}, \mathrm{mm})$ referentes ao $4^{\mathrm{o}}$ corte, ano agrícola de 2001. Fazenda Areão - ESALQ/USP, Piracicaba - SP.

17 Temperatura máxima $\left(\mathrm{Tx},{ }^{\circ} \mathrm{C}\right)$, temperatura mínima $\left(\mathrm{Tm},{ }^{\circ} \mathrm{C}\right)$, temperatura média $\left(\mathrm{T},{ }^{\circ} \mathrm{C}\right)$ e chuva $(\mathrm{P}, \mathrm{mm})$ referentes ao $5^{\circ}$ corte, ano agrícola de 2001. Fazenda Areão - ESALQ/USP, Piracicaba - SP.

18 Temperatura máxima $\left(\mathrm{Tx},{ }^{\circ} \mathrm{C}\right)$, temperatura mínima $\left(\mathrm{Tm},{ }^{\circ} \mathrm{C}\right)$, temperatura média $\left(\mathrm{T},{ }^{\circ} \mathrm{C}\right)$ e chuva $(\mathrm{P}, \mathrm{mm})$ referentes ao $6^{\circ}$ corte, ano agrícola de 2001. Fazenda Areão - ESALQ/USP, Piracicaba - SP.

19 Temperatura máxima $\left(\mathrm{Tx},{ }^{\circ} \mathrm{C}\right)$, temperatura mínima $\left(\mathrm{Tm},{ }^{\circ} \mathrm{C}\right)$, temperatura média $\left(\mathrm{T},{ }^{\circ} \mathrm{C}\right)$ e chuva $(\mathrm{P}, \mathrm{mm})$ referentes ao $7^{\circ}$ corte, ano agrícola de 2001. Fazenda Areão - ESALQ/USP, Piracicaba - SP.

20 Temperatura máxima $\left(\mathrm{Tx},{ }^{\circ} \mathrm{C}\right)$, temperatura mínima $\left(\mathrm{Tm},{ }^{\circ} \mathrm{C}\right)$, temperatura média $\left(\mathrm{T},{ }^{\circ} \mathrm{C}\right)$ e chuva $(\mathrm{P}, \mathrm{mm})$ referentes ao $8^{\circ}$ corte, ano agrícola de 2001. Fazenda Areão - ESALQ/USP, Piracicaba - SP. 
21 Temperatura máxima $\left(\mathrm{Tx},{ }^{\circ} \mathrm{C}\right)$, temperatura mínima $\left(\mathrm{Tm},{ }^{\circ} \mathrm{C}\right)$, temperatura média $\left(\mathrm{T},{ }^{\circ} \mathrm{C}\right)$ e chuva $(\mathrm{P}, \mathrm{mm})$ referentes ao $9^{\circ}$ corte, ano agrícola de 2001. Fazenda Areão - ESALQ/USP, Piracicaba - SP.

22 Preço das Tarifas Horo-sazonais Verde de Consumo e Demanda para três regiões brasileiras: Sudeste - Companhia Paulista de Força e Luz, 19/10/2001 (CPFL); Nordeste - Companhia Energética de Pernambuco, 19/10/2001 (CELPE) e Centro Oeste - Companhia Energética de Goiás S/A, 30/10/2001 (CELG) 


\title{
VIABILIDADE ECONÔMICA DA IRRIGAÇÃO DE PASTAGEM DE CAPIM TANZÂNIA EM DIFERENTES REGIÕES DO BRASIL
}

\author{
Autor: Valter Dantas Pinheiro \\ Orientador: Prof. Dr. Rubens Duarte Coelho
}

\section{RESUMO}

A estacionalidade da produção de forragens é um fator de grande importância, porque se relaciona com os baixos índices de lucratividade na pecuária de corte nacional. Nos últimos 5 anos, alguns pecuaristas capitalizados dos Estados de Goiás e Mato Grosso do Sul, implantaram aproximadamente, 120 equipamentos de irrigação (pivô central), totalizando cerca de 10.000 ha de pastagens irrigadas com gado de corte no Brasil Central. Os resultados econômicos obtidos até o presente momento, apresentam-se variáveis e imprevisíveis, sendo que alguns pecuaristas já apresentaram insucessos na condução desses projetos, enquanto outros, demonstram lucros surpreendentes para esse setor agropecuário. O objetivo dessa pesquisa é apresentar uma metodologia de análise econômica da viabilidade de irrigação de pastagens em diferentes regiões do Brasil, estimando-se a produtividade do capim tanzânia irrigado, através de um modelo matemático, calibrado em um experimento de campo, conduzido no município de Piracicaba - SP, com base na disponibilidade mensal local de unidades fototérmicas (temperatura e fotoperíodo) para diferentes níveis de adubações nitrogenadas. No estudo realizado, foram ajustados os parâmetros da função de Gompertz para as diferentes doses de adubação nitrogenada analisadas, sendo os melhores ajustes observados para as maiores dosagens de nitrogênio: 275, 756 e $2079 \mathrm{~kg}$ 
$\mathrm{N} \mathrm{ha}^{-1}$ ano $^{-1}$ com $\mathrm{r}^{2}=0,9650 ; 0,8938$ e 0,9784 respectivamente; já as menores dosagens estudadas, 0 e $100 \mathrm{~kg} \mathrm{~N}^{-1} \mathrm{ano}^{-1}$, a equação ajustada apresentou precisão moderada para estimativa da produção, $\mathrm{r}^{2}=0,7047$ e 0,7112 respectivamente. As simulações efetuadas da viabilidade econômica da irrigação (pivô central elétrico) em pastagens de capim tanzânia em território nacional apresentaram retornos econômicos interessantes (R\$ 400,00 a 600,00 ha ano $^{-1}$ ) em diversas regiões analisadas (Cuiabá - MT, Aragarças - GO, Petrolina - PE, Porto Nacional - TO). Em outros casos, os retornos econômicos foram pouco atraentes aos investidores ( $\mathrm{R}$-100,00 a 300,00 ha $\mathrm{ano}^{-1}$ ), (Campo grande - MS, Uberaba - MG, Rio Verde - GO, Piracicaba - SP), o que justifica a utilização da metodologia desenvolvida no processo de tomada de decisão do pecuarista, visando minimizar os riscos de insucesso nesse tipo de empreendimento. 


\title{
PASTURE IRRIGATION ECONOMIC VIABILITY FOR TANZANIA GRASS IN DIFFERENT BRAZILIAN REGIONS
}

\author{
Author: Valter Dantas Pinheiro \\ Adviser: Prof. Dr. Rubens Duarte Coelho
}

\section{SUMMARY}

The seasonality in forage production is one of the most important factors related to low profit indexes concerning the national beef cattle raising activities. In the last 5 years, some cattle breeders captalized in Goiás and Mato Grosso do Sul states, have set up nearly 120 irrigation machines (center pivot), totalizing around 10.000 ha of irrigated pastures for beef cattle in Central Brazil. The economic results achieved so far, have shown to be variable and unpredictable, as while some cattle breeders have already failed to carry on these projects, others have obtained surprising profitability for this activity. The purpose of this study is to present a methodology for the economic analysis of pasture irrigation viability in different Brazilian regions, estimating the productivity of irrigated Tanzania grass through a mathematical model adjusted by means of a field experiment carried out in Piracicaba - SP, based on the local monthly availability of photo-thermal units (temperature and photoperiod) for different nitrogen fertilization levels. In the present study, the parameters of the Gompertz function were adjusted for the different nitrogen doses analyzed, being the best adjustments observed for the highest nitrogen doses: 275, 756 and $2079 \mathrm{~kg} \mathrm{~N} \mathrm{ha}^{-1}$ year $^{-1}$, with $\mathrm{r}^{2}=0,9650 ; 0,8938$ and 0,9784 respectively. Yet, for the lowest nitrogen doses studied, 0 and $100 \mathrm{~kg} \mathrm{~N}$ $\mathrm{ha}^{-1}$ year $^{-1}$, the adjusted equation presented moderate precision for the production estimative, $r^{2}=0,7047$ and 0,7112 , respectively. The simulations carried out for the 
center pivot irrigation of tanzania grass pastures in the Brazilian territory, presented interesting economic responses ( $\mathrm{R} \$ 400,00$ to 600,00 ha year $^{-1}$ ) in several regions analyzed (Cuiabá - MT, Aragarças - GO, Petrolina - PE, Porto Nacional - TO). In other cases, the profit was little attractive to investors (R $\$-100,00$ to 300,00 ha year ${ }^{-1}$ ), (Campo Grande - MS, Uberaba - MG and Rio Verde - GO, Piracicaba - SP), justifying the use of the developed methodology in the cattle raiser's decision making process, aiming to minimizing the risks of failure in this business. 


\section{INTRODUÇÃO}

As pastagens brasileiras são cultivadas em áreas sujeitas às variações climáticas, de temperatura, de radiação solar e de índice pluviométrico; a produtividade, na maioria das gramíneas tropicais diminui quando algum desses fatores se torna limitante. A baixa produtividade das plantas forrageiras durante o período de seca é uma dos principais causas da baixa produtividade dos rebanhos criados a pasto no Brasil.

A estacionalidade da produção de forragens é um fator de grande importância, porque se relaciona com os baixos índices de unidade animal por área. Em várias regiões do Brasil, modelos matemáticos para estimar a produção de forragem podem contribuir para o aumento do número de unidade animal por hectare; é necessária uma avaliação econômica bem detalhada, visando a minimizar a estacionalidade da produção da pastagem, com o uso da irrigação e da adubação nitrogenada.

O estudo de plantas forrageiras no Brasil é de fundamental importância, pois a pecuária apresenta-se como uma das principais atividades econômicas no país. A ocorrência da estacionalidade climática provoca prejuízos a essa pecuária extensiva, pois, em certas regiões do país, ocorre uma acentuada redução na produção forrageira, durante o período de inverno, ocasionando efeitos indesejáveis na rentabilidade econômica desses empreendimentos.

Períodos de deficiência hídrica, assim como condições de luminosidade e temperatura desfavoráveis no período de inverno podem ser considerados os fatores limitantes, do ponto de vista climático, para o desenvolvimento de gramíneas forrageiras em ambientes de clima tropical.

Chandler (1973), estudando doses de nitrogênio variando de 0 a $1792 \mathrm{~kg} \mathrm{~N} \mathrm{ha}^{-1}$, com Panicum maximum e outros seis tipos de forragens, encontrou expressivas respostas 
à adubação, até o nível máximo estudado. A disponibilidade imediata de nitrogênio após o corte maximiza o perfilhamento e aumenta o índice de área foliar (IAF), possibilitando um estande puro, o que favorece as gramíneas, em detrimento das invasoras (Corsi, 1986).

Utilizando-se dados climatológicos locais, como temperatura do ar e fotoperíodo, facilmente disponíveis em diferentes regiões do Brasil, é possível calcular o parâmetro unidade fototérmica disponível na propriedade rural, o que permite estimar-se com maior precisão, a produção do capim tanzânia de matéria seca, ao longo do ano, irrigado e adubado. A precisão é maior pelo parâmetro graus-dia, empregado em diversos modelos para a estimativa de produções, a qual se baseia apenas na temperatura do ar.

O conceito de "unidade fototérmica", proposto por Villa Nova et al. (1999), mostrou-se preciso na estimativa da produção total de matéria seca de capim elefante em condições variáveis de deficiência hídrica no solo. Tal tipo de estimativa é indispensável para o planejamento e a avaliação do sistema de produção animal a pasto, levando-se em conta a crescente utilização de equipamentos de irrigação do tipo pivô central em pastagens, nas regiões de clima quente e seco do Brasil Central.

O objetivo desta pesquisa é desenvolver uma análise econômica aprofundada sobre a viabilidade de irrigação de pastagens em diferentes regiões do Brasil, estimandose a produtividade do capim tanzânia pela disponibilidade de unidades fototérmicas local ao longo do ano, com base em um modelo matemático de produtividade, ajustado em um experimento de campo conduzido em Piracicaba-SP, para diferentes níveis de adubação nitrogenada. 


\section{REVISÃO DE LITERATURA}

\subsection{Irrigação e estacionalidade de produção}

As forrageiras do gênero Panicum, pertencentes à família Gramínea e à tribo Paniceae, apresentam cerca de 81 gêneros e mais de 1460 espécies. O capim Panicum maximum Jacq., de origem africana, foi, na década de 70, a gramínea mais difundida no Brasil (Carriel et al., 1979). O capim Panicum maximum é uma cultura perene, formadora de touceiras, podendo apresentar o sistema radicular profundo, de 45 a 150 cm (Molinari, 1952); a altura de planta entre 60 e $200 \mathrm{~cm}$; os limbos foliares verdeescuros, com $35 \mathrm{~mm}$ de largura, terminando em pontas finas; as panículas entre 12 e 40 $\mathrm{cm}$ de altura e as espiguetas abertas, entre 3 e $3,5 \mathrm{~mm}$. de longitude (Skerman \& Riveros, 1992).

A irrigação tem por objetivo proporcionar uma umidade no solo de fácil disponibilidade às plantas, para que os vegetais tenham condições de um maior desenvolvimento vegetativo e, conseqüentemente, uma elevada produção de massa. $\mathrm{O}$ capim tanzânia (Panicum maximum Jacq cv. tanzânia) apresenta uma variação estacional de produção, compreendendo dois períodos distintos na região Sudeste do Brasil: 1) período de inverno, nos meses de maio, junho, julho, agosto e setembro, e 2) período de verão, nos meses restantes do ano.

A pluviosidade afeta diretamente o crescimento das plantas e a produção de matéria seca nas regiões tropicais e subtropicais, sendo que as gramíneas do gênero Panicum intolerantes a inundações do terreno, apresentam maiores concentrações em regiões cujos índices pluviométricos anuais se apresentam superiores a $760 \mathrm{~mm}$ (Rocha, 
1991) e 1000 mm (Skerman \& Riveros, 1992). Para o gênero Panicum, McCosker \& Teitzel (1975) atribuíram uma exigência média anual de $1300 \mathrm{~mm}$.

Sistemas de pastejo rotacionados, irrigados por pivô central, em forrageiras tropicais estão sendo utilizados na tentativa de minimizar o efeito do déficit hídrico e conseqüentemente diminuir a oscilação na produtividade, provocada por veranicos, em épocas quando a temperatura não é limitante para seu crescimento (Xavier et al., 2001).

Pedreira (1981), no Estado de São Paulo, trabalhando com quatro espécies forrageiras, entre as quais o capim colonião (Panicum maximum Jacq.), dividiu o ano em duas estações: "verão" - meados de outubro a meados de abril; "inverno" - meados de abril a meados de outubro. Verificou que cerca de $90 \%$ da produção anual de matéria seca estava concentrada no "verão". Ghelfi (1972), trabalhando com capim elefante napier, obteve $76 \%$ da produção anual de matéria seca no período de "verão" e 24 \% no período de "inverno".

Recentemente, um grande número de cultivares da espécie Panicum maximum foi lançado comercialmente por diversos órgãos de pesquisa do Brasil; algumas delas apresentaram expressivas áreas implantadas. Apesar do sucesso na seleção de materiais genéticos, cujas produções de matéria seca são maiores do que as obtidas pela variedade Colonião, ainda não se conseguiu resolver o problema da estacionalidade de produção dessas plantas forrageiras (Jank et al., 1994).

\subsection{Balanço hídrico climatológico}

A metodologia de quantificação do balanço hídrico climatológico no solo, proposta por Thornthwaite \& Mather (1955), é uma das várias maneiras de se monitorar a variação do armazenamento de água do solo. O monitoramento realiza-se através da contabilização do suprimento natural de água ao solo (chuva - P) e da demanda atmosférica (evapotranspiração potencial - ETP), calcula-se um nível máximo de armazenamento ou a capacidade de água disponível (CAD), apropriados ao tipo de planta cultivada. O balanço hídrico fornece estimativas da evapotranspiração real (ETR), da deficiência hídrica (DEF), do excedente hídrico (EXC) e do armazenamento de água 
do solo (ARM). Essa contabilização pode ser feita tanto na escala diária como em escalas maiores, como a mensal, utilizando-se valores médios de vários anos (normal climatológica). O balanço hídrico assim calculado torna-se um indicador climatológico da disponibilidade hídrica no solo em uma determinada região, para uma dada cultura (Sentelhas \& Rolim, 1999).

Na elaboração do balanço hídrico climatológico, o primeiro passo é atribuir um valor de $\mathrm{CAD}$, correspondente ao intervalo de umidade do solo entre a capacidade de campo (CC) e o ponto de murcha permanente (PMP).

Como o balanço hídrico, segundo Thornthwaite \& Mather (1955), normalmente é utilizado para fins de caracterização da disponibilidade hídrica de uma região em bases climatológicas e comparativas, na prática muitas vezes a seleção da CAD é feita mais em função do tipo de cultura, ao qual se quer aplicá-lo, do que do tipo de solo. Justificase isso comparando um solo arenoso e um argiloso: se, no primeiro, o valor de (CC \% PMP \%) é menor, no segundo, a profundidade efetiva do sistema radicular (Z) para uma dada cultura é menor no solo argiloso, de maneira que há uma compensação, tornando a CAD aproximadamente igual para os dois tipos de solo. Assim, independentemente do tipo de solo, podem-se adotar valores de CAD menores, como por exemplo: para hortaliças (25 a $50 \mathrm{~mm})$, para culturas anuais $(75$ a $100 \mathrm{~mm})$, para culturas perenes (100 a $125 \mathrm{~mm}$ ) e para espécies florestais (150 a $300 \mathrm{~mm}$ ) (Sentelhas et al., 1999).

$\mathrm{O}$ rendimento máximo da cultura $(\mathrm{PP})$, em uma dada região, depende das condições climáticas, podendo ser estimado para diferentes localidades, através de relações que expressam a eficiência da cultura na conversão de energia solar em produção de matéria seca. Isso permite a quantificação do potencial produtivo de diferentes áreas, indicando, desse modo, as mais apropriadas para a produção de determinada cultura, servindo como estimativa da produtividade real (PR). Quando o suprimento de água não atende às necessidades hídricas da cultura, a evapotranspiração real (ETR) torna-se inferior à evapotranspiração da cultura (Etc); desenvolve-se então, um estresse hídrico na planta, com o fechamento parcial ou total dos estômatos, reduzindo-se a fotossíntese e, conseqüentemente, a produtividade da planta. O efeito do suprimento de água sobre a produtividade de uma cultura pode ser quantificado por um 
fator de resposta da cultura $(\mathrm{ky})$, que relaciona a queda relativa de rendimento (1 $\mathrm{PR} / \mathrm{PP})$ com o déficit relativo de evapotranspiração $(1$ - ETR/Etc) (Doorenbos \& Kassam, 1994).

\subsection{Temperatura e fotoperíodo}

Os ciclos de crescimento das gramíneas são influenciados por vários fatores climáticos, como a temperatura ambiente, a disponibilidade hídrica e a luminosidade, que determinam todo o desenvolvimento, em função do potencial genético da planta.

Sob condições de temperaturas médias anuais de verão superiores a $29{ }^{\circ} \mathrm{C}$ e de inverno acima de $15{ }^{\circ} \mathrm{C}$, características das regiões tropicais e subtropicais, o fator temperatura perde importância e as condições hídricas assumem papel preponderante na fenologia das plantas. Entretanto, em regiões cujas temperaturas médias anuais de verão são de $10{ }^{\circ} \mathrm{C}$ a $20{ }^{\circ} \mathrm{C}$ e de inverno entre $5{ }^{\circ} \mathrm{C}$ e $15{ }^{\circ} \mathrm{C}$, a temperatura exerce papel tão importante quanto a umidade no solo (Burkart, 1975).

Como a estacionalidade da radiação solar, da temperatura e da chuva determina basicamente a estacionalidade da produção das forrageiras no Brasil Central, a produção de gramíneas não é uniforme ao longo do ano, sendo abundante na primavera e no verão e escassa no outono e no inverno (Soto, 1981).

Em estudos de estacionalidade da produção de gramíneas tropicais, observou-se que a máxima produção de matéria seca não ocorre nos meses de temperatura do ar mais elevada, mas sim no início do verão (Pedreira \& Mattos, 1981), mesmo com a irrigação (Ghelfi, 1972), indicando que modelos baseados unicamente em soma térmica seriam inadequados para a previsão da produção. O modelo descrito visa a estabelecer o potencial de produção de forragem, na ausência de déficit hídrico, a partir de dados regionais de temperatura do ar e do fotoperíodo.

Segundo Weigand ${ }^{1}$ pode-se perceber que outros fatores, além da água e da adubação, têm grande influência na queda de produção das forragens na seca. Esses

\footnotetext{
${ }^{1}$ WEIGAND, R. Relatório de estágio supervisionado: irrigação de pastagens, Piracicaba: ESALQ., 1997. 24p.
} 
fatores seriam as menores temperaturas de inverno e o menor fotoperíodo. Além disso, não está bem estabelecida qual a participação de cada um desses fatores na menor produção de forragem no inverno. Como o metabolismo da planta varia na razão direta da temperatura, quanto mais intensivo o frio, menor o crescimento. Para as forrageiras tropicais, por exemplo, ocorre que, quando ela é menor que $15{ }^{\circ} \mathrm{C}$, o crescimento praticamente cessa; dai a temperatura ter sempre sido considerada o fator determinante da menor produção. Entretanto tem-se verificado que a participação do fotoperíodo também é determinante.

A taxa de crescimento do gênero Panicum apresenta-se extremamente baixa sob temperaturas médias inferiores a $15{ }^{\circ} \mathrm{C}$ (Cooper \& Tainton, 1968; McWilliam, 1978; Gomide, 1994) e entre $5,5{ }^{\circ} \mathrm{C}$ e $14{ }^{\circ} \mathrm{C}$ (Skerman \& Riveros, 1992).

A drástica redução na taxa de fotossíntese e na elongação foliar dos perfilhos (Cooper \& Tainton, 1968), em plantas do gênero Panicum submetidas a temperaturas inferiores a $15{ }^{\circ} \mathrm{C}$, determina a ocorrência da estacionalidade da produção (McCosker \& Teitzel, 1975; Rolim, 1980) em diversas regiões produtoras.

\subsection{Adubação e índice de área foliar (IAF)}

Pereira et al. (1966), estudando o efeito da irrigação e da adubação em 13 gramíneas na época seca, em duas regiões do Estado de Minas Gerais, concluíram que a adubação sem irrigação aumentou a produção de massa verde em 56 \% numa localidade, enquanto, na outra, não houve diferença entre os tratamentos. Em ambos os locais as produções aumentaram em 62 e $72 \%$, como conseqüência da irrigação sem adubação. A interação entre irrigação e adubação aumentou a produção em 209 e 176 \%, em cada uma das duas regiões.

O nitrogênio é, sem dúvida, um dos elementos mais ausentes no solo, embora desempenhe papel fundamental na modulação das respostas das plantas às adubações. A maior eficiência em uso, assim como as melhores respostas em termos de produção, somente ocorrerão quando os demais nutrientes se encontrarem em equilíbrio na solução do solo, de forma a gerar um ambiente ótimo para os processos de absorção por parte da 
planta. Após a eliminação do meristema apical, pelo corte ou pelo pastejo, a produção de matéria seca é determinada pela expansão das folhas, a qual depende das condições climáticas e da disponibilidade de nitrogênio, justificando-se desse modo, a adubação com nitrogênio imediatamente após o corte (Corsi \& Nussio, 1993).

O nível de fertilidade do solo para a exploração de pastagem é um dos principais fatores que interferem no nível de produção e na qualidade da forragem. A correção e o ajuste nos níveis dos nutrientes do solo, tanto macro quanto microelementos, assume importância fundamental e deve ser prática indispensável para a exploração racional das plantas forrageiras (Corsi \& Nussio, 1993).

Turck \& White (1954), estudando os métodos de irrigação em gramíneas de clima tropical, concluíram que o uso da irrigação provocou maior retirada de nutrientes do solo por parte do vegetal, fazendo-se necessárias por isso, adubações anuais de restituição, principalmente de fósforo. Segundo Ellis (1950), a aplicação de nitrogênio resultou em aumento de rendimento dos capins elefante, colonião e guatemala; porém o efeito do potássio e do fósforo variou com o tipo de solo. Nenhum desses elementos afetou o conteúdo de proteína bruta dos capins citados.

A elevação, até $360 \mathrm{~kg} \mathrm{~N} \mathrm{ha}^{-1}$ ano $^{-1}$, dos níveis de adubação, aumentou a produção de matéria seca e o índice de área foliar (IAF) das gramíneas, favorecendo mais o cv.Tifton-85, enquanto a irrigação isoladamente não influenciou as variáveis estudadas (Marcelino et al., 2001). Entretanto Nabinger (1997) relata redução do IAF em plantas submetidas a déficit hídrico.

O IAF das gramíneas aumentou $(\mathrm{P}<0,01)$ com a elevação nos níveis de nitrogênio. O IAF variou, respectivamente, de 4,80 a 6,79 no cv. Tifton 85, e de 8,58 a 10,97 no cv. Marandu, quando comparado ao da testemunha com $360 \mathrm{~kg} \mathrm{~N} \mathrm{ha}^{-1} \mathrm{ano}^{-1}$. Provavelmente, isso se deva ao favorecimento do $\mathrm{N}$ na produção de folhas novas. $\mathrm{O}$ nitrogênio favorece a formação da parte aérea, resultando em maior área fotossintetizante, melhorando a eficiência fotossintética e a redistribuição prioritária de carbono na planta (Nabinger, 1997). 


\subsection{Modelos matemáticos}

Uma característica básica dos sistemas agrícolas, que os diferenciam de outros sistemas, é o fato de organismos vivos, animais e plantas, estarem diretamente relacionados ao processo produtivo. Isso introduz um grau maior de incerteza nesses sistemas, pois o número de fatores aleatórios torna-se elevado. Diversas formas de descrição e de avaliação desses sistemas, através de modelos matemáticos, têm sido apresentadas na literatura, variando de modelos que constituem simples equações de regressão a complexos modelos de simulação (Tatizana, 1995).

Embora a construção de modelos, via programação matemática, tenha alcançado considerável progresso, as teorias de importantes processos biológicos e econômicos ainda não são perfeitamente compreendidas do ponto de vista teórico, o que impossibilitam que sejam incorporadas aos modelos desenvolvidos. A exata solução de um problema, inadequadamente definido, possui aplicação limitada (Dent \& Anderson, 1971). Muitos de tais modelos retratam partes específicas da realidade, ou estabelecem simplificações, a fim de tornar viável o processo analítico. Na maior parte dos casos, o propósito é a determinação de um ponto ótimo num sistema agrícola.

Nesse contexto, o desenvolvimento de modelos matemáticos pode facilitar o manejo, o controle e a análise de decisão na propriedade, estabelecendo-se critérios técnicos na implantação e na condução do sistema de pasto irrigado, para sua viabilidade econômica.

A porcentagem do acúmulo de forragem, em função da temperatura do ar e do fotoperíodo, depende de seu estádio de desenvolvimento. O estudo do crescimento de gramíneas forrageiras tem demonstrado que elas apresentam, geralmente, uma curva assintótica de crescimento, que, muitas vezes, toma a forma de uma sigmóide, quando submetidas a cortes drásticos. Assim, espera-se que a resposta da planta à temperatura do ar e ao fotoperíodo não seja sempre a mesma durante seu desenvolvimento e, portanto, que a função de produção em função da unidade fototérmica $(P=f(U F))$ não seja linear eq. (1) (Villa Nova et al. 1999). 


$$
P=\frac{12.61}{1+e^{2.85-8.133 \times 10^{-5} U F}}
$$

em que $P$ é a produção de matéria seca ( $\mathrm{t} \mathrm{ha}^{-1}$ no período de $\mathrm{n}$ dias); $U F$ é a unidade fototérmica correspondente ao período de $\mathrm{n}$ dias.

Gennville (1984) descreveu, em modelo de simulação de produção de pastagem desenvolvido na EMBRAPA-CNPGC, que o crescimento ocorre em função da umidade disponível no solo, da radiação solar, da temperatura, da fertilização com fósforo e da biomassa aérea fotossintetizante. $\mathrm{O}$ autor concluiu que a água e a biomassa fotossintetizante apresentam maior efeito na produção de pastagem, em comparação aos demais fatores.

Overman et al. (1990) ajustaram um modelo matemático, eq. (2), que relaciona o rendimento de matéria seca ao nitrogênio aplicado em gramíneas da espécie Paspalum notatum. O propósito desse trabalho foi determinar o efeito da água disponível e do intervalo de corte nos parâmetros da equação para Cynodon dactylon e Paspalum notatum.

$$
y=\frac{A}{1+e^{b-c N}}
$$

em que $y$ é o rendimento anual de matéria seca estimada, $\mathrm{Mg} \mathrm{ha}^{-1} ; N$ é o nitrogênio aplicado, $\mathrm{kg} \mathrm{ha}^{-1} ; A$ é o rendimento anual máximo, $\mathrm{Mg} \mathrm{ha}^{-1} ; b$ é o intercepto com o eixo y; $c$ é o coeficiente de resposta, ha $\mathrm{kg}^{-1}$.

Os parâmetros $A, b$ e $c$ são estimados por regressão não-linear, usando-se o processo de Newton-Raphson.

A forma mais usual para a simulação de produção de pastagem tem sido o uso de equações de regressão, que ajustam resultados experimentais aplicados em modelos generalistas. Essas equações empíricas freqüentemente produzirão resultados imprecisos, em condições diferentes daquelas em que foram estabelecidas. Por outro lado, a consideração de médias de produção de pastagem, ou simplesmente da 
capacidade de suporte de um determinado pasto, torna a análise global limitada, desconsiderando uma importante fonte de variação que é a produção da pastagem. Existe a necessidade do desenvolvimento mais apurado de equações básicas que permitam sua utilização em modelos generalistas de produção de pastagens (Tatizana, 1995).

Considerando o fato de que a tecnologia disponível não está sendo adotada de forma eficiente na produção de carne bovina no Brasil, e que grande parte dos trabalhos da pesquisa zootécnica estão dissociados da análise econômica, a formulação de modelos globais de simulação pode ser uma ferramenta importante para pesquisadores e produtores de gado. Embora existam modelos generalistas de produção de gado de corte, as particularidades do sistema de produção brasileiro e a falta de dados para a alimentação desses modelos generalistas justificam o desenvolvimento de um modelo conceitual que se adapte às condições nacionais.

\subsection{Ganho de peso em bovinos e conversão alimentar}

O aumento de produtividade é uma necessidade prioritária nos dias de hoje, imposta pelo mercado consumidor e pela globalização. A pecuária brasileira, tanto de corte como de leite, vem sofrendo um processo de modernização, com o objetivo de aumentar a produtividade. Para que isso se torne possível, estão realizando-se trabalhos para melhorar o manejo e a composição genética dos rebanhos. Isso se faz com o intuito de se obterem características zootécnicas desejáveis, de modo que a produtividade e a precocidade se pronunciem, de preferência nos períodos denominados, ano e sobreano, nos quais o animal apresenta rápidos crescimento e ganho de peso, o que definem a curva de crescimento dos animais.

O desenvolvimento corporal e o ganho de peso não são as únicas características utilizadas na seleção de indivíduos de raças, mas constituem fatores importantes nesse processo seletivo. Tais métodos de seleção têm sido utilizados por instituições, empresas privadas ou mesmo criadores, visando ao emprego de reprodutores geneticamente superiores. 
O ganho de peso em bovinos de corte constitui a principal meta a alcançar em uma exploração racional. $\mathrm{O}$ crescimento de bezerros, do nascimento à desmama (7-8 meses), representa 25 a $35 \%$ do peso final, sendo o restante obtido nos meses antecedentes à idade de abate. Entre fatores que interferem no crescimento em gado de corte até a desmama, destacam-se: crescimento pré-natal, grupo racial, sexo, idade da mãe, ano e mês de nascimento, crescimento pré-desmame, efeito da habilidade materna e nível nutricional dos bezerros (Peixoto, 1993).

Andrade (1983), enumera os fatores que afetam o ganho de peso como um todo, classificando-os como ligados ao animal (raça, idade, peso vivo e sexo), à nutrição e à alimentação (tipo de volumoso, teores energético e protéico, relação concentrado: volumoso, processamento, uniformidade, freqüência de alimentação e palatabilidade), ao manejo (disponibilidade de cocho, uniformidade do lote, sistema a pasto ou confinamento, uso de anabolizantes, controle sanitário) e, finalmente, aos fatores climáticos (luminosidade, temperatura e umidade relativa do ar).

Razook (1988) cita que a seleção direta para crescimento, dentro de rebanhos, particularmente para pesos nas várias idades, promove ganho genético na característica submetida à seleção direta, bem como em características correlacionadas (ganhos, pesos em diversas idades, conformação, carcaça e conversão). A seleção direta para pesos finais pós-desmame promove maior desenvolvimento até a idade adulta dos animais. Já a seleção direta para conformação é ineficiente, provavelmente devido à subjetividade do caráter. Provavelmente a seleção indireta com atenção a caracteres de crescimento, tais como peso, promove razoável progresso na conformação dos animais, o que se reflete positivamente na comercialização.

Em bovinos, a adoção de cruzamentos industriais ou a utilização de "raças sintéticas“, formadas a partir de animais mestiços, permite elevar o potencial de ganho, conforme demonstrado por Pereira et al. (1974), que obtiveram ganhos médios diários de 1,021 kg e 0,793 kg, para animais F1 Suíça-parda-Guzerá e Nelore, respectivamente.

Santana \& Caldas (1973) realizaram trabalho com mestiços holandeses durante 112 dias, alimentando-os com capim colonião, melaço e uréia, conseguindo registrar médias diárias de ganho de peso de até 0,964 kg. Velloso \& Figueiredo (1970/71) 
registraram consumos de matéria seca (MS) para bovinos da raça Nelore com peso médio de $370 \mathrm{~kg}$, variando entre 2,01 e 2,38 kg/100 kg de peso vivo (PV).

Num experimento comparativo de animais 1/2 sangue Holandês x Zebu (H.Z.) e outros da raça Gir, Vilela et al. (1973) não detectaram diferenças estatísticas significativas quanto aos ganhos em peso, com médias individuais diárias variando entre 0,623 e 0,841 kg. Os consumos de MS oscilaram de 2,38 a 2,60 kg/100 kg de PV, para os animais da raça Gir, e de 2,73 e 3,23 kg/100 kg PV, para os 1/2 sangue H.Z., diariamente. Para animais manejados a pasto, o consumo de matéria seca é, em geral, considerado de 2,1 \% PV, isso devido a sua difícil avaliação (Lanna et al., 2001).

Ledger et al. (1970), ao fornecerem quantidades fixas de fenos, de Cynodom e de alfafa e concentrado à vontade, para novilhos Bos indicus, Bos taurus e mestiços, verificaram melhor conversão alimentar nos taurinos que nos zebuínos; os mestiços ocuparam posição intermediária; as raças de origem européia, submetidas a um processo de seleção mais intenso, tiveram maior capacidade de ingestão de alimentos e melhor conversão alimentar.

Maior consumo alimentar por $100 \mathrm{~kg}$ de peso vivo em Bos Taurus e seus mestiços foram relatados por Velloso et al. (1975), que verificaram consumo alimentar de 2,33 e 2,50 kg por 100 de peso vivo em animais Nelore e Pitangueiras, respectivamente.

Segundo Souza et al. (2001), o consumo médio de matéria seca expresso em porcentagem do peso vivo apresentou resposta quadrática, estimando-se valor máximo de 2,35 \% para rações contendo 28,68 \% de silagem de sorgo. Os consumos médios foram superiores aos encontrados por Neumann et al. (1999), 2,17 \% PV, em novilhos confinados recebendo silagem de sorgo do mesmo híbrido, com relação volumoso : concentrado de 65:35.

As variações observadas no comportamento de animais de diferentes grupos genéticos, nos experimentos citados, resultam das diferenças no nível nutricional e do manejo empregado. Por isso, deve-se ter o máximo de cautela na escolha dos tipos de animais em que se vai trabalhar no sistema de pasto irrigado, principalmente quanto ao 
fator peso de entrada e de saída dos mesmos, já que animais acima de $380 \mathrm{~kg}$ de PV apresentam um menor ganho diário de peso.

\subsection{Viabilidade econômica}

Para fins de análise econômica, o termo custo significa a compensação que os proprietários dos fatores de produção, utilizados por uma empresa para produzir determinado bem, devem receber para que continuem fornecendo esses fatores à mesma (Hoffmann et al., 1987). Os custos são classificados em fixos, que não se alteram com a quantidade produzida, e variáveis, que variam de acordo com o nível de produção da empresa. Para um sistema de pastejo rotacionado, irrigado por pivô central, são considerados como custos fixos principalmente a depreciação dos componentes do sistema e a remuneração de capital investido; já como custos variáveis, os dispêndios com a energia, a adubação, os reparos dos equipamentos e a infra-estrutura utilizados na operação do sistema.

A depreciação é o custo necessário para substituir os bens de capital de longa duração, quando eles se tornam inutilizáveis, em decorrência do desgaste físico, ou perdem valor com o passar dos anos, devido às inovações tecnológicas e/ou à capacidade de gerar receitas (Frizzone, 1999).

O sistema de pastejo rotacionado, sob pivô central, tem gerado muita polêmica por parte dos pesquisadores e dos produtores de maneira geral, pois é um sistema que requer um alto investimento inicial, demandando todo um estudo de potencial produtivo da região em questão, além de uma análise de viabilidade econômica da pastagem irrigada e adubada. A produtividade de carne, nas fazendas que exploram pastagem cultivada, fica em torno de 150 e $180 \mathrm{~kg} \mathrm{ha}^{-1} \mathrm{ano}^{-1}$ de peso vivo (PV) ou 75 a $90 \mathrm{~kg}$ de carcaça ha ${ }^{-1}$ ano $^{-1}$, enquanto se podem encontrar, na literatura, produções acima de 900 $\mathrm{kg} \mathrm{ha}^{-1} \mathrm{ano}^{-1}$ de PV (Aguiar et al., 2000), sinalizando que a produtividade pode ser aumentada em pelo menos cinco vezes.

Para o cálculo da remuneração do capital investido, a taxa de juros a considerar varia de caso para caso, de acordo com o que se passa no respectivo mercado financeiro. 
Para a determinação do valor do seguro, das taxas e dos impostos, é possível utilizar os procedimentos constantes nas normas tributárias (Turra, 1990). Os encargos pertinentes aos seguros e às taxas, geralmente, são reduzidos, quando comparados a outras despesas. Por isso, verificou-se que, em algumas situações, eles são considerados, enquanto, em outras, não (Filho \& Gonzaga, 1991; Melo, 1993; Turra, 1990; Brasil, 1996).

Os custos operacionais e de manutenção (custos variáveis) compreendem, fundamentalmente, os dispêndios realizados com cerca elétrica, mão-de-obra, reparos dos equipamentos e infra-estrutura utilizada na operação do sistema de pastagem irrigada, além da energia e dos adubos necessários. Acrescenta-se que, para avaliar os custos variáveis das "pastagem irrigadas", são necessários os custos com adubos, corretivos, defensivos, juros sobre o capital de giro. Os custos com energia e adubação nitrogenada, na maioria das vezes, constituem os principais itens do custo variável. Turra (1990), em seu trabalho de análise de custos de produção na agricultura brasileira, dispõe que podem ser consideradas como variáveis as despesas com equipamentos (energia e manutenção), implementos, animais de trabalho, manutenção de benfeitorias, mão-de-obra temporária, insumos, transporte externo, vacinas, suplementação mineral, assistência técnica, custos financeiros e despesas gerais.

Como já foi mencionado anteriormente, dentre os custos de operação (variáveis) de um sistema de irrigação, o consumo de energia destaca-se como um dos principais componentes (Melo, 1993; Frizzone et al., 1994; Bonomo et al., 1999). A quantidade de energia necessária para transportar a água do local de captação à área a ser irrigada é muito variável. O consumo total depende da energia para fornecer a quantidade de água demandada na área irrigada, da quantidade de água a ser aplicada, da energia hidráulica exigida pelo sistema de irrigação e da eficiência total do sistema de bombeamento (Scaloppi, 1985). Com relação aos recentes problemas energéticos do país, Portugal (2001), de acordo com dados da Confederação Nacional da Agricultura (CNA), o consumo de energia elétrica no setor agrícola é de apenas $4 \%$ de todo o consumo do país.

Outro ponto a considerar é a discordância entre os pesquisadores sobre a viabilidade econômica da adubação de pastagens para a produção de carne, como se vê 
em Gomide (1986), que concluiu: "aos preços atuais da carne e do nitrogênio (N) não é economicamente viável a aplicação de $\mathrm{N}$ em pastagens destinadas à engorda de novilhos". Nesse contexto, faz-se necessária a avaliação econômica das recomendações preconizadas pela pesquisa e pela extensão, embora não se tenham tornado rotina as análises econômicas nos trabalhos de pesquisas destinados a dar suporte para a tomada de decisão de consultores e produtores.

Os custos de implantação, de acordo com Frizzone et al. (1994) correspondem aos investimentos na aquisição e na implantação do sistema de irrigação, e são importantes na seleção e no uso de determinado sistema, pois são relativamente elevados e refletem-se diretamente nos custos operacionais do sistema utilizado. No entanto, um estudo de custo da irrigação não deve contemplar apenas os custos de implantação e de investimento, mas também outros custos fixos e variáveis (operacionais e manutenção), calculados por um ano e por unidade de área (Turra, 1990; Melo, 1993). Portanto devem-se avaliar os custos da "pastagem irrigada", e não somente os custos da irrigação.

Azevedo Filho (1988) fez, em seu trabalho, uma discussão considerando as limitações e as restrições sobre os principais critérios (indicadores) de avaliação de projetos, relacionados comumente na literatura. Os critérios discutidos no trabalho foram: relação benefício/custo, valor atual dos fluxos líquidos do projeto, "payback" simples - prazo de recuperação do capital, "payback" econômico e taxa interna de retorno.

Outro fator que, cada vez mais, está obrigando o pecuarista a intensificar sua produção é o encarecimento do preço da terra e, portanto, das pastagens. Nesse campo, vários fatores têm influência, como, por exemplo, o crescimento da renda populacional e a produção de grãos e outros produtos para a agroindústria, o que aumenta a pressão sobre os grandes centros, no sentido de destiná-los à produção de itens de maior valor agregado. Esses efeitos provocam um deslocamento da pecuária para locais distantes dos grandes centros, na procura de terras mais baratas, provocando aumento no custo dos insumos (fertilizantes, suplementos minerais e combustíveis), inviabilizando a produção (Peres, 1990). 
Na primavera e no início do verão, com temperaturas favoráveis ao crescimento da planta forrageira nas regiões mais quentes, a uniformização da produtividade das gramíneas tropicais é possível através do fornecimento de água em quantidade adequada à necessidade da planta, como ocorre nas regiões Centro-Oeste, Norte e Nordeste.

A eliminação do déficit hídrico através da irrigação constitui mais uma tecnologia que tenta uniformizar a produção das pastagens, no sentido de tornar profissional e competitiva a produção agrícola na bovinocultura de corte, possibilitando a engorda a pasto durante $\mathrm{o}$ ano todo.

$\mathrm{O}$ investimento inicial em um equipamento de irrigação é alto; dessa forma, torna-se obrigatória sua planificação criteriosa e consistente, a fim de conferir-lhe viabilidade econômica, e segurança e de minimizar impactos ambientais. Para responder à questão do risco envolvido e do nível de manejo para a otimização dos benefícios econômicos da irrigação, deve-se fazer um balanço hídrico no qual se estimem níveis de extração da capacidade de água disponível no solo e, em conseqüência, doses e turnos de irrigação. As diferentes frações de extração traduzem necessidades de irrigação diferenciadas, com respectivos níveis de probabilidade, que, por sua vez, representam respostas e custos de irrigação diferenciados. A irrigação por aspersão mecanizada, do tipo pivô central, vem sendo utilizada em sistema de pastejo rotacionado na bovinocultura de corte, principalmente nas regiões Sudeste e Centro-Oeste.

A eficiência na alocação de recursos produtivos constitui um objetivo natural de todo indivíduo ou empresa que se envolve na produção de determinado bem, a partir de um dado número de recursos. Contudo ocorre ineficiência, cuja causa essencial é o fator incerteza, que condiciona a tomada de decisão. Tal incerteza, por sua vez, é condicionada pelo volume de informações a que o indivíduo tem acesso durante o processo decisório (Arruda, 1982). Dessa forma, regulado pelo volume de informações disponíveis e, portanto, pelo grau de certeza sobre cada solução alternativa, o produtor pode optar.

Em todos os modelos de eficiência econômica, segundo Kindler (1988), o objetivo é a minimização dos custos de produção ou a maximização dos retornos econômicos líquidos, através do tempo, nos projetos de irrigação. A água nesses 
modelos é considerada análoga aos outros fatores de produção agrícola, como terra, sementes, fertilizantes, equipamentos e máquinas, capital e mão-de-obra. Assim, reconhece-se que a água tem um valor; porém como expressar e medir esse valor constituem outra questão e, na análise de seu uso, deve-se levar em conta todos os possíveis métodos de substituição e ajuste que deveriam ser apresentados quando a água se torna escassa e cara.

Bernuth (1983), pesquisando a quantidade de água aplicada num cultivo para a maximização econômica em condições de restrição de água, encontrou que a quantidade é uma função quadrática da lâmina de água utilizada pela cultura.

A atividade agrícola é afetada por um grande número de riscos e incertezas que têm origem nas oscilações ambientais. Além disso, existe o risco econômico ou de mercado, derivado de mudanças no preço dos produtos ou dos insumos e nas oportunidades de mercado. O nível de risco pode ser diminuído pela irrigação. Como via de regra, os sistemas de pastagens irrigadas não apresentam um manejo da irrigação tecnificado, o que poderá reduzir a produtividade potencial das plantas forrageiras, resultando em menor lotação ao longo do ano e ineficiência das adubações efetuadas. 


\section{MATERIAL E MÉTODOS}

O trabalho foi realizado no município de Piracicaba, localizado

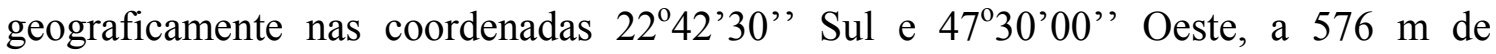
altitude, no campo experimental de irrigação na Fazenda Areão, vinculado ao Departamento de Engenharia Rural da Escola Superior de Agricultura "Luiz de Queiroz”, da Universidade de São Paulo. O clima, segundo a classificação de Koppen, é do tipo Cwa (Tropical úmido com três meses mais secos: junho, julho e agosto), com chuvas de verão. O solo da área é classificado como Podzólico Vermelho-Escuro, de textura franco-argilosa. A área experimental compreende uma superfície de $1125 \mathrm{~m}^{2}$, dividida em três blocos casualizados; cada bloco, por sua vez, foi dividido em parcelas com diferentes lâminas de irrigação, contendo subparcelas com diferentes doses de nitrogênio, totalizando 75 subparcelas de $15 \mathrm{~m}^{2}$, como mostrado nas Figuras 1 e 2 .

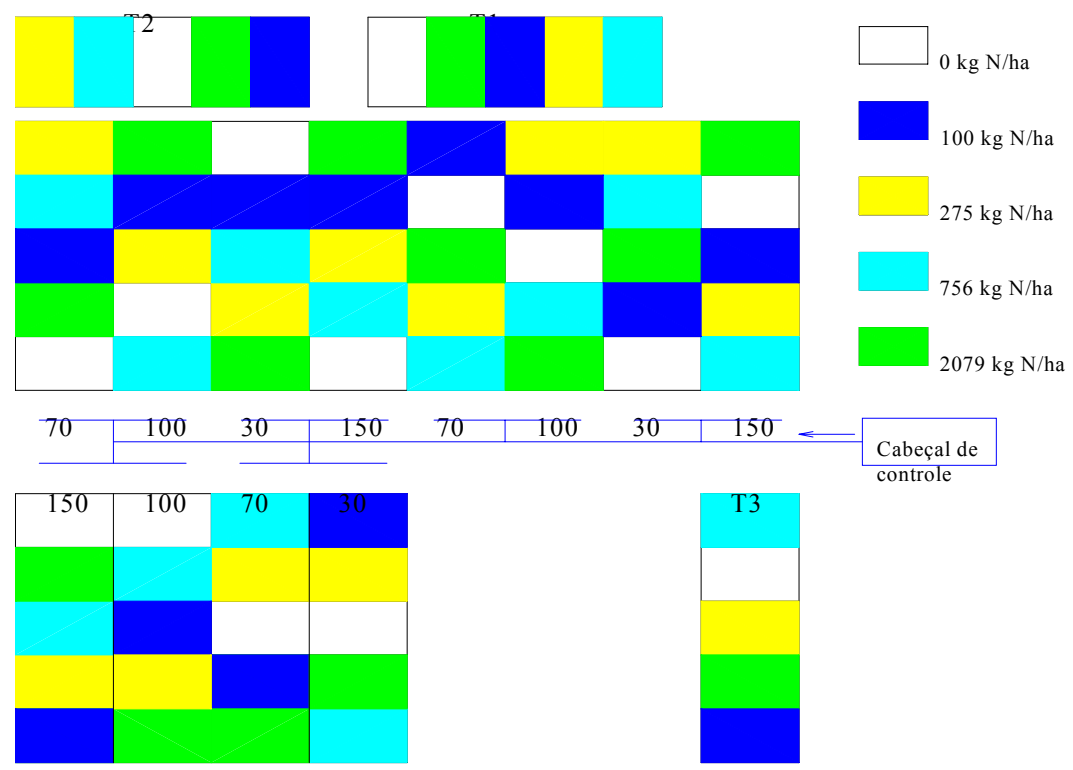

Figura 1 - Lay out da área do experimento na Fazenda Areão. 


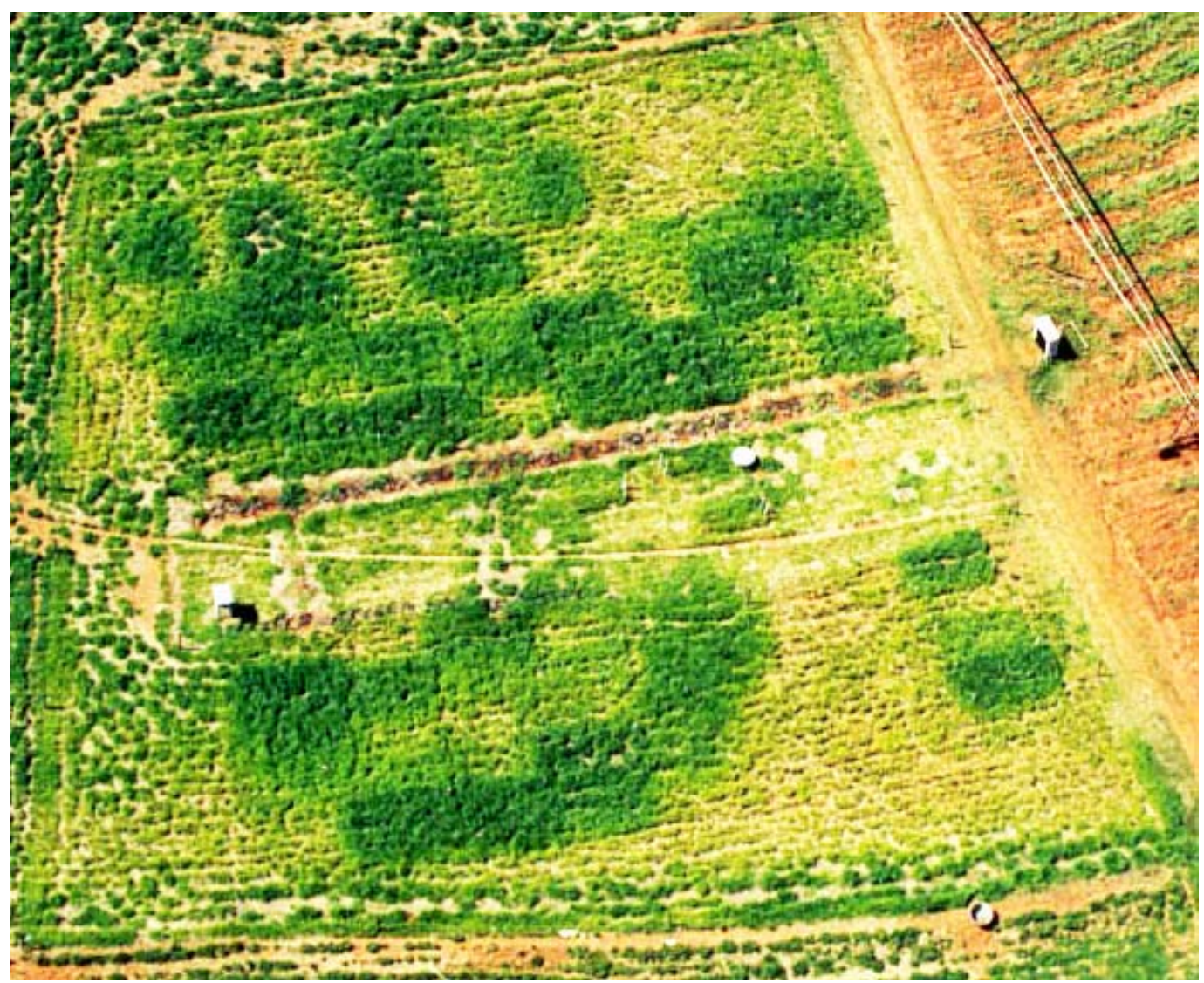

Figura 2 - Foto aérea do experimento na Fazenda Areão.

Os dados do trabalho foram coletados no experimento "Produtividade do capim tanzânia (Panicum maximum Jacq cv. tanzânia), em função da lâmina de irrigação e das doses de nitrogênio". Os cortes da forragem foram conduzidos a uma altura de corte de $25 \mathrm{~cm}$; no início do experimento, a área foi roçada, igualando-se todas as subparcelas; os cortes foram conduzidos com uma roçadeira motorizada, num retângulo de $2 \mathrm{~m}^{2}$, em intervalos de 36 dias. Após o corte, os bovinos pastejaram na área, nivelando as subparcelas na uma altura de resíduo de $25 \mathrm{~cm}$; com a saída dos animais, as subparcelas receberam as adubações com nitrogênio nas dosagens pré-determinadas, via fertirrigação com nitrato de amônia, dividindo-se as dosagens em 9 aplicações anuais, em função do número de cortes.

O manejo da irrigação foi realizado com o monitoramento do potencial de água no solo, através da tensiometria. Foram usados os tensiômetros de leitura com 
tensímetro de punção digital, instalados em 5 baterias de seis tensiômetros, nas profundidades de 0,$10 ; 0,20 ; 0,40 ; 0,60 ; 0,80$ e $1,00 \mathrm{~m}$, próximo às touceiras já formadas. Os dados meteorológicos diários (temperatura e precipitação) foram obtidos de uma mini estação meteorológica automática, instalada na área experimental.

\subsection{Condução da irrigação}

A água evapotranspirada nas parcelas experimentais, nos períodos com déficit hídrico no solo, foi resposta através da irrigação por gotejamento, com emissores autocompensantes distanciados de $50 \mathrm{~cm}$ nas linhas irrigadas, e de $70 \mathrm{~cm}$ entre linhas distribuídas sobre a superfície do solo. Cada gotejador apresenta uma vazão $2,0 \mathrm{~L} \mathrm{~h}^{-1}$, totalizando 7 linhas de mangueiras com gotejadores dentro das subparcelas.

As lâminas de irrigação nas parcelas foram baseadas em uma parcela de referência, mantida na capacidade de campo (padrão), através do monitoramento do potencial mátrico da solução do solo, via tensiometria digital de punção. As lâminas de irrigação do experimento foram porções de $0,30,70,100$ e $150 \%$ da lâmina de irrigação aplicada na parcela de referência. Totalizam-se, assim, 5 lâminas de irrigação utilizadas no experimento.

A freqüência da irrigação e a quantidade de água aplicada foram determinadas em função da variação do potencial mátrico acusado pelo tensiômetro. A irrigação teve início quando a média dos tensiômetros, posicionados a $20 \mathrm{~cm}$, registrar 0,2 a 0,3 bar, aplicando-se uma lâmina tal, que derrubasse as leituras dos tensiômetros para 0,1 bar.

\subsection{Produção de forragem}

Antes do corte das subparcelas, que representam uma área útil de $2 \mathrm{~m}^{2}$, foram feitos os cortes da forragem, a $25 \mathrm{~cm}$ do solo, usando-se uma roçadeira motorizada, conforme a recomendação de Garcia (1993). Após o corte, a forragem foi pesada no campo, com o objetivo de se determinar a matéria verde ou fresca. Desse material fresco, foram retiradas amostras representativas de cada subparcela (aproximadamente 
$0,5 \mathrm{~kg}$ de material verde), as quais foram identificadas e colocadas em saco de papel para procedimento de pré-secagem em estufa, com circulação forçada de ar a $65{ }^{\circ} \mathrm{C}$, por 72 horas, até peso seco constante. Os materiais, pesados em balança semi-analítica, foram moídos em moinho tipo Wiley, passados em peneira de $1 \mathrm{~mm}$ de diâmetro, e acondicionados em recipientes de vidro. A secagem definitiva foi obtida tomando-se sub-amostras de cinco gramas do material pré-seco e transferindo-as para estufa a 105 ${ }^{\circ} \mathrm{C}$, por 24 horas, e procedendo-se à pesagem final após uma hora (Garcia,1993). A quantidade de matéria seca foi determinada através da eq. (3):

$$
\text { Produção MS }\left(\mathrm{Kg} \mathrm{ha}^{-1}\right)=\frac{\text { Pr od.ForragemVerde.Porcentagem.M.S.daForragem }}{100}
$$

Foram utilizados dados de produção de capim tanzânia (Panicum maximum jacq cv. tanzânia), do experimento citado, com intervalos de cortes pré-estabelecido.

\subsection{A unidade fototérmica}

Com o objetivo de ajustar o efeito da temperatura do ar e do fotoperíodo sobre a resposta da planta, propõe-se o uso da unidade fototérmica para previsão da produtividade de plantas forrageiras em resposta às oscilações estacionais do ambiente. A unidade fototérmica foi definida por Villa Nova et al. (1983) pela eq. (4):

$$
U F=\frac{\left(\frac{n}{2} \overline{G D}\right)^{\frac{N f}{N i}+1}}{\frac{N f}{N i}+1}
$$

em que $U F$ é o número de unidades fototérmicas correspondente ao período de $\mathrm{n}$ dias de desenvolvimento após a desfolha; $\overline{G D}$ os graus-dia médios do período de $\mathrm{n}$ dias; $N f$ o valor do período (horas e décimos), no final do período de crescimento, e $\mathrm{Ni}$ o valor do fotoperíodo, no início do período de crescimento. 
O valor de $\overline{G D}$ é expresso, de acordo com Villa Nova et al. (1972), pelas eq. (5) e (6):

$$
\begin{aligned}
& \overline{G D}=(\bar{T}-15)-C \\
& \overline{G D}=\frac{(\overline{T x}-15)^{2}}{2(\overline{T x}-\overline{T m})}-C
\end{aligned}
$$

em que $\overline{G D}$ é o grau-dia médio do período de $\mathrm{n}$ dias; $\overline{T x}$ a média das temperaturas máximas do ar no período; $\overline{T m}$ a média das temperaturas mínimas do ar no período; $\bar{T}$ a temperatura média do ar no período, calculada pela média de $\overline{T x}$ e $\overline{T m}$ e $C$ a correção de temperatura base superior.

Observa-se que a equação (5) deve ser utilizada quando a temperatura mínima do ar no período for maior que $15{ }^{\circ} \mathrm{C}$, que corresponde à temperatura base inferior. Quando $\overline{T m}$ for menor que $15{ }^{\circ} \mathrm{C}$, a equação (6) deverá ser utilizada.

A correção da temperatura base superior só deverá ser feita quando a temperatura média do ar no período, $\bar{T}$, for maior que $30{ }^{\circ} \mathrm{C}$. A eq. (7) para o cálculo de $C$ é a seguinte:

$$
C=\frac{(\overline{T x}-30)^{2}}{2(\overline{T x}-\overline{T m})}
$$

Os valores de $N(N f$ ou $N i)$, para qualquer dia do ano, podem ser obtidos pelas eq. (8) e (9):

$$
N=0,1333 \arccos (-\operatorname{tg} \delta \cdot \operatorname{tg} \phi)
$$




$$
\delta=23,45 \operatorname{sen}\left[\frac{360}{365}(D J-80)\right]
$$

em que $N$ é o fotoperíodo (horas e décimos); $\varnothing$ a latitude do local (graus e décimos; negativa Sul, positiva Norte); $\delta$ a declinação solar (graus e décimos), e $D J$ o dia juliano (número de ordem a partir de 01 de Janeiro).

Os dados de temperatura máxima e mínima e de precipitação foram coletados de uma mini estação meteorológica, localizada dentro da área do experimento. A cada hora, registraram-se num mini datalogger, os dados de temperatura diária e de precipitação; no final do dia, têm-se 24 valores de temperaturas, observando-se assim, a máxima e a mínima temperatura do dia.

\subsection{Modelando produção a partir de unidades fototérmicas}

A porcentagem do acúmulo de forragem, em função da temperatura do ar e do fotoperíodo, depende de seu estádio de desenvolvimento. O estudo do crescimento de gramíneas forrageiras tem demonstrado que elas apresentam, geralmente, uma curva assintótica de crescimento, que, muitas vezes, apresenta a forma de uma sigmóide, quando submetidas a cortes drásticos. Assim, espera-se que a resposta da planta à temperatura do ar e ao fotoperíodo não seja sempre a mesma durante seu desenvolvimento e, portanto, que a função que correlaciona produção e unidades fototérmicas $(P=f(U F))$ não seja linear, conforme eq. (10) de Villa Nova et al. (1999).

$$
P=\frac{A}{1+e^{B-C . U F}}
$$

em que $P$ é a produção de matéria seca ( $\mathrm{t} \mathrm{ha}^{-1}$ no período de $\mathrm{n}$ dias); $A, B$ e $C$ são parâmetros de ajuste da equação, em função da produção de matéria seca do capim tanzânia, e $U F$ é a unidade fototérmica correspondente ao período de $\mathrm{n}$ dias. 
Com a $U F$ calculada a cada ciclo, pode-se estimar a produção de matéria seca; lança-se esse valor na planilha eletrônica, fazendo todo um estudo que envolve as várias condições que influenciam o custo de produção, como: a) custo local da energia, b) porcentagem de perda de matéria seca, c) necessidade de água da pastagem, d) custo da terra, e) custo da água, f) ganho de peso, g) temperaturas máximas e mínimas da região, h) distância da rede de energia, i) cerca elétrica, j) implantação do pasto, k) custo da implantação do sistema de irrigação, 1) preço da arroba, m) custos com insumos, n) manutenção do sistema de irrigação, o) custos com vacinas, suplementação mineral, p) calagem, q) área de apoio.

Com todas as informações e dados coletados, pode-se simular diferentes análises econômicas, de acordo com as particularidades de cada produtor.

\section{5 Índice de área foliar}

O índice de área foliar (IAF) foi medido antes de cada corte, utilizando-se medidor de área foliar LI-COR, modelo LAI 2000. Dentro de cada subparcela, foram coletados 10 pontos na diagonal, a fim de minimizar-se o erro amostral. O LAI-2000 utiliza um sensor de luz que mede a radiação difusa, simultaneamente, em 5 bandas angulares distintas $\left(0-13^{\circ}, 16-28^{\circ}, 32-43^{\circ}, 47-58^{\circ}\right.$ e $\left.61-74^{\circ}\right)$. O sensor é constituído de cinco fotodiodos, cujas superfícies ativas estão arranjadas em anéis concêntricos. A imagem do dossel, em forma quase hemisférica, é projetada dentro desses anéis, permitindo, para cada intervalo angular, a medição da radiação na banda e no ângulo zenital conhecido. Um filtro óptico restringe a transmissão radiativa para comprimentos de onda menores que $490 \mathrm{~mm}$ (LICOR, 1992). Na prática, a fração de abertura em 5 ângulos zenitais pode ser obtida realizando-se uma medição de referência externa ao dossel e uma ou mais leituras abaixo do dossel. A razão entre as leituras obtidas abaixo do dossel e as obtidas fora do dossel é usada para criar-se uma estimativa da fração de abertura nos cinco ângulos. Analiticamente, tem-se a eq. (11) (Welles, 1990): 


$$
L=2 \int_{0}^{\pi / 2}-\ln (T(\theta)) \cos \theta \operatorname{sen} \theta d \theta
$$

em que $T(\theta)$ é a probabilidade da não interceptação da radiação difusa para um dado ângulo de visada $(\theta)$. O LAI-2000 resolve a eq. (11) numericamente, desde que se tenham fixado cinco ângulos zenitais, processos que permite que tome forma a eq. (12):

$$
L=2 \sum_{i=1}^{5} \frac{-\ln \left(T_{i}\right)}{S_{i}} W_{i}
$$

em que $L$ é o índice de área foliar, $T_{i}$ são as 5 frações de abertura, $W_{i}$ equivale a $\operatorname{sen} \theta d \theta$ para cada um dos cinco ângulos de visada do LAI-2000 e $S_{i}=1 / \cos \theta$.

O equipamento LAI-2000 exige que se faça uma leitura de referência externa ao dossel, já que existe a possibilidade de que as condições de iluminação do céu mudem entre a leitura de referência e a leitura abaixo do dossel, se o intervalo de tempo entre as medidas for considerável.

\subsection{Avaliação econômica}

As áreas de abrangência deste estudo foram as regiões de Piracicaba - SP (Latitude $22^{\circ} 33^{\prime} \mathrm{S}$, Longitude $47^{\circ} 43^{\prime} \mathrm{W}$ ), a uma altitude de $490 \mathrm{~m}$, e Aragarças - GO (Latitude $15^{\circ} 54^{\prime} \mathrm{S}$, Longitude $52^{\circ} 13^{\prime} \mathrm{W}$ ), a $345 \mathrm{~m}$ de altitude, com as variações climáticas normais de temperatura e de precipitação, conforme software Balanço Hídrico - BRASIL (Sentelhas \& Rolim, 1999).

Considerou-se uma área de 102,95 ha hipotética, nas respectivas regiões, com pastagem instalada de capim tanzânia sob pastejo rotacionado. As produtividades do pasto irrigado foram estimadas através dos dados de temperatura média mensal e de fotoperíodo, de acordo com metodologia proposta por Villa Nova et al. (1999). A capacidade de armazenamento de água no solo foi considerada de $100 \mathrm{~mm}$ para as regiões. 
Adotou-se a irrigação por aspersão, sistema pivô central. Submeteu-se a uma empresa de irrigação (IRRIGAPLAN S.A.), para orçamento, uma situação hipotética de projeto, o desejando representar as situações possíveis de irrigação nas respectivas regiões. Os custos totais de produção do sistema irrigado foram determinados pela soma entre o custo total de produção (exceto irrigação) e o custo total do sistema de irrigação (fixo + variável).

A adubação foi de 300, 600 e $900 \mathrm{~kg} \mathrm{~N} \mathrm{ha}^{-1}$ ano $^{-1}$ para os sistemas de pastejo de sequeiro e irrigado, respectivamente. O consumo médio diário por animal foi de $2,1 \%$ do peso vivo; as perdas no pastejo ficaram em $40 \%$. O custo da água foi considerado de $\mathrm{R} \$ 0,01 \mathrm{~m}^{3}$ em função do atual estádio de gestão dos recursos hídricos no Brasil. O valor da arroba (@) no mercado foi considerado de 35, 40 e 45 (R\$) para as regiões de Piracicaba - SP e Aragarças - GO, o dólar comercial, cotado em R \$2,38.

O custo da tarifa elétrica foi calculado pela média ponderada, para os consumidores do Subgrupo A4, no qual se incluem os rurais; concederam-se descontos especiais para os irrigantes, já que solicitaram tal benefício, conforme a Portaria $n^{\circ} 105$ de 3 de abril 1992 do DNAEE. Porém, tais descontos incidem somente sobre o consumo de energia elétrica entre as 23 e as 5 h, sendo necessário exclusividade para irrigação, ou seja, a rede elétrica para o sistema de irrigação deve ser independente das demais da propriedade, além do que os equipamentos de medição e de controle da energia fornecida ficam a cargo do consumidor. Os descontos variam conforme a região do país, sendo igual a 90 \% para o Nordeste e regiões geoeconômicas denominadas Vale do Jequitinhonha e Polígono da Seca, no Estado de Minas Gerais; 80 \% para o Norte e Centro-Oeste e demais regiões do Estado de Minas Gerais e 70 \% para as demais regiões do país. Para o cálculo da tarifa ponderada de consumo (tarifa verde período seco fora de ponta + desconto citado acima de acordo com a região), utilizou a eq. (13):

$$
T p=\frac{(h s \cdot T v)+[(h c \cdot T v) \cdot(1-D t)]}{h t}
$$


em que $T p$ é a tarifa ponderada de consumo da energia elétrica $\left(\mathrm{R} \$ \mathrm{kWh}^{-1}\right)$; $h$ é o tempo de funcionamento do sistema de irrigação sem desconto noturno (horas); $T v$ é o preço da tarifa verde período seco fora de ponta $\left(\mathrm{R} \$ \mathrm{kWh}^{-1}\right) ; h c$ é a horas de funcionamento do sistema de irrigação com desconto noturno (horas); $D t$ é o desconto concedido conforme a Portaria $n^{0} 105$ de 3 de abril 1992 do DNAEE; $h t$ é a horas de trabalho do pivô por dia (21h). Calculou-se o valor da tarifa ponderada por região e, depois, fez-se uma média nacional do preço da tarifa elétrica fora de pico: no período seco, foi de $\mathrm{R} \$ 0,07 \mathrm{kWh}$, já a tarifa de demanda fora de ponta do período seco foi de $\mathrm{R} \$ 5,85 \mathrm{~kW}$.

Os retornos econômicos a otimizar foram determinados através da metodologia proposta por Franke et al., (1998) e calculados pela seguinte eq. (14):

$$
L=(R B-C F-C A E-C E-C M O-C C R M-C c)
$$

em que $L$ é a receita líquida obtida pelo sistema.

$$
R B=Y \cdot P
$$

em que $R B$ é a receita bruta $\left(\mathrm{R} \$ \mathrm{ha}^{-1}\right) ; Y$ é a produção da pastagem $\left(\mathrm{t} \mathrm{MS} \mathrm{ha}{ }^{-1} \mathrm{ano}^{-1}\right) ; P$ é o preço da arroba do boi gordo (R\$) e $C F$ é o custo de formação da pastagem. Incluemse aí todos os custos de preparo, semeadura, tratos culturais, defensivos, seguro agrícola, custo financeiro, assistência técnica e transporte em todas as épocas de semeadura. O custo de amortização do capital do equipamento (CAE) foi definido através da eq. (16):

$$
C A E=\frac{C \cdot J \cdot H \cdot h t}{L m \cdot A \cdot V u}
$$

em que $C A E$ é o custo de amortização anual do equipamento $\left(\mathrm{R} \$ \mathrm{ha}^{-1}\right), J$ é o fator de recuperação do capital, definido pela eq. (17): 


$$
J=\frac{j \cdot(1+j)^{N e}}{\left[(1+j)^{N e}-1\right]}
$$

em que $j$ é a taxa anual de juros (adotou-se 12\% ao ano); $N e$ é o número de anos do empréstimo; $C$ é o valor de aquisição do equipamento $(\mathrm{R} \$) ; H$ é a lâmina de irrigação suplementar necessária no ciclo $(\mathrm{mm}), V u$ é a vida útil do equipamento; $A$ é a área irrigada pelo equipamento (102,95 ha); Lm é a intensidade de precipitação do equipamento $\left(\mathrm{mm} \mathrm{h}^{-1}\right)$, sendo igual a $10 \mathrm{~mm} \mathrm{dia}^{-1}$; $h t$ é a horas de trabalho do pivô por dia $(21 \mathrm{~h})$. $\mathrm{O}$ custo da energia elétrica $(C E)$ foi definido pela eq. (18):

$$
C E=(E b \cdot T p)+(D p \cdot T d)+[D p \cdot T d \cdot(12-x) \cdot y]
$$

em que $C E$ é o custo da energia elétrica $\left(\mathrm{R} \$ \mathrm{ha}^{-1}\right), E b$ é a energia requerida pela unidade de bombeamento ( $\left.\mathrm{kWh} \mathrm{ha}^{-1}\right)$, calculado conforme a eq. (19):

$$
E b=\frac{10 \cdot H \cdot H m \cdot g \cdot y_{a}}{3,6 \cdot 10^{6} \cdot \eta}
$$

em que $H m$ é a altura manométrica total $(\mathrm{m}) ; y_{a}$ é a densidade da água $\left(\mathrm{kg} \mathrm{m}^{-3}\right) ; g$ é a aceleração da gravidade $\left(\mathrm{m} \mathrm{s}^{-2}\right)$; $\eta$ é a eficiência global do conjunto motobomba igual a 0,616, segundo Batty \& Keller (1980); Tp é a tarifa ponderada de consumo da energia elétrica $\left(\mathrm{R} \$ \mathrm{kWh}^{-1}\right) ; T d$ é a tarifa de demanda de potência $\left(\mathrm{R} \$ \mathrm{~kW}^{-1}\right) ; x$ é o número de meses em que o sistema será operado pelo menos uma vez (fato suficiente para o medidos registrar $100 \%$ da potência instalada, valor que é utilizado pela concessionária de energia como demanda faturável do mês); $y$ é o coeficiente aplicado à demanda faturável; $D p$ é a demanda de potência $\left(\mathrm{kW} \mathrm{ha}^{-1}\right)$, obtida pela eq. (20):

$$
D p=\frac{H m \cdot Q \cdot g \cdot y_{a}}{1000 \cdot A \cdot \eta}
$$


em que $Q$ é a vazão do sistema $\left(\mathrm{m}^{3} \mathrm{~s}^{-1}\right)$. O custo de mão-de-obra $(C M O)$ foi calculado pela eq. (21):

$$
C M O=\frac{1,9627 \cdot S \cdot N H \cdot N h}{A}
$$

em que $C M O$ é o custo da mão de obra $\left(\mathrm{R} \$ \mathrm{ha}^{-1}\right) ; N H$ é o número de homens necessários para operar o sistema; $S$ é o salário médio do trabalhador rural especializado mais 96,27 $\%$ de encargos; Nh é o número de horas do ciclo da cultura em que o equipamento trabalha. $\mathrm{O}$ custo de manutenção $(C C R M)$ foi calculado pela eq. (22):

$$
C C R M=C .0,03
$$

em que $C C R M$ é o custo de manutenção, reparo e conservação ( $\left.\mathrm{R} \$ \mathrm{ha}^{-1}\right)$. Neste estudo, adotou-se $3 \%$ ao ano, custo anual do equipamento. E, finalmente, o custo de comercialização $(C c)$ foi calculado pela eq. (23):

$$
C c=(Y . c t)+(R B . f r)
$$

em que $C c$ é o Custo da comercialização $\left(\mathrm{R} \$ \mathrm{t}^{-1}\right)$; $c t$ é o custo do transporte da produção

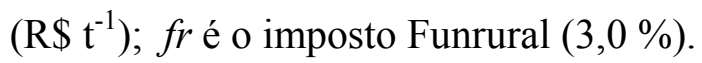

A taxa interna de retorno (TIR) de um projeto é aquela que torna o valor dos lucros futuros equivalentes aos dos gastos realizados com o projeto, ou a taxa de remuneração do capital investido. No caso da avaliação de um projeto por esse critério, sua aceitação, no sentido de ser economicamente desejável, ocorrerá se a sua TIR for superior a uma dada taxa de juros, sobre o investimento, podendo ser comparada diretamente com o custo do capital, ou com as alternativas de aplicação dos recursos no mercado financeiro (Frizzone et al., 2000). 


\section{RESULTADOS E DISCUSSÃO}

\subsection{Condução da irrigação}

Para repor a água perdida nas parcelas experimentais, utilizou-se a irrigação por gotejamento, com emissores autocompensantes, distanciados em $50 \mathrm{~cm}$ na linha irrigada, e $70 \mathrm{~cm}$ entre linhas, distribuídos sobre a superfície do solo. Cada gotejador apresenta uma vazão de $2,0 \mathrm{~L} \mathrm{~h}^{-1}$, sendo as linhas posicionadas dentro das subparcelas.

Na Figura 3, estão representadas as leituras tensiométricas durante os nove períodos de coletas (Janeiro/2001 a Dezembro/2001).

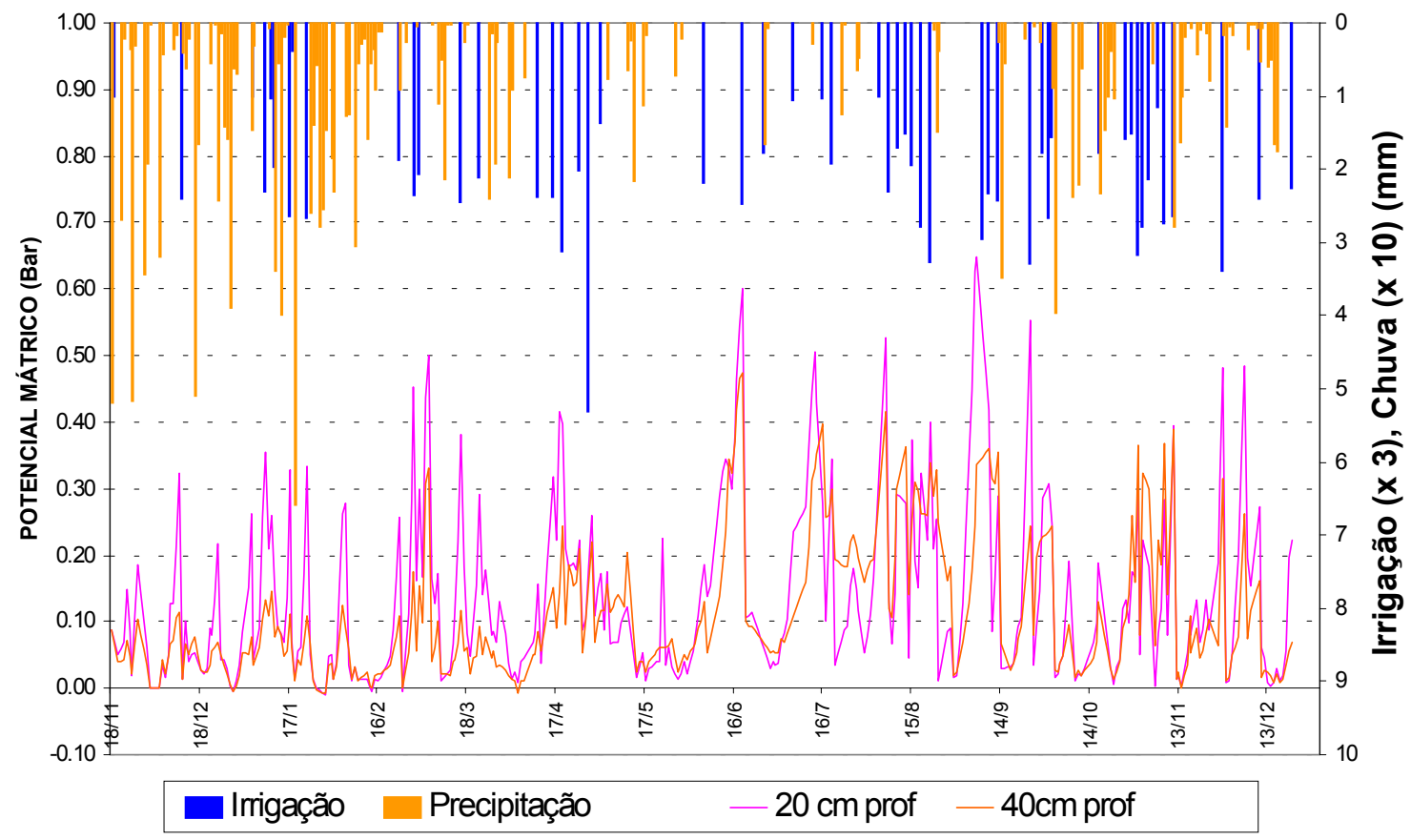

Figura 3 - Variações das leituras tensiométricas no experimento na Fazenda Areão, nos nove cortes efetuados. 
Pode-se observar a eficácia da tensiometria na determinação do potencial matricial da água no solo, durante períodos de chuvas ou irrigações efetuadas.

\subsection{Produção de matéria seca (MS)}

Os dados de produção do capim tanzânia (Panicum maximum jacq cv. tanzânia), após os nove cortes realizados no ano agrícola de janeiro a dezembro de 2001, apresentaram uma variação estacional, compreendendo dois períodos distintos: período de inverno (nos meses de maio, junho, julho, agosto e setembro) e período de verão (nos meses restantes do ano). Verificou-se que houve diferença na interação entre a gramínea e o nível de nitrogênio $(\mathrm{N})$, enquanto as diferentes lâminas de irrigação não apresentaram diferenças significativas de produção (ANOVA), pois o ano de condução do experimento teve elevado índice de precipitação. As produções foram calculadas, levando-se em consideração as diferentes doses de nitrogênio em $\mathrm{kg} \mathrm{MS} \mathrm{ha-1}$, com média de 15 pontos, como mostra a Tabela 1.

A produção de MS aumentou com a elevação dos níveis de $\mathrm{N}$ no capim tanzânia, adubado com $2079 \mathrm{~kg} \mathrm{~N} \mathrm{ha}{ }^{-1}$ ano $^{-1}$, aumentou 16867,86 kg MS ha ${ }^{-1}$, comparado a dose $0 \mathrm{~kg} \mathrm{~N} \mathrm{ha}^{-1} \mathrm{ano}^{-1}$. Este acréscimo, provavelmente, foi devido ao maior perfilhamento proporcionado pela aplicação de N. Este acréscimo também foi verificado por Pereira et al. (1966).

As produções elevadas de MS obtidas, provavelmente, são devidas ao efeito da adubação nitrogenada, mas não podemos desconsiderar a importância da irrigação; no experimento avaliado, as lâminas de irrigação não apresentaram diferenças significativas, pois tivemos um ano atípico, com uma boa distribuição das precipitações. Temos também que levar em consideração a drenagem do solo e sua variabilidade espacial. 
Tabela 1. Médias de produção de matéria seca por pastejo ( $\mathrm{kg} \mathrm{MS} \mathrm{ha}{ }^{-1}$ ) em capim tanzânia, em função dos níveis de adubação nitrogenada, em diferentes períodos de corte.

\begin{tabular}{cccccc}
\hline \multicolumn{5}{c}{ Dose N $\left(\mathrm{kg} \mathrm{ha}^{-1} \mathrm{ano}^{-1}\right)$} \\
\hline Corte & 0 & 100 & 275 & 756 & 2079 \\
\hline $1^{\circ}$ & 1302,8 & 1747,1 & 2199,3 & 3301,8 & 4570,8 \\
$2^{\mathrm{o}}$ & 1199,2 & 1403,8 & 1800,8 & 2165,1 & 3045,8 \\
$3^{\mathrm{o}}$ & 1080,3 & 1382,6 & 1588,8 & 2489,6 & 2683,4 \\
$4^{\mathrm{o}}$ & 472,7 & 481,0 & 594,8 & 823,6 & 903,9 \\
$5^{\mathrm{o}}$ & 292,3 & 342,6 & 503,6 & 736,8 & 827,4 \\
$6^{\circ}$ & 327,0 & 465,9 & 810,4 & 1242,8 & 1503,9 \\
$7^{\circ}$ & 366,4 & 514,8 & 997,7 & 1945,3 & 2153,1 \\
$8^{\circ}$ & 863,7 & 1047,1 & 1820,6 & 3082,6 & 3695,3 \\
$9^{\circ}$ & 915,4 & 1100,4 & 2081,3 & 4010,9 & 4304,1 \\
Total & 6819,8 & 8485,3 & 12397,2 & 19798,5 & 23687,7 \\
\hline
\end{tabular}

Na Figura 4, mostra-se o efeito da estacionalidade de produção do capim tanzânia, em função das diferentes doses de adubação nitrogenada ao longo do ano.

A produção total de MS, nos cinco níveis de adubação 0, 100, 275, 756 e 2079 $\mathrm{kg} \mathrm{N} \mathrm{ha}^{-1}$ ano $^{-1}$, foi de 6819,$84 ; 8485,25 ; 12397,16 ; 19798,45$ e $23687,69 \mathrm{~kg} \mathrm{MS} \mathrm{ha}{ }^{-1}$ $\mathrm{ano}^{-1}$. A produção média por período de MS, nos cinco níveis de adubação $0,100,275$, 756 e $2079 \mathrm{~kg} \mathrm{~N} \mathrm{ha}^{-1}$ ano $^{-1}$, foi, no inverno, de 543,08; 668,01; 874,39; 1323,20 e $1479,63 \mathrm{~kg} \mathrm{MS} \mathrm{ha}^{-1}$, respectivamente, e, no verão, de 929,50; 1162,64; 1779,92; 2901,13 e $3553,83 \mathrm{~kg} \mathrm{MS} \mathrm{ha}^{-1}$. 


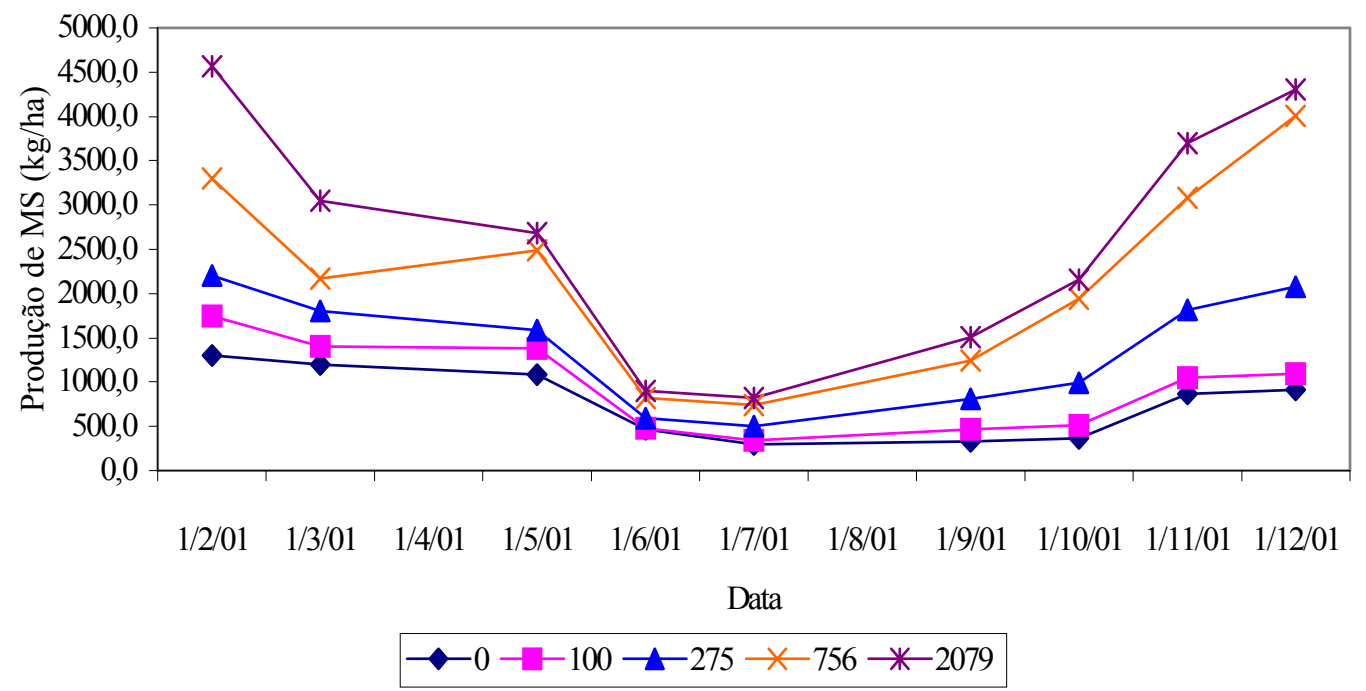

Figura 4 - Produção de matéria seca por coleta $\left(\mathrm{kg} \mathrm{MS} \mathrm{ha}^{-1}\right)$ do capim tanzânia, durante o período experimental de 02/01/01 à 21/12/01.

A produção de matéria seca do capim tanzânia, avaliada na época de corte no período de 02/01/2001 a 21/12/2001, apresenta uma estacionalidade de produção devido aos fatores de crescimento (radiação solar e temperatura), chegando à máxima produção de 4570,80 $\mathrm{kg} \mathrm{MS} \mathrm{ha}^{-1}$, no mês de fevereiro, após um período de 36 dias de descanso, com adubação $2079 \mathrm{~kg} \mathrm{~N} \mathrm{ha}^{-1}$ ano $^{-1}$ e à mínima produção de 292,30 $\mathrm{kg} \mathrm{MS} \mathrm{ha}^{-1}$, no mês de julho, após um período de 36 dias de descanso.

\subsection{Cálculo da unidade fototérmica}

As temperaturas do ar foram calculadas para cada período, conforme a metodologia proposta por Villa Nova et al. (1999); as estações do ano foram bem definidas, constituindo um ano atípico, como o inverno com elevado índice pluviométrico. A unidade fototérmica calculada para cada período correspondente encontra-se na Tabela 2. 
Tabela 2. Dados meteorológicos, fotoperíodo (N), unidades fototérmicas (UF), nas épocas correspondentes a cada corte, ano agrícola de 2001, em Piracicaba$\mathrm{SP},\left(\mathrm{Lat}=22,71^{\circ} \mathrm{S}\right)$.

\begin{tabular}{ccccccccc}
\hline Período & $\begin{array}{c}\mathrm{n} \\
(\text { dias })\end{array}$ & $\begin{array}{c}\overline{T x} \\
\left({ }^{\circ} \mathrm{C}\right)\end{array}$ & $\begin{array}{c}\overline{T m} \\
\left({ }^{\circ} \mathrm{C}\right)\end{array}$ & $\begin{array}{c}\bar{T} \\
\left({ }^{\circ} \mathrm{C}\right)\end{array}$ & $\begin{array}{c}n \overline{G D} \\
2\end{array}$ & $\begin{array}{c}\mathrm{Ni} \\
\text { (horas) }\end{array}$ & $\begin{array}{c}\mathrm{Nf} \\
\text { (horas) }\end{array}$ & UF \\
\hline $02 / 01-06 / 02$ & 36 & 31,5 & 20,0 & 25,8 & 193,9 & 13,4 & 12,9 & 15993,00 \\
$14 / 02-21 / 03$ & 36 & 30,7 & 19,8 & 25,3 & 185,1 & 12,8 & 12,0 & 12863,07 \\
$30 / 03-04 / 05$ & 36 & 30,2 & 17,2 & 23,7 & 156,7 & 11,8 & 11,1 & 9218,11 \\
$11 / 05-15 / 06$ & 36 & 25,2 & 13,4 & 19,3 & 79,0 & 11,0 & 10,6 & 2747,87 \\
$20 / 06-25 / 07$ & 36 & 25,2 & 10,5 & 17,9 & 63,8 & 10,6 & 10,9 & 2232,79 \\
$27 / 07-31 / 08$ & 36 & 26,5 & 12,3 & 19,4 & 84,1 & 10,9 & 10,6 & 4523,72 \\
$03 / 09-08 / 10$ & 36 & 27,3 & 15,0 & 21,1 & 110,7 & 11,6 & 12,4 & 8196,14 \\
$10 / 10-14 / 11$ & 36 & 29,4 & 16,9 & 23,1 & 146,7 & 12,4 & 13,1 & 13735,93 \\
$16 / 11-21 / 12$ & 36 & 29,6 & 19,1 & 24,4 & 168,4 & 13,1 & 13,4 & 15489,53 \\
\hline
\end{tabular}

As temperaturas do ar foram calculadas, para cada período do ano, de acordo com a temperatura máxima e a mínima do ar e sua amplitude.

\subsection{Ajuste dos modelos de estimativa de produção de matéria seca}

A partir dos dados de produção do capim tanzânia sob irrigação e diferentes doses de nitrogênio, foi realizada uma nova parametrização dos coeficientes, de acordo com a dose de adubação nitrogenada. Ajustaram-se os modelos para 0, 100, 275, 756 e $2079 \mathrm{~kg} \mathrm{~N} \mathrm{ha}^{-1}$ ano $^{-1}$, doses divididas em nove aplicações, com um ciclo de 36 dias de descanso ao longo do ano, não variando os dias de descanso no período de inverno, para poder-se ajustar os parâmetros dos modelos matemáticos para cada dose de adubação nitrogenada. Para as doses 0, 100, 275, 756 e $2079 \mathrm{~kg} \mathrm{~N} \mathrm{ha}^{-1}$ ano $^{-1}$, o teste dos modelos mostrou boa capacidade em estimar a produção anual de matéria do capim tanzânia. Nas Figuras 5, 6, 7, 8 e 9, são apresentadas as curvas de ajuste obtidas entre os parâmetros: 
produção de matéria seca ( $\mathrm{t} \mathrm{ha}^{-1}$ no período de 36 dias) e unidade fototérmica, correspondentes ao período de 36 dias.

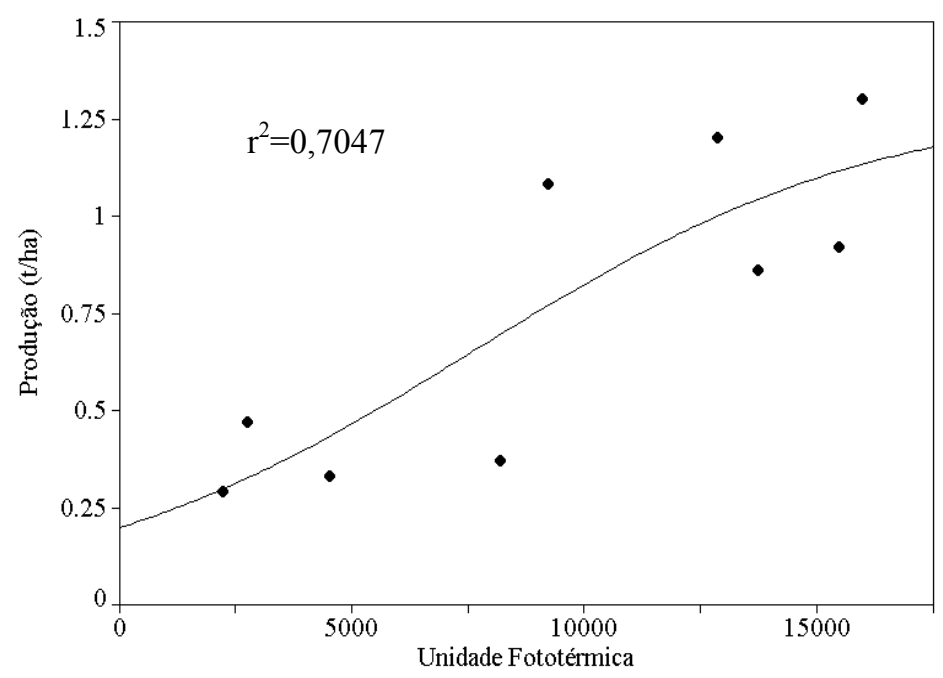

Figura 5 - Ajuste entre os dados observados de produção de matéria seca e as unidades fototérmicas para o capim tanzânia, dose $0 \mathrm{~kg} \mathrm{~N} \mathrm{ha}^{-1} \mathrm{ano}^{-1}$ (período de crescimento de 36 dias).

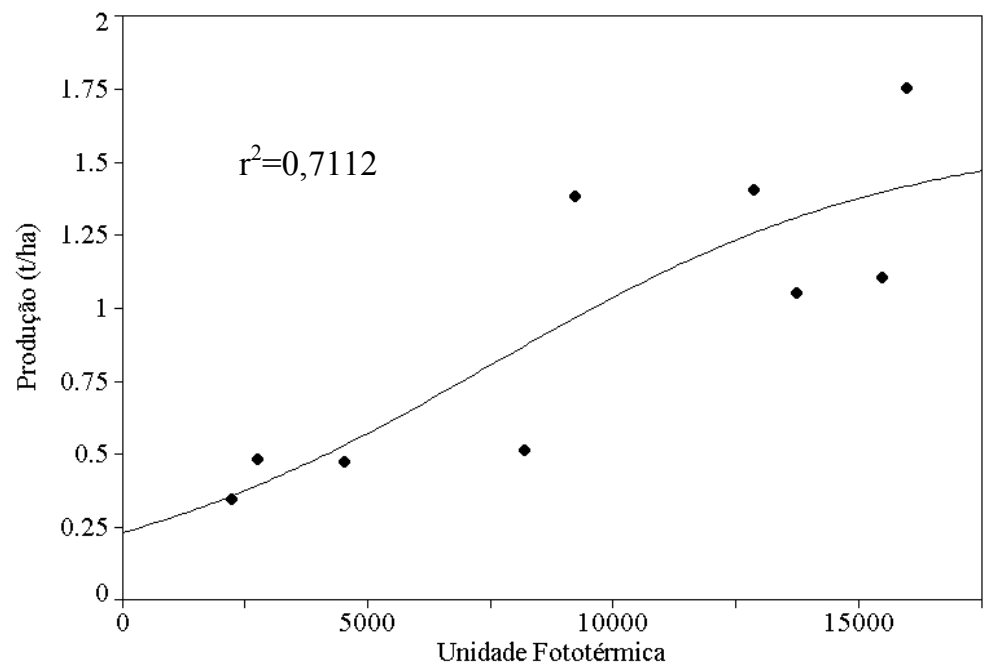

Figura 6 - Ajuste entre os dados observados de produção de matéria seca e as unidades fototérmicas para o capim tanzânia, dose $100 \mathrm{~kg} \mathrm{~N} \mathrm{ha}^{-1} \mathrm{ano}^{-1}$ (período de crescimento de 36 dias). 


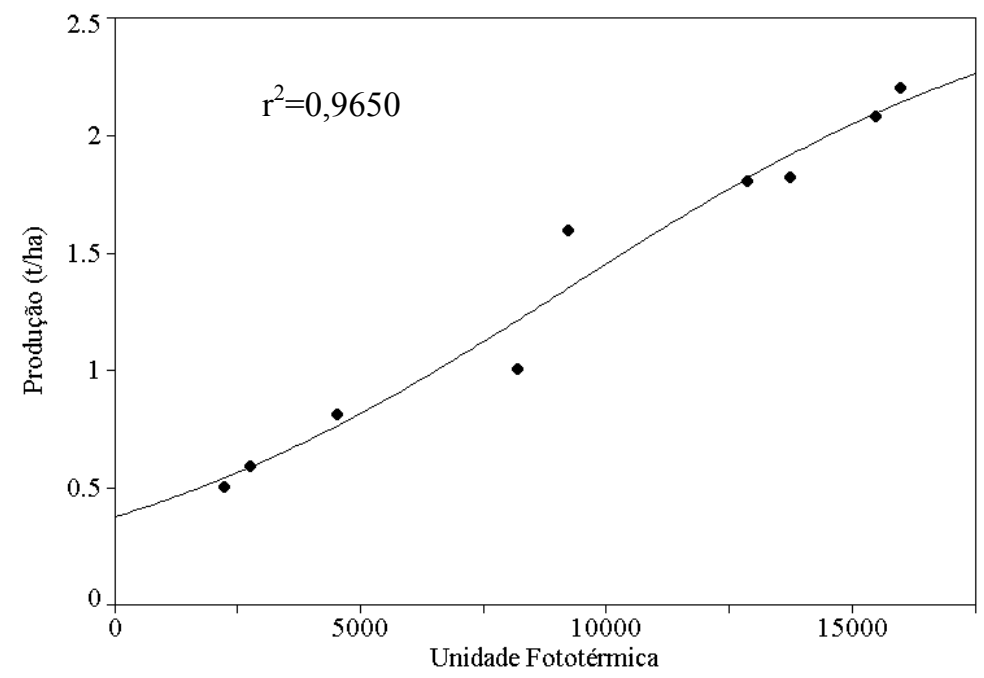

Figura 7 - Ajuste entre os dados observados de produção de matéria seca e as unidades fototérmicas para o capim tanzânia, dose $275 \mathrm{~kg} \mathrm{~N} \mathrm{ha}^{-1} \mathrm{ano}^{-1}$ (período de crescimento de 36 dias).

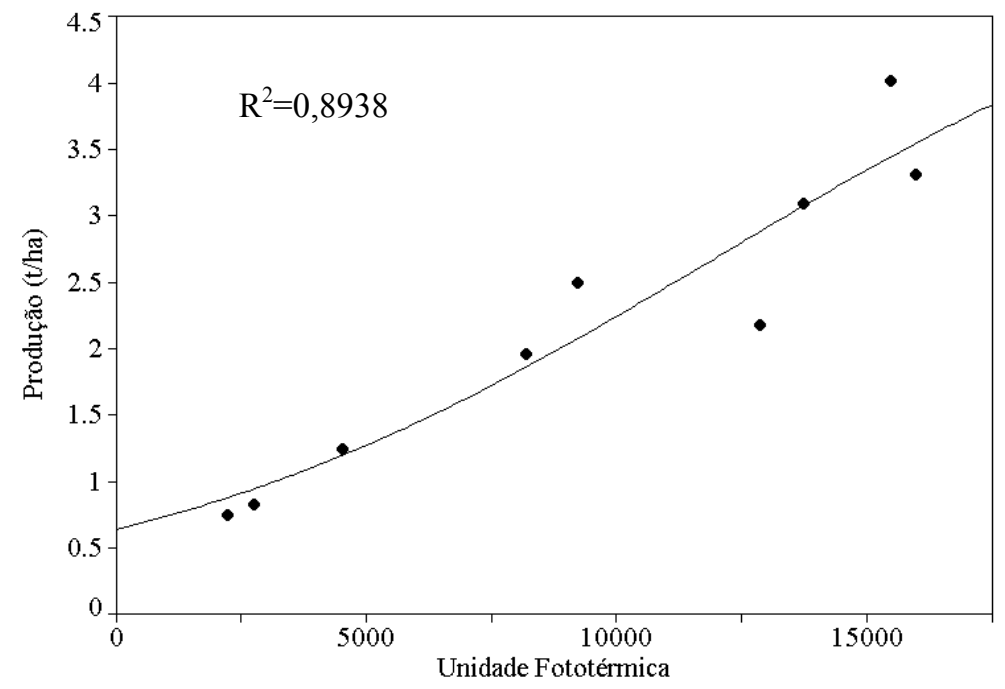

Figura 8 - Ajuste entre os dados observados de produção de matéria seca e as unidades fototérmicas para o capim tanzânia, dose $756 \mathrm{~kg} \mathrm{~N} \mathrm{ha}^{-1} \mathrm{ano}^{-1}$ (período de crescimento de 36 dias). 


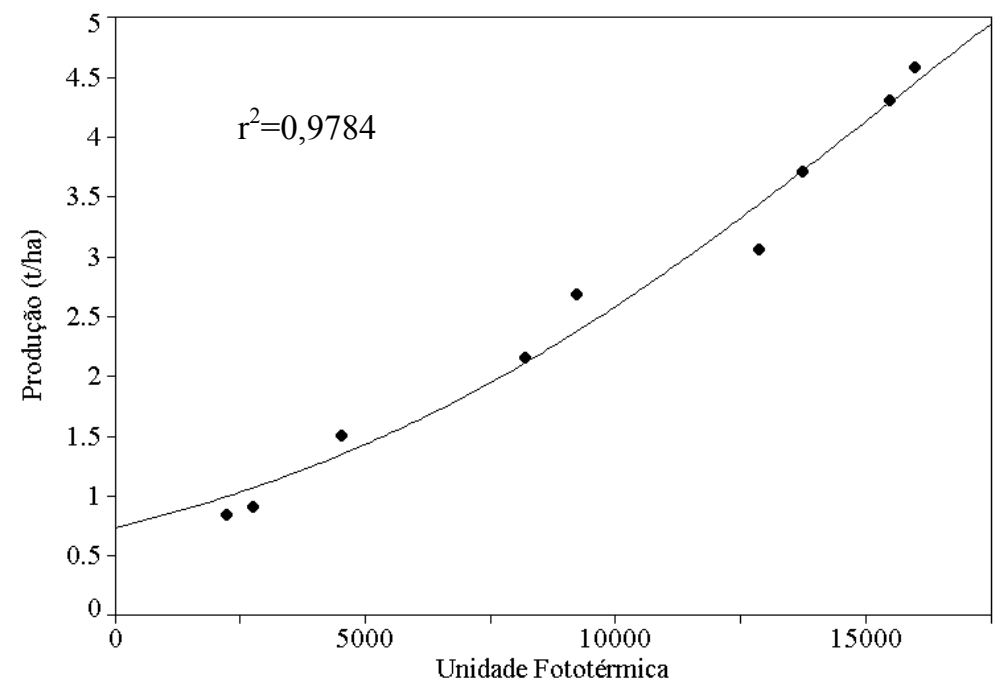

Figura 9 - Ajuste entre os dados observados de produção de matéria seca e as unidades fototérmicas para o capim tanzânia, dose $2079 \mathrm{~kg} \mathrm{~N} \mathrm{ha}^{-1} \mathrm{ano}^{-1}$ (período de crescimento de 36 dias).

Feitas as curvas de ajuste entre os dois parâmetros, para as diferentes doses de adubação nitrogenada, obtiveram-se as funções de Gompertz, parametrizadas ( $P$ é a produção t MS ha ${ }^{-1}$ ) para as doses de 0, 100, 275, 756 e $2079 \mathrm{~kg} \mathrm{~N} \mathrm{ha}^{-1} \mathrm{ano}^{-1}$, nas eq. (24), (25), (26), (27) e (28) respectivamente.

$$
\begin{aligned}
& P=\frac{1,3}{1+e^{1,72-2,269 \times 10^{-4} U F}} \\
& P=\frac{1,6}{1+e^{1,80-2,398 \times 10^{-4} U F}} \\
& P=\frac{2,7}{1+e^{1,83-1,982 \times 10^{-4} U F}} \\
& P=\frac{5,3}{1+e^{2,01-1,683 \times 10^{-4} U F}} \\
& P=\frac{8,6}{1+e^{2,38-1,538 \times 10^{-4} U F}}
\end{aligned}
$$


Os ajustes dos modelos para as doses de 0 e $100 \mathrm{~kg} \mathrm{~N} \mathrm{ha}^{-1} \mathrm{ano}^{-1}$, foram $\mathrm{r}^{2}$ de 0,7047 e 0,7112, respectivamente, pois tais doses de adubação apresentaram produções elevadas de MS até o terceiro corte, devido aos resíduos de adubação de culturas anteriores na área do experimento ou mesmo em decorrência da própria fertilidade natural do solo que, com o passar dos cortes, se foi esgotando. Já no sétimo corte (outubro), as produções foram baixas não seguindo a variação da unidade fototérmica, pois as doses de 0 e $100 \mathrm{~kg} \mathrm{~N} \mathrm{ha}^{-1}$ ano $^{-1}$, não foram suficientes para manter o capim tanzânia em produção. Para as doses de adubações 275, 756 e $2079 \mathrm{~kg} \mathrm{~N} \mathrm{ha}^{-1} \mathrm{ano}^{-1}$, as regressões respectivas foram de $r^{2}=0,9650 ; r^{2}=0,8938$ e $r^{2}=0,9784$. Os ajustes dos parâmetros entre a produção de MS e a unidade fototérmica mostraram-se com boa capacidade de estimar a produção anual de MS do capim tanzânia.

Para idealizar um modelo matemático que com base na unidade fototérmica e na adubação nitrogenada, estimasse a produção de MS do capim tanzânia, foi ajustada uma função tridimensional, como mostra a Figura 10, utilizada nas análises de viabilidade econômica efetuadas.

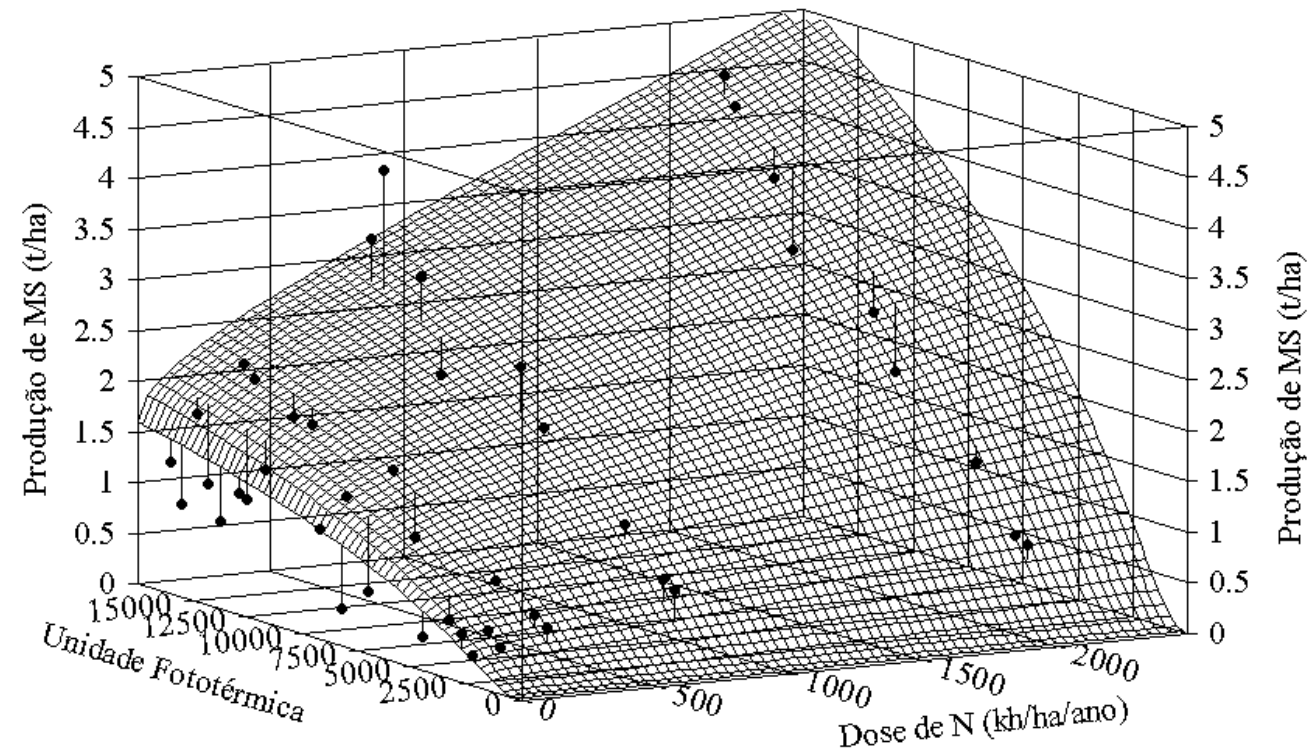

Figura 10 - Valores observados e ajustados de produção de matéria seca em função das unidades fototérmicas disponíveis e doses de 0, 100, 275, 756 e $2079 \mathrm{~kg} \mathrm{~N}$ $\mathrm{ha}^{-1} \mathrm{ano}^{-1}$ (período de crescimento de 36 dias). 
O modelo de produtividade ajustado, eq. (29), apresentou um $\mathrm{r}^{2}$ de 0,8731, sendo de boa confiança para estimativa da produção de matéria seca do capim tanzânia, em função da adubação nitrogenada e da disponibilidade de unidade fototérmica local, sendo assim, pode-se extrapolar para várias regiões do país, a produção de MS do capim tanzânia.

$$
\ln z=1,5238+0,0230 \cdot N^{0,5}+\frac{(-138,7039)}{U F^{0,5}}
$$

em que $z$ é a produção de MS em ( $\left.\mathrm{t} \mathrm{ha}^{-1}\right) ; N$ é a adubação em $\mathrm{kg} \mathrm{N} \mathrm{ha}^{-1}$ ano $^{-1}$ e $U F$ é a unidade fototérmica corresponde ao período de $\mathrm{n}$ dias.

\section{5 Índice de área foliar}

Os dados de índice de área foliar foram coletados somente a partir do segundo corte, devido a indisponibilidade do equipamento no início do experimento. Na Tabela 3, são apresentados os efeitos das doses de nitrogênio e sua interação no índice de área foliar (IAF). Notou-se que o IAF diferenciou em função das doses de nitrogênio e acompanhou a variação de produção de MS, ao longo do ano. O IAF das gramíneas aumentou com a elevação nos níveis de nitrogênio. A média do IAF no período do inverno (maio, junho, julho, agosto e setembro) para o capim tanzânia nas doses de 0 , 100, 275, 756 e $2079 \mathrm{~kg} \mathrm{~N} \mathrm{ha-1}$ ano $^{-1}$, variou de 2,55;2,49; 2,76; 3,50 e 3,18 respectivamente; já no período do verão variou de 3,$70 ; 3,81 ; 4,62 ; 5,82$ e 6,14, respectivamente. Provavelmente, isso se deva ao favorecimento do nitrogênio na produção de folhas novas e ao melhor perfilhamento, também observados por Nabinger, (1997). 
Tabela 3. Médias do índice de área foliar em capim tanzânia, em função dos níveis de adubação nitrogenada, nos diferentes períodos de corte.

\begin{tabular}{cccccc}
\hline \multicolumn{5}{c}{ Dose N $\left(\mathrm{kg} \mathrm{ha}^{-1} \mathrm{ano}^{-1}\right)$} \\
\hline Corte & 0 & 100 & 275 & 756 & 2079 \\
\hline $1^{\circ}$ & & & & \\
$2^{\circ}$ & 4,67 & 4,08 & 4,55 & 4,84 & 5,07 \\
$3^{\circ}$ & 3,94 & 3,76 & 3,67 & 4,16 & 3,50 \\
$4^{\circ}$ & 2,25 & 2,40 & 2,54 & 3,41 & 3,09 \\
$5^{\circ}$ & 1,29 & 1,36 & 1,57 & 1,81 & 1,79 \\
$6^{\circ}$ & 2,73 & 2,44 & 3,27 & 4,61 & 4,33 \\
$7^{\circ}$ & 2,81 & 3,16 & 3,95 & 5,56 & 5,81 \\
$8^{\circ}$ & 3,25 & 3,88 & 5,10 & 6,89 & 7,36 \\
$9^{\circ}$ & 4,05 & 4,13 & 4,87 & 6,01 & 6,33 \\
\hline
\end{tabular}

\subsection{Avaliação econômica}

Para a avaliação da viabilidade econômica da irrigação de pastagem, foi desenvolvida uma planilha eletrônica, de simulação econômica, estimando a produção de matéria seca do capim tanzânia em função das seguintes variáveis: condições climatológicas da região, necessidade de irrigação e níveis de adubação nitrogenada.

Foram feitos levantamentos detalhados dos custos fixos e dos variáveis para a implantação do sistema de irrigação, tipo pivô central, em pastejo rotacionado para a engorda de bovinos.

A seguir, serão discriminados os itens que compõem os custos deste tipo de investimento, tentando adequá-los à realidade da pecuária nacional. 


\subsubsection{Custos fixos}

Fez-se um levantamento do que é considerado custo fixo, dentro do sistema de pastagem irrigada: custo do sistema de irrigação, custo de formação de pastagem, custo de implantação do sistema rotacionado (cerca elétrica, bebedouro, cocho). Os custos fixos não variam com a quantidade produzida, sendo calculados em função da taxa de juros, impostos, seguros e depreciação, de acordo com a metodologia proposta por Franke et al. (1998) em todas as análises de viabilidade econômica.

\subsubsection{Custos do sistema de irrigação}

Adotou-se a irrigação por aspersão, sistema pivô central. Submeteu-se à IRRIGAPLAN S/A, situada na cidade de Leme - SP, para orçamento, uma situação hipotética de projeto, com as características descritas, conforme a Tabela 4.

Tabela 4. Características hipotéticas para o projeto do sistema de irrigação tipo pivô central.

\begin{tabular}{lc}
\hline Descrição & \\
\hline Área irrigada & 102,95 ha \\
Desnível geométrico - centro pivô a moto-bomba & $30 \mathrm{~m}$ \\
Lâmina bruta diária (21 horas de funcionamento/dia) & $9 \mathrm{~mm}$ \\
Fonte de acionamento do motor & elétrico \\
\hline
\end{tabular}

O sistema de irrigação, conforme o orçamento proposto, possui $572,46 \mathrm{~m}$ de raio, 11 torres, 250 aspersores, tempo para completar uma volta com relê a $100 \%$ de 13,25 horas, vazão da moto-bomba de $441,23 \mathrm{~m}^{3} \mathrm{~h}^{-1}$, altura manométrica total de 95,42 mca e motor elétrico de $250 \mathrm{cv}$.

Os valores relativos aos componentes do sistema de irrigação são apresentados na Tabela 5, observando-se que o custo total do sistema de irrigação foi 
de $\mathrm{R} \$ 269.111,50$, podendo variar conforme o fabricante e as características locais de cada propriedade.

Tabela 5. Levantamento dos custos de aquisição de um sistema de irrigação, tipo pivô central.

\begin{tabular}{lccc}
\hline Descrição & Quantidade & V. Unitário & V. total \\
\hline Valor do sistema de irrigação & 1 & $160.526,50$ & $160.526,50$ \\
Valor do sistema de bombeamento & 1 & $87.325,00$ & $87.325,00$ \\
Abertura de valetas $(\mathrm{R} \$ / 1000 \mathrm{~m})$ & 1 & $3.000,00$ & $3.000,00$ \\
Construção da casa de bombeamento & 1 & $4.260,00$ & $4.260,00$ \\
Construção da base do pivô & 1 & $1.500,00$ & $1.500,00$ \\
Rede elétrica $(\mathrm{R} \$ \mathrm{~km})$ & 1 & $12.500,00$ & $12.500,00$ \\
Total & & & $269.111,50$ \\
\hline
\end{tabular}

\subsubsection{Custo de formação da pastagem e cerca elétrica}

Para a formação da pastagem, foram levantados os custos com operações mecanizadas, transportes, operações manuais, insumos, vida útil da pastagem. Para efeito da depreciação do valor, foi considerado um período de 10 anos de vida útil da pastagem. Para a correção das características químicas hipotéticas de um solo de média fertilidade, os custo de formação são apresentados na Tabela 6. 
Tabela 6. Custo de formação de pastagem, considerando-se uma área hipotética de implantação do sistema de pastagem irrigado e sequeiro.

\begin{tabular}{lcccc}
\hline Descrição & Qde. & Rendimento & Valor Unitário (R\$) & Valor (R\$/ha) \\
\hline Roçada & 1 & 1,25 & 24,05 & 30,06 \\
Conservação do solo & 1 & 2,47 & 29,68 & 73,30 \\
Calagem & 1 & 0,60 & 26,23 & 15,74 \\
Aração & 1 & 2,47 & 29,68 & 73,30 \\
Grade niveladora & 1 & 0,46 & 30,88 & 42,61 \\
Semeadura à lanço & 1 & 0,40 & 32,00 & 12,80 \\
Adubação de cobertura & 1 & 0,91 & 23,65 & 21,52 \\
Adubação de cobertura & 1 & 0,40 & 26,23 & 10,49 \\
Transporte de insumos & 1 & 0,40 & 23,03 & 9,21 \\
Limpeza de terreno & 1 & 0,03 & 24,00 & 0,72 \\
Calagem & 1 & 0,08 & 24,00 & 1,92 \\
Plantio & 1 & 0,07 & 24,00 & 1,68 \\
Adubação cobertura & 1 & 0,11 & 24,00 & 2,64 \\
Aplicação formicida & 1 & 0,06 & 24,00 & 1,44 \\
Transporte insumos & 1 & 0,05 & 24,00 & 1,20 \\
Calcário & 1 & 3,00 & 42,00 & 126,00 \\
Super simples & 1 & 0,50 & 334,00 & 167,00 \\
Fertilizante 20-00-20 & 1 & 0,25 & 506,25 & 126,56 \\
Semente VC 20\% & 1 & 13,00 & 3,35 & 43,55 \\
Formicida & 1 & 1,00 & 6,68 & 6,68 \\
Total & & & & 768,41 \\
\hline
\end{tabular}

O valor total para formação da pastagem foi de $\mathrm{R} \$ 79.107,81$. Na implantação do pastejo rotacionado, existe a necessidade das divisões dos piquetes; em 36 piquetes, com cerca interna elétrica, kit de cerca elétrica (painel solar, isoladores, cabo e porteiras de molas), cerca radial elétrica e cerca externa elétrica. $\mathrm{O}$ espaçamento entre postes e o número de fíos elétricos para cada tipo de cerca foram estabelecidos de acordo com o padrão da instalação. Os valores para a implantação da cerca elétrica estão apresentados na Tabela 7. 
Tabela 7. Custo da cerca elétrica, com uma vida útil de 10 anos, para uma área de 102,95 ha, divididos em 36 piquetes.

\begin{tabular}{lccc}
\hline Descrição & Qde. $(\mathrm{m})$ & V. unitário $\left(\mathrm{R} \$ \mathrm{~m}^{-1}\right)$ & Valor total $(\mathrm{R} \$)$ \\
\hline Cerca radial elétrica & 18552,24 & 1,24 & 23054,69 \\
Cerca externa elétrica & 3595,93 & 1,95 & 7011,86 \\
Cerca interna eletrica & 359,59 & 2,00 & 720,00 \\
kit cerca elétrica (painel solar e etc) & 1 & 4780,00 & 4780,00 \\
Total & & & $35.565,53$ \\
\hline
\end{tabular}

\subsubsection{Custo da Mão-de-obra}

Para o manejo do sistema de pastejo rotacionado, são necessários 2 funcionários, um para a lida com o animais e o outro para o manejo do sistema, pagando-se um salário médio de trabalhador rural especializado mais 97,27\% de encargos, totalizando o valor de $\mathrm{R} \$ 19.397,08$ por ano (folha de pagamento + encargos sociais).

\subsubsection{Custos variáveis}

A participação dos custos variáveis depende do nível de manejo que se utiliza no sistema de pastagem irrigada, sendo os principais: energia elétrica, adubação de manutenção e despesas com os animais (sal mineral, vacinas, controle da mosca e vermífugos), como pode ser observado na Tabela 8.

Os custos variáveis de manutenção e reparos dos equipamentos e da infraestrutura utilizada na operação do sistema foram calculados de acordo com metodologia proposta por Franke (1998).

O capital investido para a compra dos animais será contabilizado como custos variáveis, porque a lotação de animais pode variar no sistema como a taxa de oportunidade do capital investido também pode estar variando de acordo com o mercado financeiro do país. Essa está taxa de oportunidade foi considerada de $5 \%$ ao ano. 
Tabela 8. Custos variáveis do manejo de pastagem irrigada e adubada e pastagem de sequeiro adubada, levando-se em consideração as despesas com, adubação e custeio anual dos animais.

\begin{tabular}{lcc}
\hline Descrição & Irrigado (R\$) & Sequeiro (R\$) \\
\hline Adubação nitrogênio $600 \mathrm{~kg} \mathrm{~N} \mathrm{ha}^{-1} \mathrm{ano}^{-1}$ & $20.816,78$ & $20.816,78$ \\
Adubação potássio $150 \mathrm{~kg} \mathrm{~K} \mathrm{ha}^{-1} \mathrm{ano}^{-1}$ & $7.721,36$ & $7.721,36$ \\
Energia elétrica $\left(\mathrm{R} \$ \mathrm{ano}^{-1}\right)$ & $20.428,94$ & 0,00 \\
Custeio dos animais $\left(\mathrm{R} \$ \mathrm{ano}^{-1}\right)$ & $26.475,88$ & $16.785,83$ \\
Total & $75.442,96$ & $45.323,97$ \\
\hline
\end{tabular}

$\mathrm{O}$ custo de energia elétrica apresentado na Tabela 8, refere-se à cidade de Aragarças - GO e o valor de R\$14.785,73 (Tabela 9) refere-se a cidade de Piracicaba SP.

\subsubsection{Simulação de viabilidade econômica da irrigação em pastagem}

Realizou-se um estudo econômico em bovinocultura de corte, avaliando-se a viabilidade da produção de pastagem de capim tanzânia irrigado e de sequeiro. Foi considerada para parâmetros da avaliação, a recria de animais machos com entrada no sistema dos animais com peso médio de $210 \mathrm{~kg}$ de peso vivo (PV) e saída com $340 \mathrm{Kg}$ de PV e preço de compra do bezerro $\mathrm{R} \$ 300,00$. Todas as simulações foram realizadas sem considerar o preço da terra.

Nas simulações efetuadas, simulou-se as seguintes variáveis: ganho de peso diário dos animais $(0,50,0,75$ e 1,00 Kg de PV ao dia), níveis de adubação (300, 600 e $900 \mathrm{~kg} \mathrm{~N} \mathrm{ha}{ }^{-1} \mathrm{ano}^{-1}$ ), preço de venda da arroba (35, 40 e 45 R\$/@).

Os dados de temperatura e de precipitação pluviométrica utilizados são uma média histórica das condições climatológicas das regiões estudadas e foram extraídos do software Balanço Hídrico - BRASIL (Sentelhas et al. 1999). As cidades escolhidas para este estudo foram: Piracicaba - SP, sede da área experimental, e Aragarças - GO. As condições climáticas desses municípios são apresentas nas Figuras 11 e 12. 


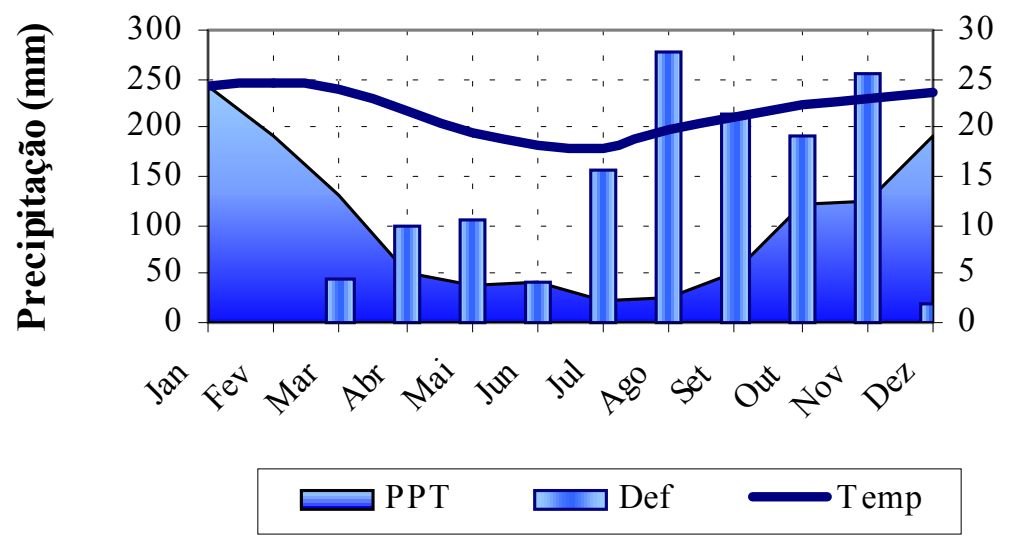

ఏ્छ

Figura 11 - Características climáticas da região de Piracicaba - SP (Latitude $22^{\circ} 33^{\prime}$ S, Longitude $47^{\circ} 43^{\prime} \mathrm{W}$ e Longitude $47^{\circ} 43^{\prime} \mathrm{W}$ ) e $490 \mathrm{~m}$ de altitude.

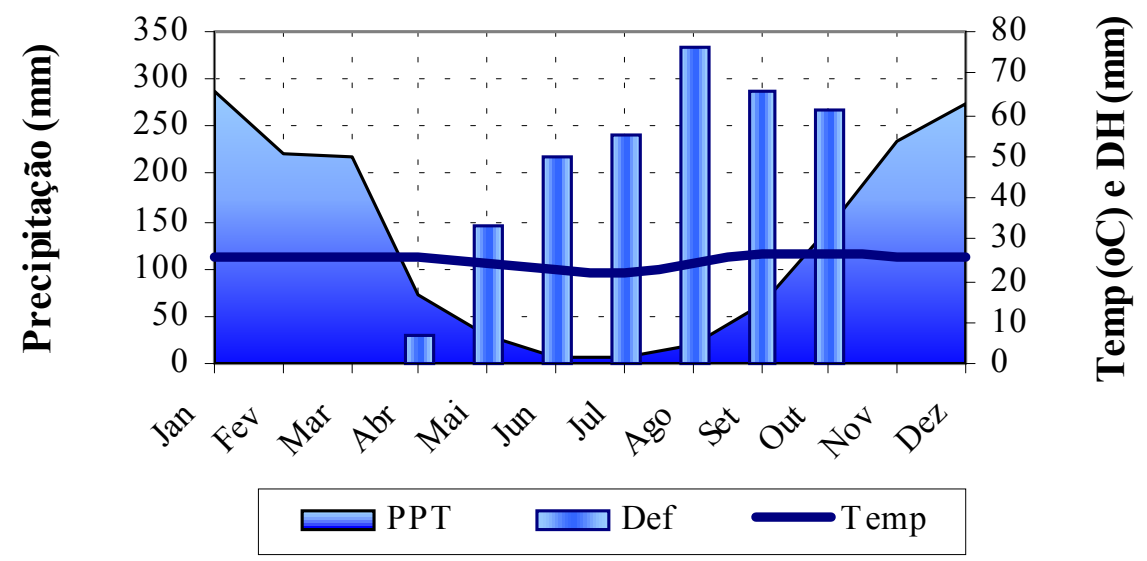

Figura 12 - Características climáticas da região de Aragarças - GO (Latitude $15^{\circ} 54^{\prime}$ S, Longitude $52^{\circ} 13^{\prime} \mathrm{W}$ ) e $345 \mathrm{~m}$ de altitude.

Nas Tabelas 9 e 10, são apresentados as lâminas de irrigação mensal e total para suprir a necessidade do capim tanzânia, e o custo com energia elétrica, nas regiões estudadas, conforme a deficiência hídrica determinada pelo balanço hídrico climatológico calculado. 
Tabela 9. Lâminas de irrigação e custo elétrico $\left(\mathrm{R} \$\right.$ mês $\left.^{-1}\right)$ na área irrigada na região de Piracicaba - SP.

\begin{tabular}{lcccc}
\hline \multicolumn{1}{c}{ Mês } & $\begin{array}{c}\text { Necessidade de } \\
\text { irrigação }(\mathrm{mm})\end{array}$ & $\begin{array}{c}\text { Horas de } \\
\text { trabalhos (horas) }\end{array}$ & $\begin{array}{c}\text { Energia } \\
\text { requerida }(\mathrm{kWh})\end{array}$ & $\begin{array}{c}\text { Custo da energia } \\
\left(\mathrm{R} \$ \text { mês }^{-1}\right)\end{array}$ \\
\hline Janeiro & 0,00 & 0,0 & 0,0 & 728,67 \\
Fevereiro & 0,00 & 0,0 & 0,0 & 728,67 \\
Março & 31,46 & 94,4 & 114,2 & 1551,49 \\
Abril & 27,34 & 82,0 & 99,2 & 1443,77 \\
Maio & 21,28 & 63,8 & 77,2 & 1285,31 \\
Junho & 7,11 & 21,3 & 25,8 & 914,67 \\
Julho & 24,91 & 74,7 & 90,4 & 1380,17 \\
Agosto & 38,27 & 114,8 & 138,9 & 1729,80 \\
Setembro & 26,70 & 80,1 & 96,9 & 1427,19 \\
Outubro & 22,63 & 67,9 & 82,1 & 1320,50 \\
Novembro & 28,99 & 87,0 & 105,2 & 1486,85 \\
Dezembro & 2,29 & 6,9 & 8,3 & 788,65 \\
Total & 230,98 & 692,9 & & $14.785,73$ \\
\hline
\end{tabular}

Tabela 10. Lâminas de irrigação e custo elétrico $\left(\mathrm{R} \$\right.$ mês $\left.^{-1}\right)$ da área irrigada na região Aragarças - GO.

\begin{tabular}{lcccc}
\hline \multicolumn{1}{c}{ Mês } & $\begin{array}{c}\text { Necessidade de } \\
\text { irrigação }(\mathrm{mm})\end{array}$ & $\begin{array}{c}\text { Horas de trabalhos } \\
\text { (horas) }\end{array}$ & $\begin{array}{c}\text { Energia requerida } \\
(\mathrm{kWh})\end{array}$ & $\begin{array}{c}\text { Custo da energia } \\
\left(\mathrm{R} \$ \text { mês }^{-1}\right)\end{array}$ \\
\hline Janeiro & 0,00 & 0,0 & 0,0 & 728,67 \\
Fevereiro & 0,00 & 0,0 & 0,0 & 728,67 \\
Março & 0,00 & 0,0 & 0,0 & 728,67 \\
Abril & 39,05 & 117,1 & 141,7 & 1750,06 \\
Maio & 66,38 & 199,1 & 240,9 & 2465,03 \\
Junho & 66,65 & 200,0 & 241,9 & 2472,07 \\
Julho & 63,33 & 190,0 & 229,9 & 2385,17 \\
Agosto & 81,44 & 244,3 & 295,6 & 2858,81 \\
Setembro & 67,49 & 202,5 & 245,0 & 2494,03 \\
Outubro & 62,38 & 187,1 & 226,4 & 2360,44 \\
Novembro & 0,00 & 0,0 & 0,0 & 728,67 \\
Dezembro & 0,00 & 0,0 & 0,0 & 728,67 \\
Total & 446,72 & 1340,2 & & $20.428,94$ \\
\hline
\end{tabular}

Conforme as características climáticas das regiões, estimou-se através do modelo proposto, a produtividade do capim tanzânia irrigado e de sequeiro, submetido a uma adubação anual de $600 \mathrm{~kg} \mathrm{~N} \mathrm{ha}^{-1} \mathrm{ano}^{-1}$. As Figuras 13 e 14 apresentam a 
distribuição da produtividade ao longo do ano, e a Tabela 11, apresenta a produção total anual para as adubações de 300,600 e $900 \mathrm{~kg} \mathrm{~N} \mathrm{ha}^{-1} \mathrm{ano}^{-1}$.

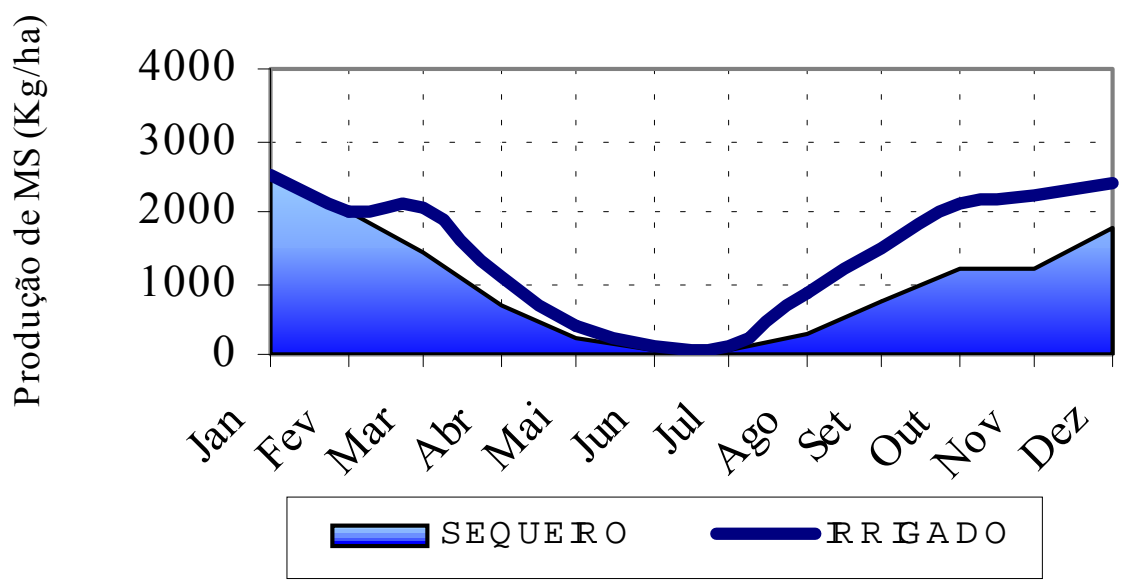

Figura 13 - Produção de MS do capim tanzânia, ao longo do ano, para a região de Piracicaba - SP, com adubação de $600 \mathrm{~kg} \mathrm{~N} \mathrm{ha}^{-1} \mathrm{ano}^{-1}$.

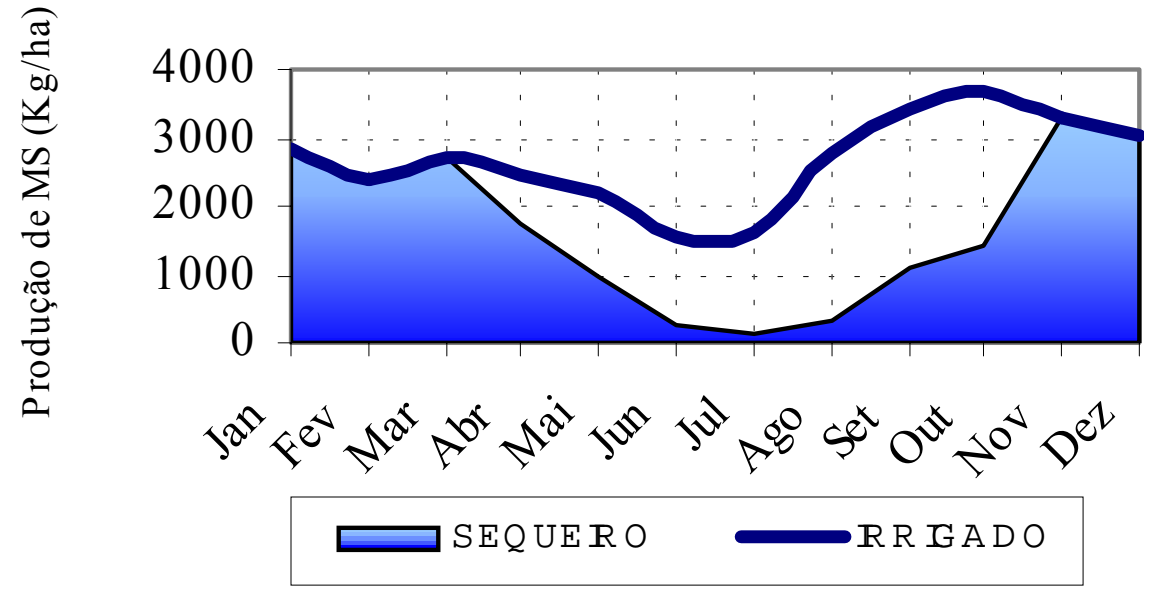

Figura 14 - Produção de MS do capim tanzânia, ao longo do ano, para a região de Aragarças - GO, com adubação de $600 \mathrm{~kg} \mathrm{~N} \mathrm{ha}^{-1} \mathrm{ano}^{-1}$. 
Tabela 11. Produção total do capim tanzânia $\mathrm{kg} \mathrm{MS} \mathrm{ha}^{-1} \mathrm{ano}^{-1}$ com adubação de 300, 600 e $900 \mathrm{~kg} \mathrm{~N} \mathrm{ha}^{-1} \mathrm{ano}^{-1}$.

\begin{tabular}{ccccc}
\hline & \multicolumn{2}{c}{ Piracicaba } & \multicolumn{2}{c}{ Aragarças } \\
\hline $\begin{array}{c}\text { Adubação em } \\
\left(\mathrm{kg} \mathrm{N} \mathrm{ha}^{-1} \mathrm{ano}^{-1}\right)\end{array}$ & $\begin{array}{c}\text { Irrigado } \\
\left(\mathrm{kg} \mathrm{MS} \mathrm{ha}^{-1} \mathrm{ano}^{-1}\right)\end{array}$ & $\begin{array}{c}\text { Sequeiro } \\
\left(\mathrm{kg} \mathrm{MS} \mathrm{ha}^{-1} \mathrm{ano}^{-1}\right)\end{array}$ & $\begin{array}{c}\text { Irrigado } \\
\left(\mathrm{kg} \mathrm{MS} \mathrm{ha}^{-1} \mathrm{ano}^{-1}\right)\end{array}$ & $\begin{array}{c}\text { sequeiro } \\
\left(\mathrm{kg} \mathrm{MS} \mathrm{ha}^{-1} \mathrm{ano}^{-1}\right)\end{array}$ \\
\hline 300 & 15942,60 & 11275,15 & 29265,20 & 18483,20 \\
600 & 17385,98 & 12295,96 & 31914,76 & 20156,60 \\
900 & 18581,53 & 13141,49 & 34784,64 & 21542,67 \\
\hline
\end{tabular}

Observou-se que a produção de matéria seca na região de Piracicaba - SP não teve um aumento significativo, devido à temperatura do ar e ao fotoperíodo restritivos, já a irrigação teve pouca influência nessa região, pois houve um bom índice de precipitação que supre quase que totalmente o déficit hídrico do capim tanzânia no período mais quente do ano, sendo portanto este aumento mais influenciado pelas altas doses de adubação nitrogenada. A temperatura do ar e o fotoperíodo contribuíram para aumentar a estacionalidade de produção do capim tanzânia, como mostrado na Tabela 11.

Na região de Aragarças - GO, a produção de MS aumentou com a elevação da dose de adubação nitrogenada e com a irrigação, sendo essa diferença de bastante significância, quando comparada à produção de MS da pastagem de sequeiro adubada.

Ao se compararem as duas regiões estudadas, verificou-se uma diferença bastante significativa de produções de MS do capim tanzânia, sendo isso explicado pelas diferenças de temperaturas do ar e do fotoperíodo nas regiões.

Nas Figuras 15 e 16, são apresentadas as análises de sensibilidade do sistema pastagem irrigada, comparando-se as regiões de Piracicaba - SP e Aragarças- GO, tendo sido simulados os seguintes fatores: ganho de peso diário dos animais $(0,50 ; 0,75$ e 1,00 $\mathrm{kg}$ de PV dia $\left.{ }^{-1}\right)$, níveis de adubação $\left(300,600\right.$ e $900 \mathrm{~kg} \mathrm{~N}^{-1}$ ano $\left.^{-1}\right)$, preço de venda da arroba (35, 40 e $45 \mathrm{R} \$ / @)$. 


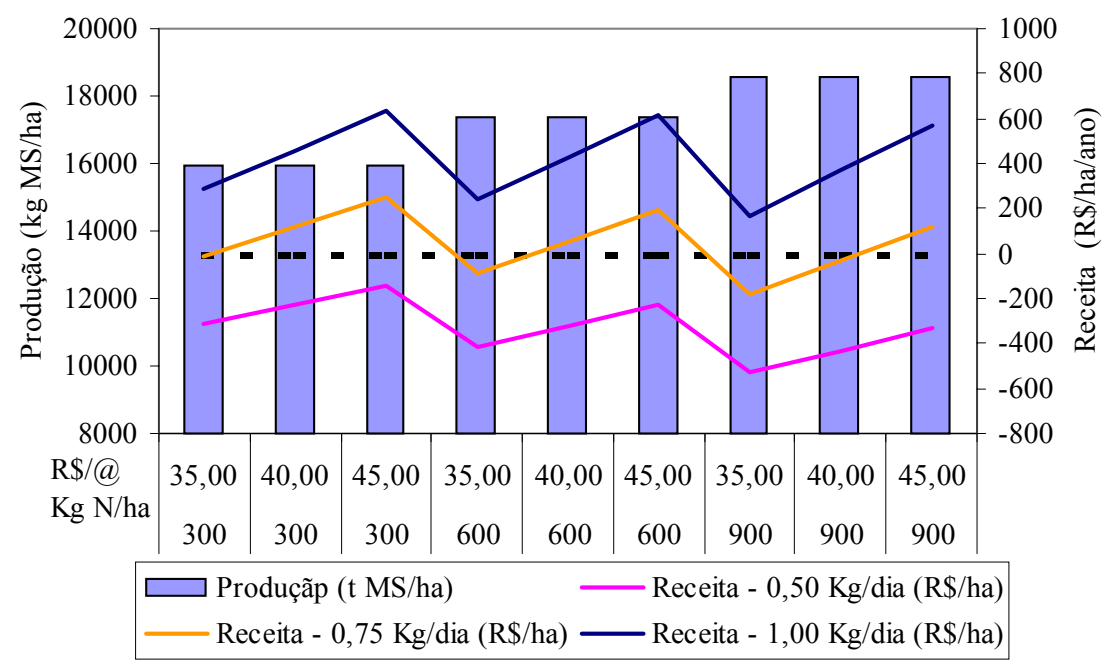

Figura 15 - Estudo da viabilidade de pastagem irrigada para Piracicaba-SP, simulando os seguintes fatores: ganho de peso diário dos animais $(0,50 ; 0,75 \mathrm{e} \mathrm{1,00} \mathrm{\textrm {kg }}$ de PV dia $\left.{ }^{-1}\right)$, níveis de adubação $\left(300,600\right.$ e $\left.900 \mathrm{~kg} \mathrm{~N} \mathrm{ha}^{-1} \mathrm{ano}^{-1}\right)$, preço de venda da arroba (35, 40 e 45 R\$/@).

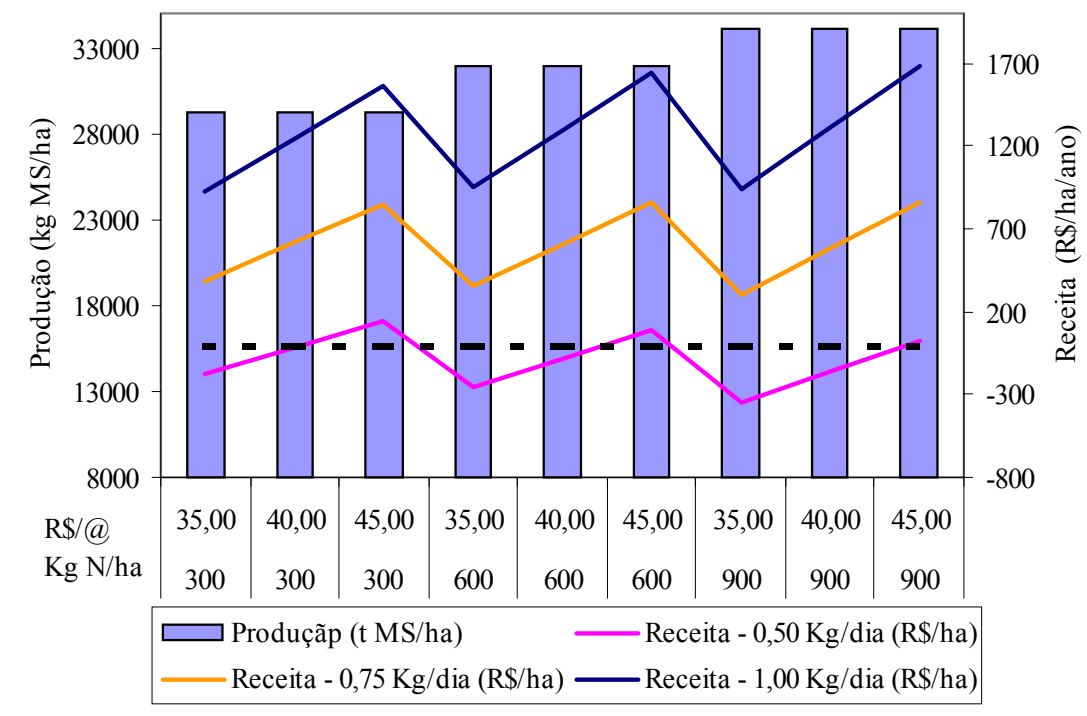

Figura 16 - Estudo da viabilidade de pastagem irrigada para Aragarças - GO, simulando os seguintes fatores: ganho de peso diário dos animais $(0,50 ; 0,75$ e $1,00 \mathrm{~kg}$ de PV dia $\left.{ }^{-1}\right)$, níveis de adubação $\left(300,600\right.$ e $900 \mathrm{~kg} \mathrm{~N}^{-1}$ ano $\left.^{-1}\right)$, preço de venda da arroba (35, 40 e 45 R\$/@). 
Nas regiões avaliadas, observa-se que em Piracicaba - SP, a pastagem irrigada apresentou melhor desempenho com o GPD de $0,75 \mathrm{~kg}$ de PV dia ${ }^{-1}$ e uma adubação de $300 \mathrm{~kg} \mathrm{~N} \mathrm{ha}{ }^{-1}$ ano $^{-1}$ com o preço de venda da arroba de $\mathrm{R} \$ 45,00$, apresentando uma rentabilidade em torno de $\mathrm{R} \$ 245,48 \mathrm{ha}^{-1} \mathrm{ano}^{-1}$, para o manejo recria, segundo o qual os animais apresentam uma maior conversão alimentar, garantindo a lucratividade do sistema.

Em Aragarças - GO, a pastagem irrigada apresentou melhor desempenho com GPD acima de $0,75 \mathrm{~kg}$ de PV dia ${ }^{-1}$, com uma adubação de $600 \mathrm{~kg} \mathrm{~N} \mathrm{ha}^{-1}$ ano $^{-1}$ com o preço de venda da arroba de $\mathrm{R} \$ 45,00$, tendo uma rentabilidade em torno de $\mathrm{R} \$ 865,39$ $\mathrm{ha}^{-1} \mathrm{ano}^{-1}$. As condições climáticas melhoram os resultados da região de Aragarças GO, como uma maior produtividade de matéria seca por área, elevando-se a lotação e diminuindo-se a estacionalidade de produção das gramíneas.

Com base na análise dos dados, pode-se observar que a irrigação de pastagem é uma ferramenta complementar ao pecuarista, para otimizar a produção anual de matéria seca na propriedade. As vantagens acentuam-se em regiões mais próximas ao equador, e também em regiões onde a água é fator limitante para o crescimento da pastagem em determinados períodos do ano (déficit hídrico sazonal). A implantação de um sistema mecanizado de irrigação de pastagens exige um estudo mais aprofundado de viabilidade econômica do empreendimento e dos requerimentos tecnológicos exigidos nesse tipo de exploração pecuária.

Nas Figuras 17 e 18, são apresentadas as análises de sensibilidade do sistema pastagem de sequeiro, para as regiões de Piracicaba - SP e Aragarças- GO, para as seguintes variáveis: ganho de peso diário dos animais $\left(0,50 ; 0,75\right.$ e 1,00 Kg de PV dia $\left.{ }^{-1}\right)$, níveis de adubação $\left(300,600\right.$ e $\left.900 \mathrm{~kg} \mathrm{~N} \mathrm{ha}^{-1} \mathrm{ano}^{-1}\right)$, preço de venda da arroba $(35,40$ e 45R\$/@). 


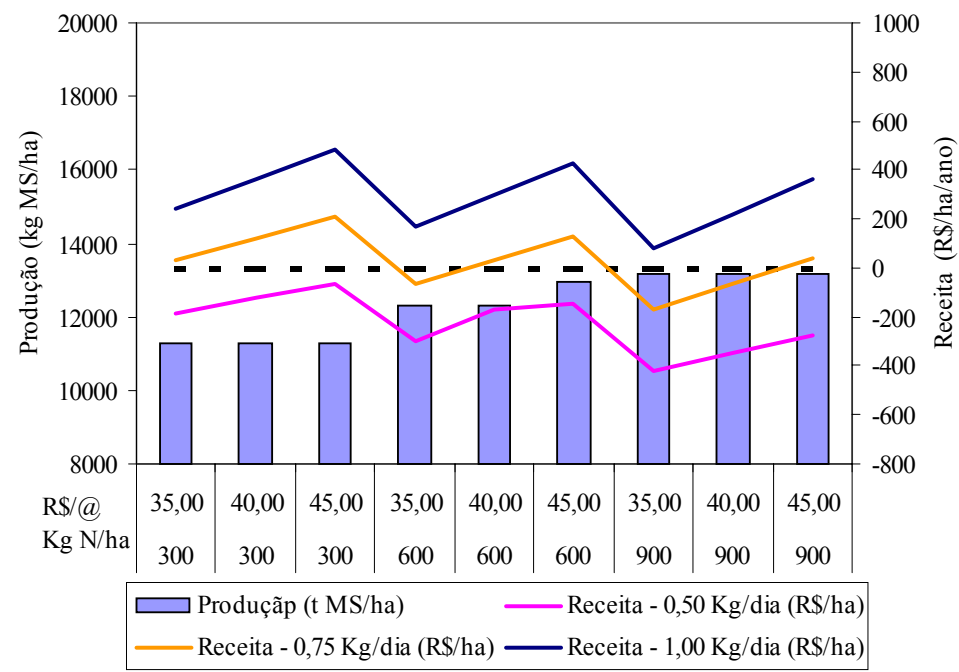

Figura 17 - Estudo da viabilidade de pastagem de sequeiro para Piracicaba - SP, simulando-se os seguintes fatores: ganho de peso diário dos animais $\left(0,50 ; 0,75\right.$ e 1,00 kg de PV dia $\left.{ }^{-1}\right)$, níveis de adubação (300, 600 e $900 \mathrm{~kg}$ $\mathrm{N} \mathrm{ha}^{-1}$ ano $\left.^{-1}\right)$, preço de venda da arroba $(35,40$ e $45 \mathrm{R} \$ / @)$.

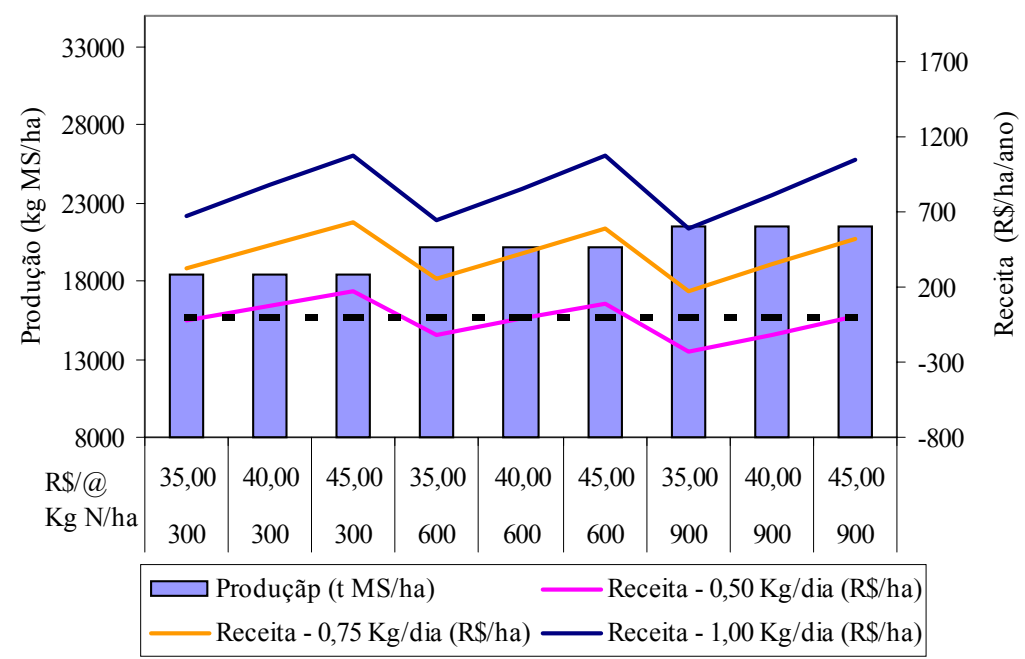

Figura 18 - Estudo da viabilidade de pastagem de sequeiro para Aragarças - GO, simulando-se os seguintes fatores: ganho de peso diário dos animais $\left(0,50,0,75\right.$ e 1,00 kg de PV dia $\left.{ }^{-1}\right)$, níveis de adubação (300, 600 e $900 \mathrm{~kg}$ $\mathrm{N} \mathrm{ha}^{-1}$ ano $\left.^{-1}\right)$, preço de venda da arroba (35, 40 e 45 R\$/@). 
Em Piracicaba -SP, a pastagem de sequeiro apresentou desempenho melhor com o GPD de $0,75 \mathrm{~kg}$ de PV dia ${ }^{-1}$ e uma adubação de $300 \mathrm{~kg} \mathrm{~N} \mathrm{ha}^{-1}$ ano $^{-1}$ com o preço de venda da arroba de $\mathrm{R} \$ 45,00$. A rentabilidade ficou em torno de $\mathrm{R} \$ 211,63 \mathrm{ha}^{-1} \mathrm{ano}^{-1}$, sendo que o GPD de $0,50 \mathrm{~kg}$ de $\mathrm{PV}$ dia $^{-1}$ não apresentou receita positiva, por elevação dos custos de produção. A pastagem de sequeiro, na região de Aragarças - GO, apresentou desempenho melhor, com GPD acima de $0,75 \mathrm{~kg}$ de PV dia ${ }^{-1}$, com uma adubação de $300 \mathrm{~kg} \mathrm{~N} \mathrm{ha}^{-1}$ ano $^{-1}$ com o preço de venda da arroba de $\mathrm{R} \$ 45,00$. A rentabilidade ficou em torno de $\mathrm{R} \$ 624,70 \mathrm{ha}^{-1} \mathrm{ano}^{-1}$, em função da maior produtividade de matéria seca por área e maior capacidade de lotação em UA ha ${ }^{-1}$.

Comparando-se as duas regiões estudadas, observa-se que a região de Piracicaba - SP apresenta uma produção de MS menor em todos os níveis de adubação nitrogenada, em relação a Aragarças - GO; isso em função das condições climáticas (fotoperíodo e temperatura) mais limitantes para o capim tanzânia.

Com relação à diminuição da estacionalidade da produção com a irrigação das pastagens, podemos observar que a técnica não é eficiente em regiões com invernos rigorosos, sendo o caso de Piracicaba - SP.

Nas Figuras 19 e 20, são apresentadas as análises de sensibilidade do sistema pastagem irrigada, comparando-se as regiões de Piracicaba - SP e Aragarças- GO, foram simulados os seguintes fatores: ganho de peso diário dos animais $(0,50 ; 0,75$ e $1,00 \mathrm{~kg}$ de PV dia $\left.{ }^{-1}\right)$, nível de adubação $600 \mathrm{~kg} \mathrm{~N} \mathrm{ha}^{-1} \mathrm{ano}^{-1}$, preço de venda da arroba $(35,40 \mathrm{e}$ $45 \mathrm{R} \$(@)$, para três tipos de manejo dos animais: recria, recria/engorda e engorda, mostrando-se a rentabilidade em $\mathrm{R} \$ \mathrm{ha}^{-1} \mathrm{ano}^{-1}$ para cada tipo de manejo. O peso de entrada dos animais para recria é $210 \mathrm{~kg}$ de PV e peso de saída $320 \mathrm{~kg}$ de PV, preço de compra do bezerro $\mathrm{R} \$ 300,00$; o peso de entrada dos animais para recria/engorda é 210 $\mathrm{kg}$ de PV e peso de saída $440 \mathrm{~kg}$ de PV; para engorda, o peso de entrada é $320 \mathrm{~kg}$ de PV e peso de saída $440 \mathrm{~kg}$ de $\mathrm{PV}$, preço de compra do boi magro $\mathrm{R} \$ 410,00$. 


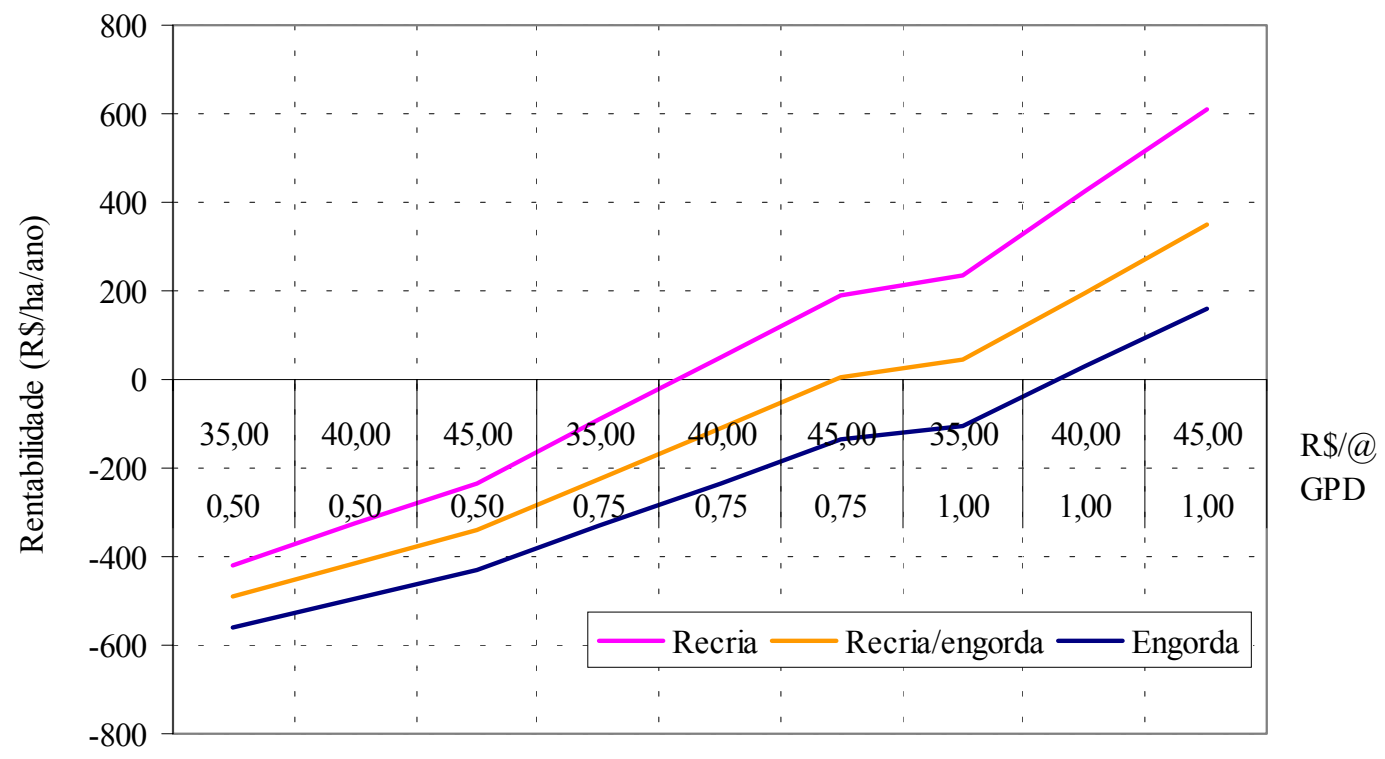

Figura 19 - Rentabilidade da pastagem irrigada para Piracicaba - SP, simulando-se os seguintes fatores: ganho de peso diário dos animais, nível de adubação, preço de venda da arroba e tipo de manejo dos animais.

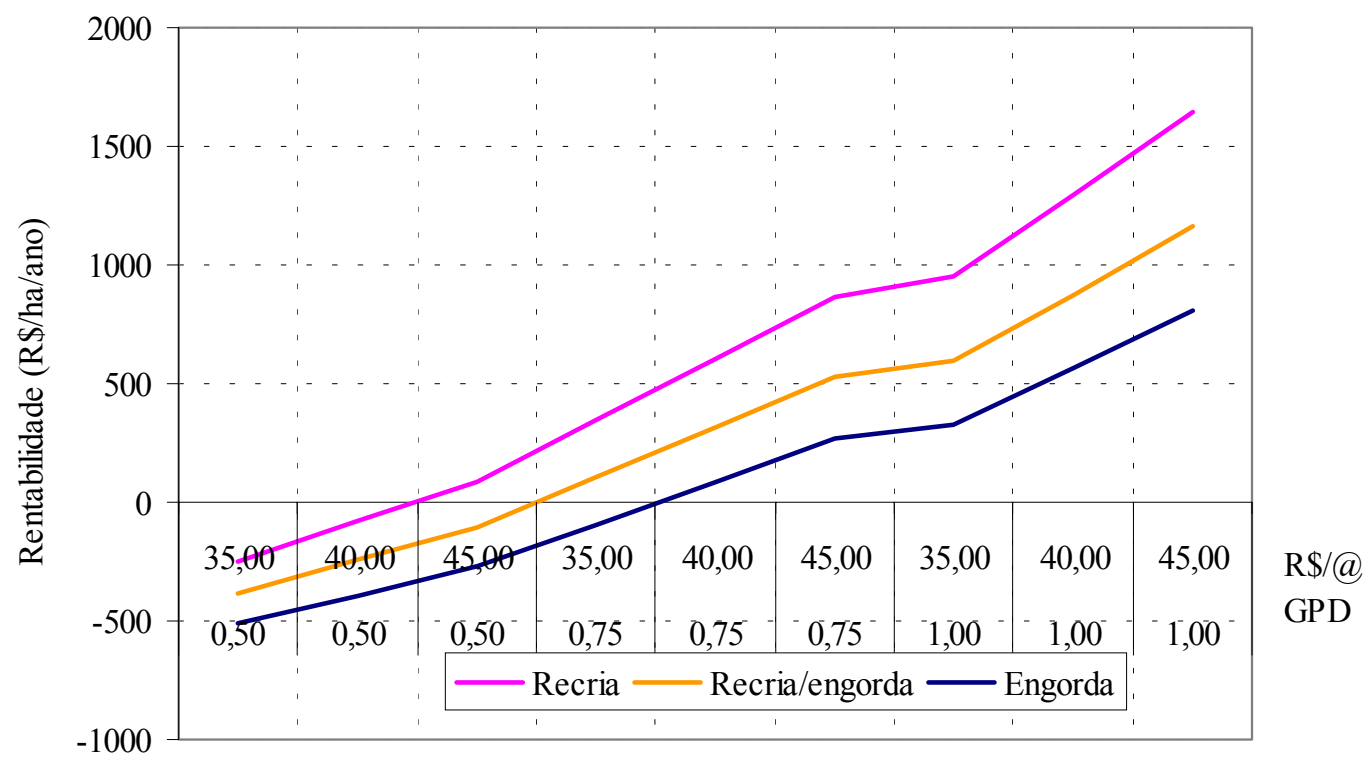

Figura 20 - Rentabilidade da pastagem irrigada para Aragarças - GO, simulando-se os seguintes fatores: ganho de peso diário dos animais, nível de adubação, preço de venda da arroba e tipo de manejo dos animais. 
Comparando-se as rentabilidades da pastagem irrigada para os três tipos de manejos, nota-se que os resultados de rentabilidade variam em função do preço da arroba e do ganho de peso vivo diário para cada tipo de manejo. Com base na análise dos gráficos na região de Piracicaba - SP, conclui-se que: 1) a recria tem rentabilidade positiva com ganho de peso vivo acima de $0,75 \mathrm{~kg} \mathrm{dia}^{-1}$, preço de venda da arroba $\mathrm{R} \$$ 40,00 e lucro de $\mathrm{R} \$ 48,86$ ha $\mathrm{ano}^{-1}$, 2) a engorda tem rentabilidade positiva com ganho de peso vivo acima de $1,00 \mathrm{~kg} \mathrm{dia}^{-1}$, preço de venda da arroba $\mathrm{R} \$ 40,00$ e lucro de $\mathrm{R} \$$ 28,17 ha $^{-1}$ e 3 ) a recria/engorda tem-se a rentabilidade positiva com ganho de peso vivo acima de $0,75 \mathrm{~kg} \mathrm{dia}^{-1}$, preço de venda da arroba $\mathrm{R} \$ 45,00$ e lucro de $\mathrm{R} \$ 5,69$ ha ano $^{-1}$. Tanto para a recria/engorda como a engorda, há um risco elevado de insucesso por se tratar de ganho de peso vivo muito alto para bovinos em terminação, com um ganho de peso vivo em torno de 0,40 a $0,50 \mathrm{~kg} \mathrm{dia}^{-1}$.

Na região de Aragarças - GO, as rentabilidades nos três tipos de manejo foram melhores do que em de Piracicaba - SP: a recria tem rentabilidade com ganho de peso vivo acima de $0,50 \mathrm{~kg} \mathrm{dia}^{-1}$, preço de venda da arroba $\mathrm{R} \$ 45,00$ e lucro de $\mathrm{R} \$ 90,57$ ha ano $^{-1}$; na recria/engorda tem-se a rentabilidade com ganho de peso vivo acima de 0,75 $\mathrm{kg} \mathrm{dia}{ }^{-1}$, preço de venda da arroba $\mathrm{R} \$ 35,00$ e lucro de $\mathrm{R} \$ 106,45$ ha ano $^{-1}$ e engorda com a rentabilidade com ganho de peso vivo acima de $0,75 \mathrm{~kg} \mathrm{dia}^{-1}$, preço de venda da arroba R $\$ 40,00$ e lucro de $\mathrm{R} \$ 88,56$ ha $\mathrm{ano}^{-1}$.

Nas regiões avaliadas de Piracicaba - SP e Aragarças - GO, as rentabilidades são melhores na recria, sendo a lucratividade maior em Aragarças - GO, com ganho de peso vivo de $1,00 \mathrm{~kg}$ ao dia, preço de venda da arroba $\mathrm{R} \$ 45,00$ e lucro de $\mathrm{R} \$ 1640,22$ ha ano $^{-1}$, já em Piracicaba - SP, o lucro máximo deu-se a um ganho de peso vivo de 1,00 $\mathrm{kg}$ ao dia, preço de venda da arroba $\mathrm{R} \$ 45,00$ e lucro de $\mathrm{R} \$ 611,66$ ha ano ${ }^{-1}$.

Nas Figuras 21 e 22, são apresentadas as análises de sensibilidade do sistema pastagem de sequeiro, comparando-se as regiões de Piracicaba - SP e Aragarças- GO, onde foram seguidas as mesmas simulações anteriores. 


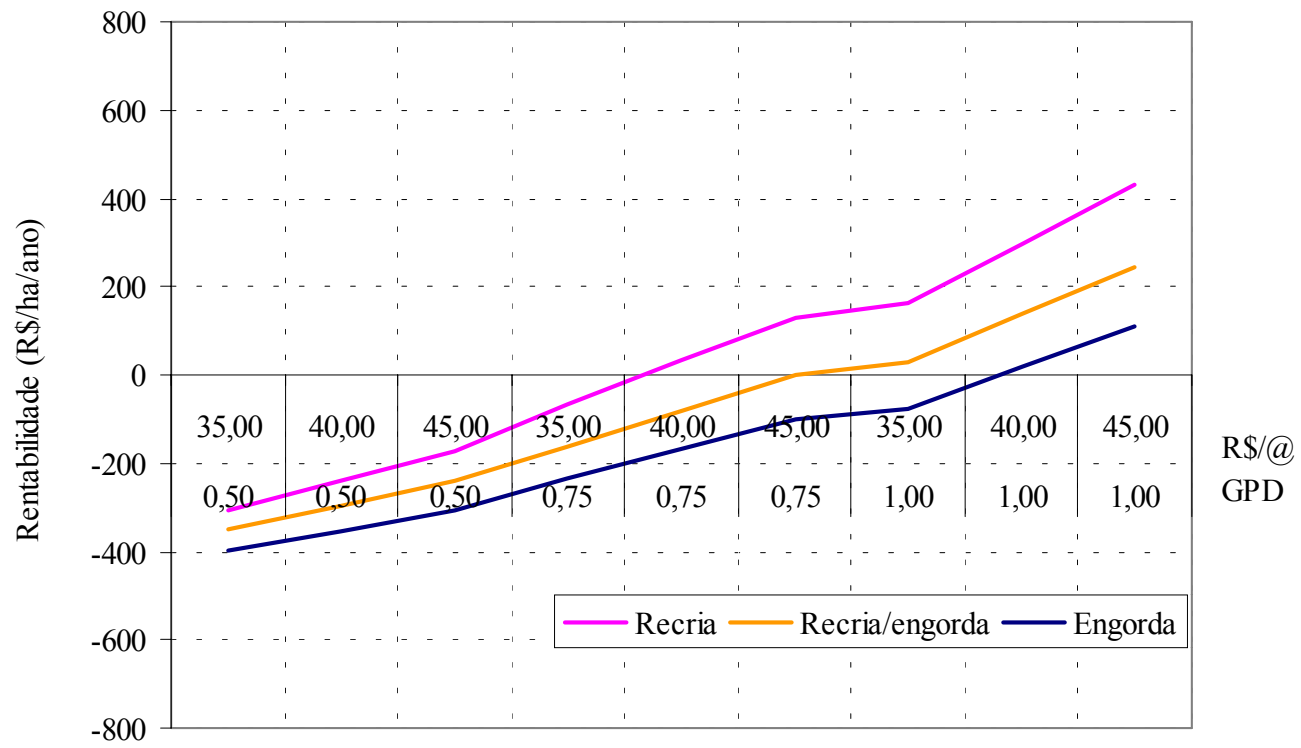

Figura 21 - Rentabilidade da pastagem de sequeiro para Piracicaba - SP, simulando-se os seguintes fatores: ganho de peso diário dos animais, nível de adubação, preço de venda da arroba e tipo de manejo dos animais.

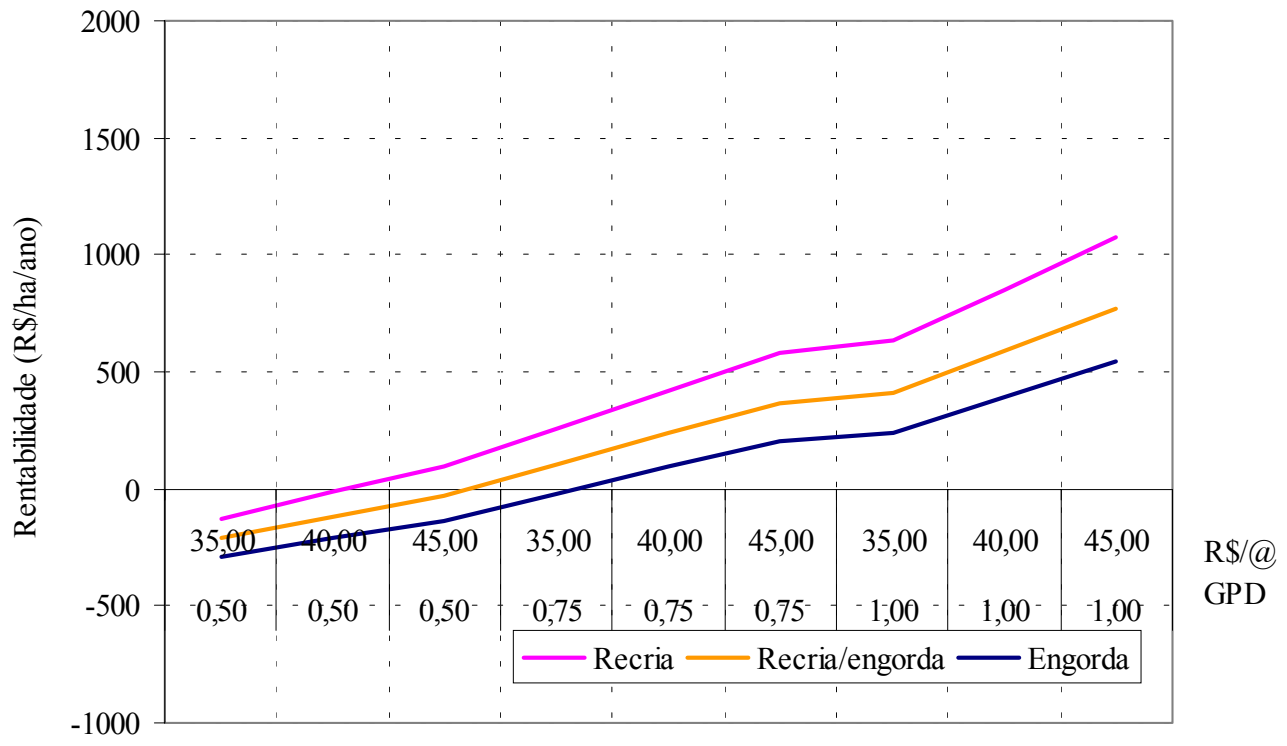

Figura 22 - Rentabilidade da pastagem de sequeiro para Aragarças - GO, simulando-se os seguintes fatores: ganho de peso diário dos animais, nível de adubação, preço de venda da arroba e tipo de manejo dos animais. 
Avaliando-se a rentabilidades da pastagem de sequeira para os três tipos de manejo estudados (recria, recria/engorda e engorda), variam em função do preço da arroba e do ganho de peso vivo. Com base na análise dos gráficos na região de Piracicaba - SP, na recria tem rentabilidade com ganho de peso vivo acima de 0,75 $\mathrm{kg}$ dia $^{-1}$, preço de venda da arroba $\mathrm{R} \$ 40,00$ e lucro de $\mathrm{R} \$ 31,95$ ha ano ${ }^{-1}$; na recria/engorda, tem-se a rentabilidade com ganho de peso vivo acima de $0,75 \mathrm{~kg} \mathrm{dia}^{-1}$, preço de venda da arroba $\mathrm{R} \$ 45,00$ e lucro de $\mathrm{R} \$ 1,52$ ha ano ${ }^{-1}$ e engorda com a rentabilidade com ganho de peso vivo acima de $1,00 \mathrm{~kg} \mathrm{dia}^{-1}$, preço de venda da arroba $\mathrm{R} \$ 40,00$ e lucro de $\mathrm{R} \$ 17,44$ ha ano $^{-1}$. O manejo mais apropriado foi a recria, com o GPD acima de $0,75 \mathrm{~kg} \mathrm{dia}^{-1}$ e o preço de venda da arroba acima de $\mathrm{R} \$ 40,00$.

$\mathrm{Na}$ região de Aragarças - GO, as rentabilidades nos três tipos de manejo se saíram melhor que as de Piracicaba - SP, onde na recria tem rentabilidade com ganho de peso vivo acima de $0,50 \mathrm{~kg} \mathrm{dia}^{-1}$, preço de venda da arroba $\mathrm{R} \$ 45,00$ e lucro de $\mathrm{R} \$ 92,57$ ha ano $^{-1}$, na recria/engorda tem-se à rentabilidade com ganho de peso vivo acima de 0,75 $\mathrm{kg} \mathrm{dia}^{-1}$, preço de venda da arroba $\mathrm{R} \$ 35,00$ e lucro de $\mathrm{R} \$ 102,45$ ha $\mathrm{ano}^{-1}$ e na engorda com a rentabilidade com ganho de peso vivo acima de $0,75 \mathrm{~kg} \mathrm{dia}^{-1}$, preço de venda da arroba $\mathrm{R} \$ 40,00$ e lucro de $\mathrm{R} \$ 91,56$ ha ano ${ }^{-1}$.

Para as regiões avaliadas de Piracicaba - SP e Aragarças - GO, as rentabilidades são maiores na recria, sendo a lucratividade maior em Aragarças - GO, com ganho de peso vivo de $1,00 \mathrm{~kg}$ ao dia, preço de venda da arroba $\mathrm{R} \$ 45,00$ e lucro de $\mathrm{R} \$ 1071,29$ ha ano $^{-1}$, já em Piracicaba - SP o lucro máximo de R\$ 429,98 ha ano ${ }^{-1}$ se deu a um ganho de peso vivo de $1,00 \mathrm{~kg}$ ao dia, com o preço de venda da arroba de R\$ 45,00 .

A análise de custos comprovou a maior viabilidade do sistema de pastagem irrigada em Aragarças - GO, pois a condição climática se mostrou mais favorável para as plantas forrageiras, como o capim tanzânia. Em Piracicaba - SP, a prática não se mostra tão rentável, podendo ser inviável, devido ao grande tempo necessário para pagar o investimento. 


\subsubsection{Simulação de viabilidade econômica da irrigação em pastagem para várias regiões do Brasil}

Para alcançarem maiores índices de produtividade, pecuaristas tecnificados buscam alternativas para incrementar a produção de carne na propriedade e conseqüentemente, aumentar seus lucros. Com a irrigação das pastagens, o manejo da bovinocultura de corte torna-se mais seguro do que em um sistema tradicional de pastejo rotacionado. Sem as flutuações na produção, devido aos veranicos, o sistema torna-se mais estável, em regiões onde não há problemas de temperaturas e de fotoperíodo.

Foi realizado um estudo da viabilidade do sistema de pastagem irrigada e de sequeiro, para 25 municípios do Brasil, simulando-se os seguintes fatores: ganho de peso diário dos animais $0,75 \mathrm{~kg}$ de PV dia ${ }^{-1}$, o tipo de manejo recria, nível de adubação 600 $\mathrm{kg} \mathrm{N} \mathrm{ha}{ }^{-1} \mathrm{ano}^{-1}$, preço de venda da arroba $\mathrm{R} \$ 40,00$, lotação média de bovinos em UA ha ${ }^{-1}$, rentabilidade em $R \$ h^{-1} a^{-1}$, taxa interna de retorno (TIR) em porcentagem, como mostra a Tabela 12 . 
Tabela 12. Simulação da viabilidade econômica da pastagem irrigada e de sequeiro, para 25 municípios brasileiros.

\begin{tabular}{|c|c|c|c|c|c|c|c|c|}
\hline \multirow[b]{2}{*}{ Cidade } & \multicolumn{4}{|c|}{ PASTAGEM IRRIGADA } & \multicolumn{4}{|c|}{ PASTAGEM SEQUEIRO } \\
\hline & $\begin{array}{c}\text { Prod. de MS } \\
\left(\mathrm{kg} \mathrm{ha}^{-1} \text { ano }^{-1}\right)\end{array}$ & $\begin{array}{l}\text { Lot. média } \\
\left(\mathrm{UA} \mathrm{ha}^{-1}\right)\end{array}$ & $\begin{array}{c}\text { Receita } \\
\left(\mathrm{R} \$ \text { ha }^{-1} \mathrm{ano}^{-1}\right)\end{array}$ & TIR (\%) & $\begin{array}{l}\text { Prod. de MS } \\
\left(\mathrm{kg} \mathrm{ha}^{-1} \mathrm{ano}^{-1}\right)\end{array}$ & $\begin{array}{l}\text { Lot. média } \\
\left(\mathrm{UA} \mathrm{ha}^{-1}\right)\end{array}$ & $\begin{array}{c}\text { Receita } \\
\left(\mathrm{R} \$ \text { ha }^{-1} \mathrm{ano}^{-1}\right)\end{array}$ & TIR (\%) \\
\hline Piracicaba - SP & 17386,0 & 3,61 & 48,86 & 0,87 & 12296,0 & 2,56 & 31,95 & 1,30 \\
\hline Araçatuba - SP & 27105,0 & 5,62 & 364,07 & 5,41 & 13196,0 & 2,74 & 76,41 & 2,99 \\
\hline S. J. Rio Preto - SP & 25897,0 & 5,37 & 341,74 & 5,18 & 14875,0 & 3,10 & 158,58 & 5,76 \\
\hline Goiânia - GO & 24585,0 & 5,09 & 329,11 & 5,10 & 16796,0 & 3,49 & 253,89 & 8,57 \\
\hline Aragarças - GO & 31915,0 & 6,61 & 607,12 & 8,35 & 20157,0 & 4,19 & 418,81 & 12,52 \\
\hline Catalão - GO & 18925,0 & 3,92 & 99,42 & 1,71 & 14017,0 & 2,91 & 117,25 & 4,43 \\
\hline Goiás - GO & 31437,0 & 6,51 & 554,62 & 7,68 & 18517,0 & 3,85 & 338,43 & 10,72 \\
\hline Rio Verde - GO & 21292,0 & 4,41 & 227,74 & 3,75 & 15841,0 & 3,29 & 206,94 & 7,25 \\
\hline Paranaíba - MS & 24839,0 & 5,15 & 389,92 & 6,02 & 16615,0 & 3,44 & 245,64 & 8,36 \\
\hline Campo Grande - MS & 22044,0 & 4,57 & 302,67 & 4,91 & 16382,0 & 3,40 & 233,66 & 8,02 \\
\hline Sete Lagoas - MG & 14259,0 & 2,96 & $-139,22$ & $-2,63$ & 10813,0 & 2,25 & $-40,79$ & $-1,78$ \\
\hline Uberaba - MG & 18476,0 & 3,83 & 130,80 & 2,27 & 14964,0 & 3,11 & 163,87 & 5,95 \\
\hline Montes Claros - MG & 20882,0 & 4,33 & 51,71 & 0,86 & 11911,0 & 2,47 & 13,66 & 0,57 \\
\hline Linhares - ES & 25861,0 & 5,36 & 398,38 & 6,04 & 14631,0 & 3,04 & 147,19 & 5,41 \\
\hline Barreiras - BA & 29529,0 & 6,12 & 414,94 & 5,92 & 13479,0 & 2,80 & 90,62 & 3,50 \\
\hline Caetité - BA & 15521,0 & 3,21 & $-106,61$ & $-1,96$ & 10666,0 & 2,21 & $-47,65$ & $-2,10$ \\
\hline Boa Vista - RR & 41714,0 & 8,64 & 773,29 & 9,23 & 19293,0 & 3,98 & 378,59 & 11,72 \\
\hline Morada Nova - CE & 37018,0 & 7,68 & 449,47 & 5,72 & 10611,0 & 2,21 & $-51,01$ & $-2,25$ \\
\hline Picos - PI & 41771,0 & 8,64 & 439,03 & 5,24 & 8548,0 & 1,79 & $-152,76$ & $-7,49$ \\
\hline Imperatriz - MA & 38540,0 & 7,98 & 730,53 & 9,11 & 18426,0 & 3,83 & 333,61 & 10,59 \\
\hline Porto Nacional - TO & 37125,0 & 7,68 & 735,85 & 9,37 & 20022,0 & 4,16 & 412,49 & 12,40 \\
\hline Cuiabá - MT & 34811,0 & 7,20 & 602,65 & 7,93 & 14880,0 & 3,10 & 158,57 & 5,76 \\
\hline Cáceres - MT & 32921,0 & 6,82 & 594,08 & 8,04 & 16603,0 & 3,44 & 244,55 & 8,32 \\
\hline Brasília - DF & 15022,0 & 3,11 & $-71,61$ & $-1,33$ & 11642,0 & 2,41 & 0,67 & 0,03 \\
\hline Petrolina - PE & 37461,0 & 7,76 & 444,42 & 5,63 & 8404,0 & 1,76 & $-159,95$ & $-7,91$ \\
\hline
\end{tabular}


Conforme pode ser observado na Tabela 12, existe variação da produção de matéria seca em $\mathrm{kg} \mathrm{ha}{ }^{-1} \mathrm{ano}^{-1}$ de região para região; o que mais influencia essa diferenças são as condições climáticas: temperatura média anual e latitude do município estudado, este último fator influencia o fotoperíodo, provocando a estacionalidade de produção em certas localidades. Outro fator importante é o uso da irrigação para suprir as deficiências hídricas da região, bem como os possíveis veranicos que podem prejudicar em muito a produção média de matéria seca produzida no ano.

O município de Boa Vista - RR, onde a temperatura média anual é de $27,4{ }^{\circ} \mathrm{C}$, com ganho de peso diário dos animais $0,75 \mathrm{~kg}$ de $\mathrm{PV} \mathrm{dia}{ }^{-1}$, nível de adubação $600 \mathrm{~kg} \mathrm{~N}$ $\mathrm{ha}^{-1} \mathrm{ano}^{-1}$, preço de venda da arroba $\mathrm{R} \$ 40,00$, teve uma produção da pastagem irrigada de 41714,0 kg de MS ha ${ }^{-1}$ ano $^{-1}$, com uma lotação média anual de 8,64 UA ha ${ }^{-1}$, lucro de R\$ 773,29 $\mathrm{ha}^{-1} \mathrm{ano}^{-1}$, taxa interna de retorno (TIR) de 9,23\%, para recria, sendo um bom resultado para poder investir na região com bom lucro e alta produtividade.

O município mais crítico, Sete Lagoas - MG, com ganho de peso diário dos animais $0,75 \mathrm{~kg}$ de PV dia ${ }^{-1}$, nível de adubação $600 \mathrm{~kg} \mathrm{~N} \mathrm{ha}^{-1} \mathrm{ano}^{-1}$, preço de venda da arroba R\$ 40,00, teve uma produção da pastagem irrigada de 14259,0 kg de MS $\mathrm{ha}^{-1}$ ano $^{-1}$, com uma lotação média anual de 2,96 UA ha ${ }^{-1}$, prejuízo de R\$-139,22 $\mathrm{ha}^{-1} \mathrm{ano}^{-1}$, para recria, pois a temperatura média anual é de $20,9{ }^{\circ} \mathrm{C}$, um dos fatores limitantes para o crescimento das plantas forrageiras, provocando uma estacionalidade muito mais acentuada no capim tanzânia.

Outro fator que elevou o prejuízo foi o custo da adubação, que é distribuído ao longo do ano mês a mês: no período do inverno, os custos de produção tornam-se elevados, provocados pela estacionalidade de produção do capim tanzânia, inviabilizando o sistema de pastagem irrigada e adubada, o pecuarista pode optar em não adubar no inverno, dividindo a dose de nitrogênio em 8 ou 9 aplicações ao ano, otimizando a adubação nitrogenada.

O município de Aragarças - GO, onde a temperatura média anual é de $24,9{ }^{\circ} \mathrm{C}$, com ganho de peso diário $0,75 \mathrm{~kg}$ de $\mathrm{PV} \mathrm{dia}{ }^{-1}$, nível de adubação $600 \mathrm{~kg} \mathrm{~N}^{-1} \mathrm{ano}^{-1}$, preço de venda da arroba $\mathrm{R} \$ 40,00$, teve uma produção da pastagem sequeiro de 20157,0 $\mathrm{kg}$ de MS ha ${ }^{-1}$ ano $^{-1}$, com uma lotação média anual de 4,19 UA ha ${ }^{-1}$, lucro de R\$ 418,81 
$\mathrm{ha}^{-1}$ ano $^{-1}$, taxa interna de retorno (TIR) de $12,52 \%$ ao ano, para recria, com um bom lucro e alta produtividade, mesmo em se tratando de pastagem de sequeiro.

Temos, na simulação, o município de Petrolina - PE, que resultou no maior prejuízo contabilizado, com ganho de peso diário dos animais $0,75 \mathrm{~kg}_{\text {de }} \mathrm{PV} \mathrm{dia}{ }^{-1}$, nível de adubação $600 \mathrm{~kg} \mathrm{~N} \mathrm{ha}^{-1} \mathrm{ano}^{-1}$, preço de venda da arroba $\mathrm{R} \$ 40,00$, produção da pastagem sequeiro de $8404,0 \mathrm{~kg}$ de MS ha ${ }^{-1}$ ano $^{-1}$, com uma lotação média anual de 1,76 $\mathrm{UA} \mathrm{ha}^{-1}$, prejuízo de R\$ $-159,95 \mathrm{ha}^{-1} \mathrm{ano}^{-1}$, para recria, pois sem a irrigação para suprir a deficiência hídrica da cultura, a produção de sequeiro se limitou aos $608 \mathrm{~mm}$ de precipitação anual e à temperatura média anual de $26,7{ }^{\circ} \mathrm{C}, \mathrm{A}$ água, nesse caso, constitui um dos fatores limitantes para o desenvolvimento das plantas forrageiras do gênero Panicum com exigência, de acordo com McCosker \& Teitzel (1975), de média anual de $1300 \mathrm{~mm}$. Outros fatores que contribuíram para o prejuízo foram a adubação nitrogenada e o custo de implantação da infra-estrutura de pastejo rotacionado.

Em Petrolina - PE, com a mesma simulação, obteve-se uma produção da pastagem irrigada de $37461,0 \mathrm{~kg}$ de $\mathrm{MS} \mathrm{ha}^{-1}$ ano $^{-1}$, com uma lotação média anual de 7,76 $\mathrm{UA} \mathrm{ha}^{-1}$, e lucro de $\mathrm{R} \$ 444,42 \mathrm{ha}^{-1}$ ano $^{-1}$, para recria.

Realizou-se um estudo de rentabilidade do sistema de pastagem irrigada e de sequeiro, para 25 municípios do Brasil, onde foi avaliada a rentabilidade ( $\left.\mathrm{R} \$ \mathrm{ha}^{-1} \mathrm{ano}^{-1}\right)$, a lotação média (UA ha-1) e a taxa interna de retorno (\%), simulados os seguintes fatores: ganho de peso diário dos animais $0,75 \mathrm{~kg}$ de $\mathrm{PV} \mathrm{dia}{ }^{-1}$, o tipo de manejo recria, nível de adubação $600 \mathrm{~kg} \mathrm{~N} \mathrm{ha}^{-1} \mathrm{ano}^{-1}$, preço de venda da arroba $\mathrm{R} \$ 40,00$, como mostram as Figuras 23 e 24. 


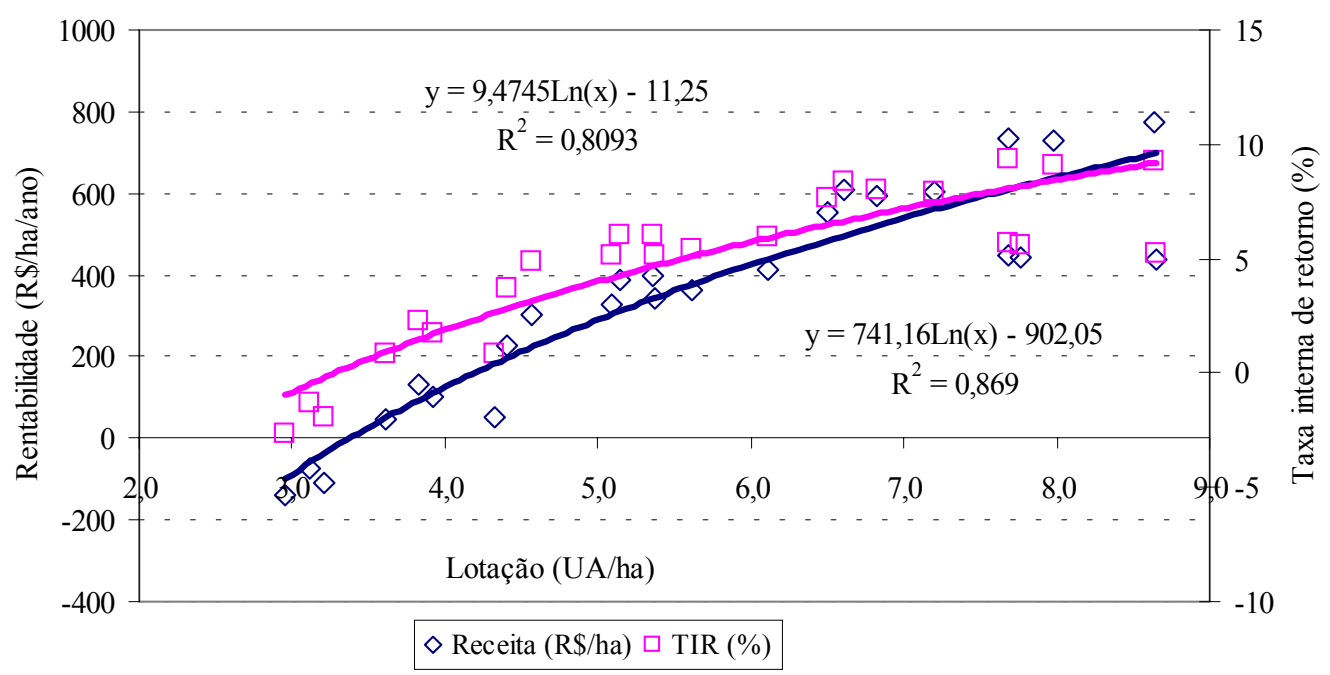

Figura 23 - Estudo da rentabilidade de pastagem irrigada para 25 municípios brasileiros, avaliando-se os seguintes fatores: receita líquida, lotação média anual e taxa interna de retorno.

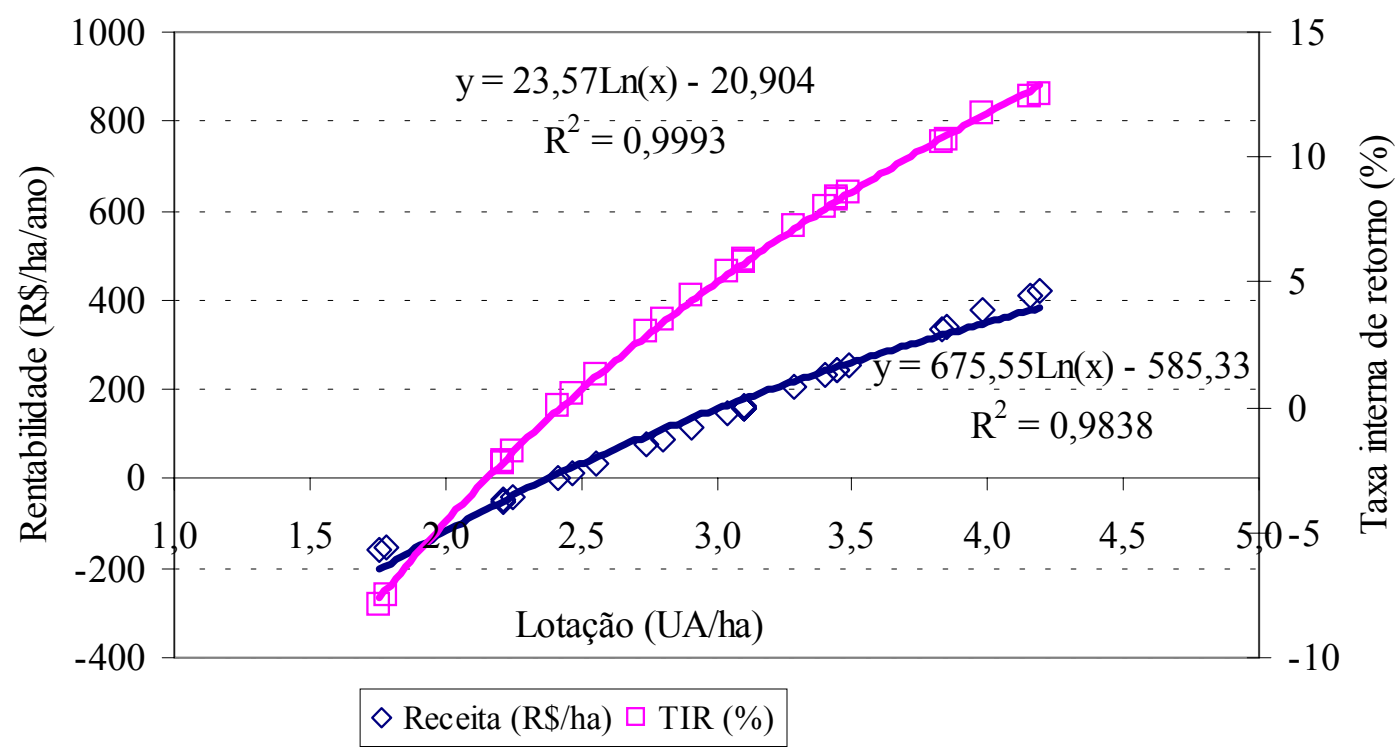

Figura 24 - Estudo da rentabilidade de pastagem sequeiro para 25 municípios brasileiros, avaliando-se os seguintes fatores: receita líquida, lotação média anual e taxa interna de retorno. 
Com base na análise de rentabilidade mostrada na Figura 23, pode-se dizer que existe relação direta entre lotação, receita e taxa interna de retorno, para a pastagem irrigada de capim tanzânia. Verificou-se que, quanto maior a lotação, mais alta é a receita e o seu retorno econômico ou a taxa interna de retorno para o produtor; verificouse também o ponto de inflexão da pastagem irrigada acima de 3,61 UA ha ${ }^{-1}$ ano $^{-1}$, com uma receita de $\mathrm{R} \$ 48,86 \mathrm{ha}^{-1} \mathrm{ano}^{-1}$ e a taxa interna de retorno de $0,87 \%$ ao ano.

O estudo para a pastagem de sequeiro também tem uma relação direta entre lotação, receita e taxa interna de retorno, observando-se que, quanto maior a lotação, mais alta é a receita e o seu retorno econômico ou a taxa interna de retorno, mas o ponto de inflexão se dá a uma menor lotação acima de $2,41 \mathrm{UA} \mathrm{ha}^{-1} \mathrm{ano}^{-1}$, com a receita de R\$ 0,67 $\mathrm{ha}^{-1} \mathrm{ano}^{-1}$ e a taxa interna de retorno de $0,03 \%$ ao ano, para os municípios analisados. 


\section{CONCLUSÕES}

- Em capim tanzânia, o fotoperíodo e a temperatura média diária, definem a produtividade ao longo do ano, mesmo com a eliminação do déficit hídrico no solo (irrigação). A estacionalidade da produção do capim tanzânia irrigado diminui, com a redução da latitude e da altitude local (maior temperatura média diária);

- A produtividade de matéria seca, para diferentes níveis de adubações nitrogenadas, apresentou boa correlação com a disponibilidade local de unidades fototérmicas (UF), o que permitiu estimar, com relativa precisão, a produção do capim tanzânia irrigado em diversas regiões brasileiras, com base no modelo calibrado em campo;

- A adubação nitrogenada apresentou resposta linear para a produção, através do incremento de área foliar do capim tanzânia, maximizando a produção em condições climáticas favoráveis de fotoperíodo e de temperatura;

- A irrigação de pastagens no Brasil apresenta rentabilidade variável entre $\mathrm{R} \$+770,00$ e R\$-140,00 ha ${ }^{-1}$ ano $^{-1}$, em função dos preços de venda da arroba de carne, das condições climáticas locais e do tipo de manejo empregado. Dessa forma, a tomada de decisão da irrigação de pastagens deve ser realizada caso a caso, evitando-se optar por esse empreendimento apenas por modismo. 
ANEXOS 
ANEXO A: Dados climáticos

Tabela 13. Temperatura máxima $\left(\mathrm{Tx},{ }^{\circ} \mathrm{C}\right)$, temperatura mínima $\left(\mathrm{Tm},{ }^{\circ} \mathrm{C}\right)$, temperatura média $\left(\mathrm{T},{ }^{\circ} \mathrm{C}\right)$ e chuva $(\mathrm{P}, \mathrm{mm})$ referentes ao $1^{\circ}$ corte, ano agrícola de 2001 . Fazenda Areão - ESALQ/USP, Piracicaba - SP.

\begin{tabular}{|c|c|c|c|c|}
\hline Dia/Mês & $\mathrm{Tx}$ & $\mathrm{Tm}$ & $\mathrm{T}$ & $\mathrm{P}$ \\
\hline 02/Jan & 35,8 & 17,9 & 26,9 & 0,0 \\
\hline 03/Jan & 38,4 & 17,9 & 28,2 & 0,0 \\
\hline $04 /$ Jan & 31,6 & 19,8 & 25,7 & 14,7 \\
\hline 05/Jan & 32,8 & 19,8 & 26,3 & 3,1 \\
\hline 06/Jan & 36,6 & 21,3 & 29,0 & 0,0 \\
\hline 07/Jan & 39,3 & 21,3 & 30,3 & 0,0 \\
\hline 08/Jan & 32,8 & 21,0 & 26,9 & 0,0 \\
\hline 09/Jan & 38,4 & 21,3 & 29,9 & 0,0 \\
\hline $10 /$ Jan & 35,3 & 20,2 & 27,8 & 0,8 \\
\hline $11 / \mathrm{Jan}$ & 38,8 & 20,2 & 29,5 & 0,0 \\
\hline $12 / \mathrm{Jan}$ & 41,4 & 17,9 & 29,7 & 33,7 \\
\hline 13/Jan & 36,6 & 17,5 & 27,1 & 5,6 \\
\hline $14 / \mathrm{Jan}$ & 39,7 & 17,9 & 28,8 & 0,0 \\
\hline $15 /$ Jan & 45,4 & 19,0 & 32,2 & 21,0 \\
\hline $16 /$ Jan & 40,6 & 18,7 & 29,7 & 0,3 \\
\hline 17/Jan & 25,2 & 21,3 & 23,3 & 0,0 \\
\hline 18/Jan & 26,0 & 19,8 & 22,9 & 61,0 \\
\hline $19 /$ Jan & 26,4 & 18,3 & 22,4 & 0,0 \\
\hline $20 / \mathrm{Jan}$ & 24,4 & 18,7 & 21,6 & 0,0 \\
\hline $21 /$ Jan & 23,7 & 19,8 & 21,8 & 0,0 \\
\hline 22/Jan & 24,4 & 19,0 & 21,7 & 0,0 \\
\hline $23 / \mathrm{Jan}$ & 24,8 & 20,6 & 22,7 & 0,0 \\
\hline $24 /$ Jan & 25,2 & 21,0 & 23,1 & 12,0 \\
\hline $25 / \mathrm{Jan}$ & 25,6 & 21,0 & 23,3 & 22,0 \\
\hline 26/Jan & 24,4 & 20,6 & 22,5 & 12,0 \\
\hline $27 /$ Jan & 26,4 & 20,2 & 23,3 & 27,9 \\
\hline $28 /$ Jan & 26,0 & 19,8 & 22,9 & 17,5 \\
\hline 29/Jan & 24,8 & 19,8 & 22,3 & 0,0 \\
\hline $30 / \mathrm{Jan}$ & 27,6 & 21,7 & 24,7 & 0,0 \\
\hline 31/Jan & 29,9 & 21,7 & 25,8 & 18,5 \\
\hline $01 / \mathrm{Fev}$ & 31,2 & 20,2 & 25,7 & 0,0 \\
\hline $02 / \mathrm{Fev}$ & 32,8 & 21,3 & 27,1 & 0,0 \\
\hline $03 / \mathrm{Fev}$ & 31,6 & 22,1 & 26,9 & 0,0 \\
\hline $04 / \mathrm{Fev}$ & 32,8 & 21,7 & 27,3 & 0,0 \\
\hline $05 / \mathrm{Fev}$ & 30,4 & 19,4 & 24,9 & 12,2 \\
\hline $06 / \mathrm{Fev}$ & 28,0 & 20,6 & 24,3 & 12,4 \\
\hline Média & 31,5 & 20,0 & 25,8 & 274,7 \\
\hline
\end{tabular}


Tabela 14. Temperatura máxima $\left(\mathrm{Tx},{ }^{\circ} \mathrm{C}\right)$, temperatura mínima $\left(\mathrm{Tm},{ }^{\circ} \mathrm{C}\right)$, temperatura média $\left(\mathrm{T},{ }^{\circ} \mathrm{C}\right)$ e chuva $(\mathrm{P}, \mathrm{mm})$ referentes ao $2^{\circ}$ corte, ano agrícola de 2001. Fazenda Areão - ESALQ/USP, Piracicaba - SP.

\begin{tabular}{|c|c|c|c|c|}
\hline Dia/Mês & $\mathrm{Tx}$ & $\mathrm{Tm}$ & $\mathrm{T}$ & $\mathrm{P}$ \\
\hline $14 / \mathrm{Fev}$ & 29,1 & 21,0 & 25,1 & 3,5 \\
\hline $15 / \mathrm{Fev}$ & 29,9 & 20,2 & 25,1 & 9,1 \\
\hline $16 / \mathrm{Fev}$ & 29,5 & 20,6 & 25,1 & 1,3 \\
\hline $17 / \mathrm{Fev}$ & 29,9 & 21,3 & 25,6 & 1,3 \\
\hline $18 / \mathrm{Fev}$ & 31,2 & 19,0 & 25,1 & 0,0 \\
\hline $19 / \mathrm{Fev}$ & 32,8 & 19,8 & 26,3 & 0,0 \\
\hline $20 / \mathrm{Fev}$ & 32,0 & 21,0 & 26,5 & 0,0 \\
\hline $21 / \mathrm{Fev}$ & 32,8 & 20,2 & 26,5 & 0,0 \\
\hline $22 / \mathrm{Fev}$ & 32,0 & 20,6 & 26,3 & 0,0 \\
\hline $23 / \mathrm{Fev}$ & 33,2 & 20,6 & 26,9 & 9,1 \\
\hline $24 / \mathrm{Fev}$ & 32,0 & 18,7 & 25,4 & 0,0 \\
\hline $25 / \mathrm{Fev}$ & 32,8 & 19,4 & 26,1 & 2,5 \\
\hline $26 / \mathrm{Fev}$ & 32,4 & 19,8 & 26,1 & 0,0 \\
\hline $27 / \mathrm{Fev}$ & 31,2 & 19,8 & 25,5 & 0,0 \\
\hline $28 / \mathrm{Fev}$ & 31,2 & 17,9 & 24,6 & 0,0 \\
\hline 01/Mar & 31,6 & 18,3 & 25,0 & 0,5 \\
\hline 02/Mar & 31,2 & 19,0 & 25,1 & 0,0 \\
\hline 03/Mar & 31,2 & 17,9 & 24,6 & 0,0 \\
\hline 04/Mar & 31,2 & 17,1 & 24,2 & 0,0 \\
\hline 05/Mar & 30,8 & 19,0 & 24,9 & 3,1 \\
\hline 06/Mar & 30,4 & 19,4 & 24,9 & 0,3 \\
\hline 07/Mar & 28,3 & 21,7 & 25,0 & 0,0 \\
\hline 08/Mar & 24,4 & 20,6 & 22,5 & 11,2 \\
\hline 09/Mar & 26,4 & 20,6 & 23,5 & 5,1 \\
\hline 10/Mar & 27,6 & 20,2 & 23,9 & 41,3 \\
\hline 11/Mar & 29,5 & 20,2 & 24,9 & 0,3 \\
\hline 12/Mar & 29,9 & 17,1 & 23,5 & 0,3 \\
\hline 13/Mar & 30,8 & 19,8 & 25,3 & 0,0 \\
\hline 14/Mar & 31,2 & 20,2 & 25,7 & 0,0 \\
\hline 15/Mar & 32,8 & 21,0 & 26,9 & 0,0 \\
\hline 16/Mar & 32,4 & 22,9 & 27,7 & 0,0 \\
\hline 17/Mar & 32,4 & 21,0 & 26,7 & 16,0 \\
\hline 18/Mar & 30,4 & 19,8 & 25,1 & 0,3 \\
\hline 19/Mar & 29,9 & 19,4 & 24,7 & 0,0 \\
\hline 20/Mar & 30,4 & 19,4 & 24,9 & 0,0 \\
\hline 21/Mar & 31,2 & 19,8 & 25,5 & 0,0 \\
\hline Média & 30,7 & 19,8 & 25,3 & 105,0 \\
\hline
\end{tabular}


Tabela 15. Temperatura máxima $\left(\mathrm{Tx},{ }^{\circ} \mathrm{C}\right)$, temperatura mínima $\left(\mathrm{Tm},{ }^{\circ} \mathrm{C}\right)$, temperatura média $\left(\mathrm{T},{ }^{\circ} \mathrm{C}\right)$ e chuva $(\mathrm{P}, \mathrm{mm})$ referentes ao $3^{\circ}$ corte, ano agrícola de 2001. Fazenda Areão - ESALQ/USP, Piracicaba - SP.

\begin{tabular}{|c|c|c|c|c|}
\hline Dia/Mês & $\mathrm{Tx}$ & $\mathrm{Tm}$ & $\mathrm{T}$ & $\mathrm{P}$ \\
\hline 30/Mar & 30,4 & 18,3 & 24,4 & 0,0 \\
\hline 31/Mar & 29,9 & 18,3 & 24,1 & 0,0 \\
\hline 01/Abr & 31,2 & 19,0 & 25,1 & 21,1 \\
\hline $02 / \mathrm{Abr}$ & 25,6 & 19,0 & 22,3 & 9,1 \\
\hline 03/Abr & 28,7 & 17,9 & 23,3 & 0,0 \\
\hline 04/Abr & 29,9 & 16,8 & 23,4 & 0,0 \\
\hline 05/Abr & 30,8 & 18,7 & 24,8 & 0,0 \\
\hline 06/Abr & 32,0 & 21,0 & 26,5 & 7,4 \\
\hline 07/Abr & 31,2 & 20,6 & 25,9 & 0,0 \\
\hline 08/Abr & 30,8 & 19,0 & 24,9 & 0,0 \\
\hline 09/Abr & 30,4 & 18,7 & 24,6 & 0,0 \\
\hline $10 / \mathrm{Abr}$ & 31,2 & 21,0 & 26,1 & 0,0 \\
\hline $11 / \mathrm{Abr}$ & 30,8 & 19,8 & 25,3 & 0,0 \\
\hline $12 / \mathrm{Abr}$ & 28,7 & 18,7 & 23,7 & 0,0 \\
\hline $13 / \mathrm{Abr}$ & 28,3 & 14,8 & 21,6 & 0,0 \\
\hline $14 / \mathrm{Abr}$ & 28,7 & 14,4 & 21,6 & 0,0 \\
\hline $15 / \mathrm{Abr}$ & 29,5 & 15,2 & 22,4 & 0,0 \\
\hline $16 / \mathrm{Abr}$ & 29,5 & 16,0 & 22,8 & 0,0 \\
\hline $17 / \mathrm{Abr}$ & 28,3 & 14,4 & 21,4 & 0,0 \\
\hline $18 / \mathrm{Abr}$ & 29,1 & 14,4 & 21,8 & 0,0 \\
\hline 19/Abr & 29,5 & 14,4 & 22,0 & 0,0 \\
\hline 20/Abr & 30,8 & 14,4 & 22,6 & 0,0 \\
\hline $21 / \mathrm{Abr}$ & 31,6 & 15,6 & 23,6 & 0,0 \\
\hline $22 / \mathrm{Abr}$ & 24,0 & 18,3 & 21,2 & 0,0 \\
\hline $23 / \mathrm{Abr}$ & 31,6 & 19,0 & 25,3 & 0,0 \\
\hline $24 / \mathrm{Abr}$ & 30,8 & 19,8 & 25,3 & 0,0 \\
\hline $25 / \mathrm{Abr}$ & 31,6 & 19,4 & 25,5 & 0,0 \\
\hline 26/Abr & 30,8 & 16,4 & 23,6 & 0,0 \\
\hline $27 / \mathrm{Abr}$ & 32,0 & 14,1 & 23,1 & 0,0 \\
\hline 28/Abr & 31,2 & 16,4 & 23,8 & 0,0 \\
\hline 29/Abr & 31,6 & 14,4 & 23,0 & 0,0 \\
\hline $30 / \mathrm{Abr}$ & 30,4 & 16,0 & 23,2 & 0,0 \\
\hline 01/Mai & 30,4 & 15,2 & 22,8 & 0,0 \\
\hline 02/Mai & 32,0 & 17,1 & 24,6 & 0,0 \\
\hline 03/Mai & 32,0 & 17,9 & 25,0 & 0,0 \\
\hline 04/Mai & 30,8 & 16,4 & 23,6 & 1,5 \\
\hline Média & 30,2 & 17,2 & 23,7 & 39,1 \\
\hline
\end{tabular}


Tabela 16. Temperatura máxima $\left(\mathrm{Tx},{ }^{\circ} \mathrm{C}\right)$, temperatura mínima $\left(\mathrm{Tm},{ }^{\circ} \mathrm{C}\right)$, temperatura média $\left(\mathrm{T},{ }^{\circ} \mathrm{C}\right)$ e chuva $(\mathrm{P}, \mathrm{mm})$ referentes ao $4^{\circ}$ corte, ano agrícola de 2001. Fazenda Areão - ESALQ/USP, Piracicaba - SP.

\begin{tabular}{|c|c|c|c|c|}
\hline Dia/Mês & $\mathrm{Tx}$ & $\mathrm{Tm}$ & $\mathrm{T}$ & $\mathrm{P}$ \\
\hline 11/Mai & 25,2 & 17,1 & 21,2 & 4,6 \\
\hline 12/Mai & 25,2 & 17,9 & 21,6 & 0,0 \\
\hline 13/Mai & 24,0 & 16,8 & 20,4 & 21,7 \\
\hline 14/Mai & 20,6 & 14,1 & 17,4 & 0,0 \\
\hline 15/Mai & 22,9 & 11,3 & 17,1 & 0,0 \\
\hline 16/Mai & 17,1 & 15,2 & 16,2 & 11,2 \\
\hline 17/Mai & 21,7 & 11,3 & 16,5 & 0,0 \\
\hline 18/Mai & 21,3 & 7,3 & 14,3 & 0,0 \\
\hline 19/Mai & 21,7 & 6,9 & 14,3 & 0,0 \\
\hline 20/Mai & 25,2 & 9,0 & 17,1 & 0,0 \\
\hline 21/Mai & 25,6 & 10,9 & 18,3 & 0,0 \\
\hline 22/Mai & 21,3 & 12,5 & 16,9 & 0,0 \\
\hline 23/Mai & 23,3 & 12,1 & 17,7 & 0,0 \\
\hline 24/Mai & 25,6 & 12,5 & 19,1 & 0,0 \\
\hline 25/Mai & 24,0 & 12,9 & 18,5 & 0,0 \\
\hline 26/Mai & 26,0 & 12,9 & 19,5 & 0,0 \\
\hline 27/Mai & 20,2 & 16,8 & 18,5 & 7,2 \\
\hline 28/Mai & 23,7 & 16,0 & 19,9 & 0,0 \\
\hline 29/Mai & 27,6 & 16,0 & 21,8 & 0,3 \\
\hline 30/Mai & 27,6 & 14,1 & 20,9 & 0,0 \\
\hline 31/Mai & 27,6 & 12,5 & 20,1 & 0,0 \\
\hline 01/Jun & 29,1 & 12,9 & 21,0 & 0,0 \\
\hline 02/Jun & 28,7 & 14,1 & 21,4 & 0,0 \\
\hline 03/Jun & 28,0 & 13,3 & 20,7 & 0,0 \\
\hline 04/Jun & 29,5 & 14,1 & 21,8 & 0,0 \\
\hline 05/Jun & 28,0 & 14,8 & 21,4 & 0,0 \\
\hline 06/Jun & 28,7 & 14,1 & 21,4 & 0,0 \\
\hline 07/Jun & 26,4 & 13,7 & 20,1 & 0,0 \\
\hline 08/Jun & 25,2 & 15,6 & 20,4 & 0,0 \\
\hline 09/Jun & 26,4 & 15,6 & 21,0 & 0,0 \\
\hline 10/Jun & 25,6 & 15,6 & 20,6 & 0,0 \\
\hline 11/Jun & 25,6 & 14,1 & 19,9 & 0,0 \\
\hline $12 /$ Jun & 25,2 & 12,1 & 18,7 & 0,0 \\
\hline 13/Jun & 26,8 & 10,5 & 18,7 & 0,0 \\
\hline $14 /$ Jun & 27,6 & 12,1 & 19,9 & 0,0 \\
\hline $15 /$ Jun & 28,7 & 12,1 & 20,4 & 0,0 \\
\hline Média & 25,3 & 13,4 & 19,3 & 44,9 \\
\hline
\end{tabular}


Tabela 17. Temperatura máxima $\left(\mathrm{Tx},{ }^{\circ} \mathrm{C}\right)$, temperatura mínima $\left(\mathrm{Tm},{ }^{\circ} \mathrm{C}\right)$, temperatura média $\left(\mathrm{T},{ }^{\circ} \mathrm{C}\right)$ e chuva $(\mathrm{P}, \mathrm{mm})$ referentes ao $5^{\circ}$ corte, ano agrícola de 2001. Fazenda Areão - ESALQ/USP, Piracicaba - SP.

\begin{tabular}{|c|c|c|c|c|}
\hline Dia/Mês & $\mathrm{Tx}$ & $\mathrm{Tm}$ & $\mathrm{T}$ & $\mathrm{P}$ \\
\hline 20/Jun & 20,2 & 11,3 & 15,8 & 0,0 \\
\hline 21/Jun & 16,8 & 6,5 & 11,7 & 0,0 \\
\hline 22/Jun & 19,4 & 3,6 & 11,5 & 0,0 \\
\hline 23/Jun & 25,6 & 9,8 & 17,7 & 0,0 \\
\hline 24/Jun & 26,6 & 11,3 & 19,0 & 0,0 \\
\hline 25/Jun & 28,7 & 12,5 & 20,6 & 0,0 \\
\hline 26/Jun & 20,6 & 10,5 & 15,6 & 16,5 \\
\hline 27/Jun & 17,1 & 4,9 & 11,0 & 0,8 \\
\hline 28/Jun & 19,4 & 8,2 & 13,8 & 0,0 \\
\hline 29/Jun & 21,3 & 7,3 & 14,3 & 0,0 \\
\hline 30/Jun & 25,2 & 8,6 & 16,9 & 0,0 \\
\hline 01/Jul & 26,4 & 8,6 & 17,5 & 0,0 \\
\hline $02 / \mathrm{Jul}$ & 28,7 & 9,0 & 18,9 & 0,0 \\
\hline 03/Jul & 28,0 & 11,3 & 19,7 & 0,0 \\
\hline 04/Jul & 29,1 & 10,5 & 19,8 & 0,0 \\
\hline 05/Jul & 28,7 & 9,0 & 18,9 & 0,0 \\
\hline 06/Jul & 26,4 & 11,5 & 19,0 & 0,0 \\
\hline 07/Jul & 26,4 & 10,5 & 18,5 & 0,0 \\
\hline 08/Jul & 27,2 & 12,5 & 19,9 & 0,0 \\
\hline 09/Jul & 27,2 & 12,5 & 19,9 & 0,0 \\
\hline $10 / \mathrm{Jul}$ & 27,2 & 12,1 & 19,7 & 0,0 \\
\hline 11/Jul & 27,6 & 10,5 & 19,1 & 0,0 \\
\hline $12 / \mathrm{Jul}$ & 29,1 & 10,5 & 19,8 & 2,8 \\
\hline $13 / \mathrm{Jul}$ & 18,7 & 11,7 & 15,2 & 0,0 \\
\hline $14 / \mathrm{Jul}$ & 21,7 & 9,4 & 15,6 & 0,0 \\
\hline $15 / \mathrm{Jul}$ & 25,2 & 6,9 & 16,1 & 0,0 \\
\hline $16 / \mathrm{Jul}$ & 26,8 & 10,9 & 18,9 & 0,0 \\
\hline $17 / \mathrm{Jul}$ & 28,7 & 12,5 & 20,6 & 0,0 \\
\hline $18 / \mathrm{Jul}$ & 27,6 & 11,7 & 19,7 & 0,0 \\
\hline $19 / \mathrm{Jul}$ & 31,2 & 11,7 & 21,5 & 0,0 \\
\hline $20 / \mathrm{Jul}$ & 26,0 & 15,2 & 20,6 & 0,0 \\
\hline $21 / \mathrm{Jul}$ & 31,2 & 12,9 & 22,1 & 0,0 \\
\hline $22 / \mathrm{Jul}$ & 30,4 & 14,8 & 22,6 & 12,4 \\
\hline $23 / \mathrm{Jul}$ & 21,3 & 14,4 & 17,9 & 0,3 \\
\hline 24/Jul & 20,6 & 13,7 & 17,2 & 0,0 \\
\hline $25 / \mathrm{Jul}$ & 24,8 & 10,5 & 17,7 & 0,0 \\
\hline Média & 25,2 & 10,5 & 17,9 & 32,8 \\
\hline
\end{tabular}


Tabela 18. Temperatura máxima $\left(\mathrm{Tx},{ }^{\circ} \mathrm{C}\right)$, temperatura mínima $\left(\mathrm{Tm},{ }^{\circ} \mathrm{C}\right)$, temperatura média $\left(\mathrm{T},{ }^{\circ} \mathrm{C}\right)$ e chuva $(\mathrm{P}, \mathrm{mm})$ referentes ao $6^{\circ}$ corte, ano agrícola de 2001. Fazenda Areão - ESALQ/USP, Piracicaba - SP.

\begin{tabular}{|c|c|c|c|c|}
\hline Dia/Mês & $\mathrm{Tx}$ & $\mathrm{Tm}$ & $\mathrm{T}$ & $\mathrm{P}$ \\
\hline $27 / \mathrm{Jul}$ & 24,4 & 12,8 & 18,6 & 0,0 \\
\hline 28/Jul & 13,4 & 7,9 & 10,7 & 4,8 \\
\hline 29/Jul & 21,9 & 4,3 & 13,1 & 0,0 \\
\hline 30/Jul & 28,2 & 9,1 & 18,7 & 0,0 \\
\hline $31 / \mathrm{Jul}$ & 28,1 & 11,2 & 19,7 & 0,1 \\
\hline 01/Ago & 28,1 & 11,8 & 20,0 & 0,0 \\
\hline 02/Ago & 27,9 & 10,6 & 19,3 & 0,0 \\
\hline 03/Ago & 28,3 & 17,5 & 22,9 & 0,0 \\
\hline 04/Ago & 29,1 & 11,7 & 20,4 & 0,0 \\
\hline 05/Ago & 28,3 & 9,8 & 19,1 & 0,0 \\
\hline 06/Ago & 28,7 & 9,0 & 18,9 & 0,0 \\
\hline 07/Ago & 28,7 & 10,5 & 19,6 & 0,0 \\
\hline 08/Ago & 26,8 & 10,5 & 18,7 & 0,0 \\
\hline 09/Ago & 26,4 & 9,4 & 17,9 & 0,0 \\
\hline 10/Ago & 26,0 & 10,5 & 18,3 & 0,0 \\
\hline 11/Ago & 26,4 & 10,5 & 18,5 & 0,0 \\
\hline 12/Ago & 26,4 & 12,5 & 19,5 & 0,0 \\
\hline 13/Ago & 27,2 & 10,5 & 18,9 & 0,0 \\
\hline 14/Ago & 26,4 & 9,8 & 18,1 & 0,0 \\
\hline 15/Ago & 26,9 & 10,9 & 18,9 & 0,0 \\
\hline 16/Ago & 27,2 & 9,8 & 18,5 & 0,0 \\
\hline 17/Ago & 26,4 & 11,3 & 18,9 & 0,0 \\
\hline 18/Ago & 28,0 & 11,3 & 19,7 & 0,0 \\
\hline 19/Ago & 29,5 & 12,5 & 21,0 & 0,0 \\
\hline 20/Ago & 29,1 & 14,4 & 21,8 & 0,0 \\
\hline 21/Ago & 27,6 & 13,7 & 20,7 & 0,0 \\
\hline 22/Ago & 23,7 & 15,2 & 19,5 & 1,0 \\
\hline 23/Ago & 17,9 & 13,7 & 15,8 & 15,0 \\
\hline 24/Ago & 23,7 & 15,6 & 19,7 & 3,8 \\
\hline 25/Ago & 28,3 & 14,4 & 21,4 & 0,0 \\
\hline 26/Ago & 26,0 & 16,4 & 21,2 & 0,0 \\
\hline 27/Ago & 27,2 & 17,5 & 22,4 & 0,0 \\
\hline 28/Ago & 28,0 & 17,1 & 22,6 & 0,3 \\
\hline 29/Ago & 24,4 & 17,4 & 20,9 & 0,0 \\
\hline 30/Ago & 30,2 & 15,8 & 23,0 & 0,1 \\
\hline 31/Ago & 30,1 & 16,3 & 23,2 & 0,0 \\
\hline Média & 26,5 & 12,3 & 19,4 & 25,0 \\
\hline
\end{tabular}


Tabela 19. Temperatura máxima $\left(\mathrm{Tx},{ }^{\circ} \mathrm{C}\right)$, temperatura mínima $\left(\mathrm{Tm},{ }^{\circ} \mathrm{C}\right)$, temperatura média $\left(\mathrm{T},{ }^{\circ} \mathrm{C}\right)$ e chuva $(\mathrm{P}, \mathrm{mm})$ referentes ao $7^{\circ}$ corte, ano agrícola de 2001 . Fazenda Areão - ESALQ/USP, Piracicaba - SP.

\begin{tabular}{|c|c|c|c|c|}
\hline Dia/Mês & $\mathrm{Tx}$ & $\mathrm{Tm}$ & $\mathrm{T}$ & $\mathrm{P}$ \\
\hline 03/Set & 31,10 & 15,60 & 23,4 & 0,0 \\
\hline $04 /$ Set & 31,60 & 15,90 & 23,8 & 0,0 \\
\hline $05 /$ Set & 28,50 & 16,40 & 22,5 & 0,0 \\
\hline 06/Set & 26,60 & 15,40 & 21,0 & 0,0 \\
\hline $07 /$ Set & 26,60 & 15,70 & 21,2 & 0,0 \\
\hline $08 /$ Set & 30,20 & 12,60 & 21,4 & 0,0 \\
\hline 09/Set & 31,50 & 16,60 & 24,1 & 0,0 \\
\hline $10 /$ Set & 33,40 & 15,80 & 24,6 & 0,0 \\
\hline $11 /$ Set & 24,40 & 14,80 & 19,6 & 0,0 \\
\hline $12 / \mathrm{Set}$ & 26,00 & 11,70 & 18,9 & 0,0 \\
\hline $13 /$ Set & 31,60 & 11,30 & 21,5 & 10,0 \\
\hline $14 /$ Set & 20,60 & 18,30 & 19,5 & 27,0 \\
\hline $15 /$ Set & 24,40 & 17,90 & 21,2 & 5,6 \\
\hline $16 /$ Set & 22,90 & 10,10 & 16,5 & 0,0 \\
\hline $17 /$ Set & 19,80 & 7,30 & 13,6 & 0,0 \\
\hline $18 /$ Set & 23,30 & 10,90 & 17,1 & 0,0 \\
\hline $19 /$ Set & 25,60 & 9,80 & 17,7 & 0,0 \\
\hline $20 /$ Set & 27,60 & 11,70 & 19,7 & 0,0 \\
\hline $21 /$ Set & 27,60 & 13,70 & 20,7 & 0,0 \\
\hline $22 / \mathrm{Set}$ & 22,10 & 16,80 & 19,5 & 2,2 \\
\hline $23 /$ Set & 28,00 & 15,20 & 21,6 & 0,0 \\
\hline $24 / \mathrm{Set}$ & 30,40 & 16,00 & 23,2 & 0,0 \\
\hline $25 /$ Set & 28,70 & 18,30 & 23,5 & 0,0 \\
\hline $26 /$ Set & 27,20 & 18,70 & 23,0 & 0,0 \\
\hline $27 /$ Set & 23,30 & 18,30 & 20,8 & 2,8 \\
\hline $28 /$ Set & 30,80 & 16,80 & 23,8 & 0,0 \\
\hline $29 /$ Set & 28,30 & 17,50 & 22,9 & 0,0 \\
\hline $30 /$ Set & 31,20 & 16,40 & 23,8 & 0,0 \\
\hline 01/Out & 28,00 & 21,00 & 24,5 & 56,3 \\
\hline $02 /$ Out & 25,60 & 14,80 & 20,2 & 1,6 \\
\hline 03/Out & 26,40 & 12,90 & 19,7 & 0,0 \\
\hline 04/Out & 29,10 & 12,50 & 20,8 & 0,0 \\
\hline 05/Out & 30,80 & 15,60 & 23,2 & 0,0 \\
\hline 06/Out & 29,10 & 14,80 & 22,0 & 0,0 \\
\hline 07/Out & 29,50 & 16,00 & 22,8 & 9,7 \\
\hline 08/Out & 21,00 & 16,80 & 18,9 & 0,0 \\
\hline Média & 27,3 & 15,0 & 21,1 & 115,2 \\
\hline
\end{tabular}


Tabela 20. Temperatura máxima $\left(\mathrm{Tx},{ }^{\circ} \mathrm{C}\right)$, temperatura mínima $\left(\mathrm{Tm},{ }^{\circ} \mathrm{C}\right)$, temperatura média $\left(\mathrm{T},{ }^{\circ} \mathrm{C}\right)$ e chuva $(\mathrm{P}, \mathrm{mm})$ referentes ao $8^{\circ}$ corte, ano agrícola de 2001. Fazenda Areão - ESALQ/USP, Piracicaba - SP.

\begin{tabular}{|c|c|c|c|c|}
\hline Dia/Mês & $\mathrm{Tx}$ & $\mathrm{Tm}$ & $\mathrm{T}$ & $\mathrm{P}$ \\
\hline 10/Out & 27,1 & 18,9 & 23,0 & 22,0 \\
\hline 11/Out & 30,8 & 18,7 & 24,8 & 0,0 \\
\hline $12 /$ Out & 29,2 & 16,8 & 23,0 & 0,0 \\
\hline 13/Out & 29,2 & 16,8 & 23,0 & 0,0 \\
\hline 14/Out & 27,6 & 15,3 & 21,5 & 0,0 \\
\hline 15/Out & 29,4 & 15,8 & 22,6 & 0,0 \\
\hline 16/Out & 28,9 & 15,5 & 22,2 & 0,0 \\
\hline 17/Out & 27,9 & 16,1 & 22,0 & 18,8 \\
\hline 18/Out & 28,1 & 17,2 & 22,7 & 1,8 \\
\hline 19/Out & 28,7 & 17,5 & 23,1 & 10,2 \\
\hline 20/Out & 27,6 & 17,1 & 22,4 & 1,5 \\
\hline 21/Out & 29,5 & 16,0 & 22,8 & 3,8 \\
\hline $22 /$ Out & 27,6 & 17,5 & 22,6 & 10,4 \\
\hline 23/Out & 28,0 & 16,4 & 22,2 & 0,0 \\
\hline 24/Out & 28,7 & 13,3 & 21,0 & 0,0 \\
\hline 25/Out & 29,9 & 12,9 & 21,4 & 0,0 \\
\hline 26/Out & 29,9 & 13,3 & 21,6 & 0,0 \\
\hline 27/Out & 29,9 & 13,3 & 21,6 & 0,0 \\
\hline 28/Out & 31,8 & 14,1 & 23,0 & 0,0 \\
\hline 29/Out & 32,2 & 15,2 & 23,7 & 0,0 \\
\hline 30/Out & 34,1 & 16,8 & 25,5 & 0,0 \\
\hline 31/Out & 32,4 & 20,6 & 26,5 & 0,0 \\
\hline $01 / \mathrm{Nov}$ & 31,2 & 17,9 & 24,6 & 0,0 \\
\hline $02 / \mathrm{Nov}$ & 29,9 & 17,5 & 23,7 & 0,0 \\
\hline $03 /$ Nov & 24,0 & 16,4 & 20,2 & 0,0 \\
\hline $04 /$ Nov & 20,6 & 16,4 & 18,5 & 5,6 \\
\hline $05 / \mathrm{Nov}$ & 28,1 & 14,4 & 21,3 & 0,0 \\
\hline $06 / \mathrm{Nov}$ & 32,4 & 16,0 & 24,2 & 0,0 \\
\hline $07 / \mathrm{Nov}$ & 34,1 & 16,4 & 25,3 & 0,0 \\
\hline $08 /$ Nov & 32,2 & 20,2 & 26,2 & 0,0 \\
\hline 09/Nov & 33,2 & 19,4 & 26,3 & 0,0 \\
\hline $10 / \mathrm{Nov}$ & 33,2 & 20,2 & 26,7 & 0,0 \\
\hline $11 / \mathrm{Nov}$ & 29,9 & 19,8 & 24,9 & 27,9 \\
\hline $12 / \mathrm{Nov}$ & 24,4 & 20,2 & 22,3 & 0,0 \\
\hline $13 / \mathrm{Nov}$ & 27,2 & 19,4 & 23,3 & 16,3 \\
\hline $14 / \mathrm{Nov}$ & 28,7 & 19,4 & 24,1 & 10,2 \\
\hline Média & 29,4 & 16,9 & 23,1 & 128,4 \\
\hline
\end{tabular}


Tabela 21. Temperatura máxima $\left(\mathrm{Tx},{ }^{\circ} \mathrm{C}\right)$, temperatura mínima $\left(\mathrm{Tm},{ }^{\circ} \mathrm{C}\right)$, temperatura média $\left(\mathrm{T},{ }^{\circ} \mathrm{C}\right)$ e chuva $(\mathrm{P}, \mathrm{mm})$ referentes ao $9^{\circ}$ corte, ano agrícola de 2001. Fazenda Areão - ESALQ/USP, Piracicaba - SP.

\begin{tabular}{ccccc}
\hline Dia/Mês & Tx & Tm & $\mathrm{T}$ & $\mathrm{P}$ \\
\hline 16/Nov & 27,8 & 20,3 & 24,1 & 0,1 \\
17/Nov & 28,6 & 18,4 & 23,5 & 2,0 \\
18/Nov & 29,7 & 18,9 & 24,3 & 0,0 \\
19/Nov & 30,8 & 17,6 & 24,2 & 2,9 \\
20/Nov & 30,3 & 19,0 & 24,7 & 0,0 \\
21/Nov & 31,7 & 18,7 & 25,2 & 0,0 \\
22/Nov & 31,4 & 19,6 & 25,5 & 2,1 \\
23/Nov & 31,3 & 19,6 & 25,4 & 12,9 \\
24/Nov & 31,8 & 20,2 & 26,0 & 0,0 \\
25/Nov & 33,0 & 20,7 & 26,9 & 0,0 \\
26/Nov & 32,7 & 19,9 & 26,3 & 0,0 \\
27/Nov & 32,5 & 19,0 & 25,8 & 0,0 \\
28/Nov & 31,0 & 20,5 & 25,8 & 6,8 \\
29/Nov & 28,5 & 18,2 & 23,4 & 18,7 \\
30/Nov & 26,1 & 19,2 & 22,7 & 2,7 \\
01/Dez & 25,4 & 17,1 & 21,3 & 1,7 \\
02/Dez & 27,8 & 13,5 & 20,7 & 0,0 \\
03/Dez & 30,2 & 14,9 & 22,6 & 0,0 \\
04/Dez & 30,7 & 15,6 & 23,2 & 0 \\
05/Dez & 30,5 & 18,1 & 24,3 & 0,7 \\
06/Dez & 24,5 & 20,8 & 22,7 & 5,2 \\
07/Dez & 30,3 & 20,7 & 25,5 & 8,5 \\
08/Dez & 30,7 & 19,8 & 25,3 & 0,1 \\
09/Dez & 29,9 & 18,9 & 24,4 & 10,9 \\
10/Dez & 29,7 & 18,9 & 24,3 & 3,9 \\
11/Dez & 28,4 & 19,8 & 24,1 & 0,0 \\
12/Dez & 28,4 & 19,7 & 24,1 & 0,9 \\
13/Dez & 26,1 & 20,2 & 23,2 & 8,3 \\
14/Dez & 23,9 & 19,9 & 21,9 & 11,0 \\
15/Dez & 27,1 & 19,3 & 23,2 & 17,4 \\
16/Dez & 29,1 & 19,5 & 24,3 & 23,3 \\
17/Dez & 31,1 & 19,0 & 25,1 & 0,2 \\
18/Dez & 31,5 & 20,8 & 26,2 & 0,0 \\
19/Dez & 32,8 & 20,8 & 26,8 & 0,0 \\
20/Dez & 30,3 & 21,5 & 25,9 & 0,0 \\
21/Dez & 28,8 & 20,7 & 24,8 & 24,4 \\
Média & 29,6 & 19,1 & & \\
\hline & & & & 0,6 \\
\hline
\end{tabular}


ANEXO B: Tarifas Horo-sazonais Verde

Tabela 22. Preço das Tarifas Horo-sazonais Verde de Consumo e Demanda para três regiões brasileiras: Sudeste - Companhia Paulista de Força e Luz, 19/10/2001 (CPFL); Nordeste - Companhia Energética de Pernambuco, 19/10/2001 (CELPE) e Centro Oeste - Companhia Energética de Goiás S/A, 30/10/2001 (CELG).

\begin{tabular}{|c|c|c|c|}
\hline Segmento A4 (Verde) & Sudeste & Centro Oeste & Nordeste \\
\hline Demanda $\left(\mathrm{R} \$ \mathrm{~kW}^{-1}\right)$ & 6,37 & 6,52 & 4,66 \\
\hline $\begin{array}{l}\text { Demanda Ultrapassada } \\
\qquad\left(\mathrm{R} \$ \mathrm{~kW}^{-1}\right)\end{array}$ & 19,12 & 19,62 & 15,33 \\
\hline $\begin{array}{l}\text { Consumo Ponta Seca } \\
\qquad\left(\mathrm{R} \$ \mathrm{kWh}^{-1}\right)\end{array}$ & 0,56782 & 0,58230 & 0,46104 \\
\hline $\begin{array}{l}\text { Consumo Ponta Úmida } \\
\qquad\left(\mathrm{R} \$ \mathrm{kWh}^{-1}\right)\end{array}$ & 0,55850 & 0,57272 & 0,45347 \\
\hline $\begin{array}{l}\text { Consumo Fora Ponta Seca } \\
\qquad\left(\mathrm{R} \$ \mathrm{kWh}^{-1}\right)\end{array}$ & 0,05968 & 0,06118 & 0,04843 \\
\hline $\begin{array}{l}\text { Consumo Fora Ponta Úmida } \\
\qquad\left(\mathrm{R} \$ \mathrm{kWh}^{-1}\right)\end{array}$ & 0,05273 & 0,05407 & 0,05407 \\
\hline
\end{tabular}




\section{REFERÊNCIAS BIBLIOGRÁFICAS}

AGUIAR, A.P.; AMARAL, G.C.; DATENA, J.L. Possibilidade de produção de carne em sistemas intensivos de pastagens tropicais com animais de raças zebuínas. In: CONGRESSO BRASILEIRO DAS RAÇAS ZEBUINAS, 4., Uberaba, 2000. Anais. Uberaba: ABCZ, 2000, p.350-352.

ANDRADE, P. Acabamento de bovinos. In: SIMPÓSIO SOBRE PECUÁRIA DE CORTE, 3, Piracicaba, 1983. Anais. Piracicaba: FEALQ, 1983. p.127-141.

ARRUDA, Z.J. Eficiência econômica na alocação de recursos na agricultura. Campo Grande: EMBRAPA, CNPGC, 1982. 24p.

AZEVEDO FILHO, A.J.B.V. de. Análise econômica de projetos "software' para situações determinadas e risco envolvendo simulação. Piracicaba, 1988. 127p. Dissertação (Mestrado) - Escola Superior de Agricultura "Luiz de Queiroz", Universidade de São Paulo.

BATTY, J.C.; KELLER, J. Energy requeriments for irrigation. In: PIMENTEL, D. (Ed.). Handbook of energy utilization in agriculture. Boca Raton: CRC Press, 1980. p.35-44.

BERNUTH, R.D. Uniformity design criteria under limited water. Transactions of the ASAE, v.26, n.5, p.1418-1421, 1983. 
BONOMO, R.; MANTOVANI, E.C.; CAIXETA, G.Z.T. Comparação de custos para diferentes sistemas de irrigação empregados na cafeicultura em áreas cerrado de Minas Gerais (compact disc). In: CONGRESSO BRASILEIRO DE ENGENHARIA AGRÍCOLA, 28., Pelotas, 1999. Anais. Pelotas: UFPel, 1999.

BRASIL. Ministério da Agricultura e do Abastecimento. Custo de produção agrícola CONAB. Brasília: CONAB, 1996. 67p. (Coleção de Política Agrícola).

BURKART, A. Evolution of grasses and grasslands in South America. Taxon., v.24, n.1, p.53-66, Feb. 1975.

COOPER, J.P.; TAINTON, N.M. Light and temperature requirements for the growth of tropical and temperate grasses. Herbage Abstracts, v.38, n.3, p.167-176, 1968.

CARRIEL, J.M; PEDREIRA, J.V.S; MATTOS, H.B. Estimativa da ocorrência dos principais capins no Estado de São Paulo. Zootecnia, v.17, n.1, p.5-25, 1979.

CORSI, M. Adubação nitrogenada das pastagens. In: PEIXOTO, A.M. (Ed.) Pastagens: fundamentos da exploração racional. Piracicaba: FEALQ, 1986. p.109-132.

CORSI, M.; NUSSIO, L.G. Manejo do capim elefante: correção e adubação do solo. In: SIMPÓSIO SOBRE MANEJO DA PASTAGEM, 10., Piracicaba, 1993. Anais. Piracicaba: FEALQ, 1993. p.87-116.

CHANDLER, J. Intensive grassland management in Puerto Rico. Revista da Sociedade Brasileira de Zootecnia, v.2, n.2, p.173-215, 1973.

DENT, J.B.; ANDERSON, J.R. Systems analysis in agricultural management. Sidney: John Wiley, 1971. 394p. 
DOORENBOS, J.; KASSAM, A.H. Efeito da água no rendimento das culturas. Campina Grande: UFPb, 1994. 306p. ( Estudos FAO. Irrigação e Drenagem, 33).

ELLIS, T.O. A preliminary surver of the yields, composition and fertilizer responses of fodder grasses. Jamaica Depto. Agric., 1950. 31p. (Bulletin, 41).

FRANKE, A.E.; DORFMAN, R. Viabilidade econômica da irrigação, sob condições de risco, em regiões de clima subtropical. Pesquisa Agropecuária Brasileira, v.33, n.12, p.2003-2013, dez. 1998.

FRIZZONE, J.A. Planejamento da irrigação: uma abordagem às decisões de investimento. Piracicaba: ESALQ, Depto. Engenharia Rural, 1999. 110p.

FRIZZONE, J.A.; SILVEIRA, S.F.S. Análise econômica de projetos hidroagrícolas. In: SILVA, D.D.; PRUSKI, F.F. (Ed.) Gestão de recursos hídricos: Folha de Viçosa, 2000. cap.5, p.449-617.

FRIZZONE, J.A.; BOTREL, T.A.; FREITAS, H.A.C. Análise comparativa dos custos de irrigação por pivô central, em cultura de feijão utilizando energia elétrica e óleo diesel. Engenharia Rural, v.5, n.1, p. 35-53, jul. 1994.

GARCIA, J.A.R. Efeito de diferentes lâminas d'água sobre a cultura da aveia irrigada por inundação temporária. Lavras. 1993. 71p. Dissertação (Mestrado) - Escola Superior de Agricultura de Lavras.

GENEVILLE, M.S. Modelo de simulação do balanço hídrico e do crescimento de uma pastagem de gramínea para a região de Mato Grosso do Sul. In: SEMINÁRIO SOBRE A APLICAÇÃO DE UM ENFOQUE DE SISTEMAS NA PESQUISA DE PRODUÇÃO ANIMAL, 2., Campo Grande, 1978. Pesquisa biológica em sistemas. Campo Grande: EMBRAPA, CNPG, 1984. p.63-71. 
GHELFI FILHO, H. Efeito da irrigação sobre o capim colonião (Pennisetum purpureum Schum.) variedade Napier. Piracicaba, 1972. 101p. Dissertação (Mestrado) - Escola Superior de Agricultura "Luiz de Queiroz", Universidade de São Paulo.

GOMIDE, J.A. Adubação de pastagens estabelecidas. In: SIMPÓSIO SOBRE MANEJO DA PASTAGEM, 7., Piracicaba, 1984. Anais. Piracicaba: FEALQ, 1986. p.33-60.

GOMIDE, J.A. Fisiologia do crescimento livre de plantas forrageiras. In: PEIXOTO, A.M. (Ed.) Pastagens: fundamentos de exploração racional. Piracicaba: FEALQ, 1994. p.1-14.

HOFFMANN, R.; ENGLER, J.J.C.; SERRANO, O. Administração da empresa agrícola. 5. ed. São Paulo: Pioneira, 1987. 325p.

JANK, L.; BATISTONI, C.; FERREIRA, G. de F.C.R. Herança da característica estolonífera em Panicum maximum. In: REUNIÃO DA SOCIEDADE BRASILEIRA DE ZOOTECNIA, 31., Maringá, 1994. Anais. Maringá: SBZ, 1994. p.304-307.

KLINDER, J. Modeling derived demand for irritagation water. Agricultura Water Management, v.13, p. 403-410, 1988.

LANNA, D.P.D.; BARIONI, L.G.; MEDEIROS, S.R. Curso de formulação de ração para bovinos de corte com RLM 2.0 (Apostila). Piracicaba: ESALQ, 2001. 151p.

LEDGER, H.P.; ROGERSON, A.; FREEMAN, G.H. Further studies on the voluntary food intake of Bos indicus, Bos taurus and crossbreed catle. Animal Production, v.12, n.3, p.425-431, 1970. 
LI-COR. LAI-2000 plant canopy analyser: instruction manual. Lincoln, 1992. 182p.

MARCELINO, K.R.A.; LEITE, G.G.;VILELA, L. Efeito da adubação nitrogenada e da irrigação sobre a produtividade e índice de área foliar de duas gramíneas cultivadas no cerrado. In: REUNIÃO ANUAL DA SOCIEDADE BRASILEIRA DE ZOOTECNIA, 38., Piracicaba, 2001. Anais. Piracicaba: SBZ, 2001. p.230-231.

McCOSKER, T.H.; TEITZEL, J.D. A review of guinea grass (Panicum maximum) for the wet tropics of Australia. Tropical Grasslands, v.9, n.3, p.177-190, Nov. 1975.

McWILLIAM, J.R. Response of pasture plants to temperature. In: WILSON, J.R. Plant relations in temperature. Melbourne: Commonwealth Scientific Industrial Research Organization, 1978. p.17-34.

MELO, J.F. Custos da irrigação por aspersão em Minas Gerais. Viçosa, 1993. 147p. Dissertação (M.S) - Universidade Federal de Viçosa.

MOLINARI, O.G. Grasslands and grasses of Puerto Rico. Rio Piedras: University of Puerto Rico, 1952. 167p. (Bulletin, 102).

NABINGER, C. Princípios da exploração intensiva de pastagens. In: SIMPÓSIO SOBRE MANEJO DE PASTAGEM, 13., Piracicaba, 1997. Anais. Piracicaba: FEALQ, 1997. p.15-95.

NEUMANN, M.; RESTLE, J.; ALVES FILHO, D.C. Avaliação de diferentes híbridos de sorgo (Sorghum bicolor L. MOENCH) para produção de silagem. IV Desempenho de novilhos confinados. NUT: 0523. In: REUNIÃO ANUAL DA SOCIEDADE BRASILEIRA DE ZOOTECNIA, 37., Viçosa, 1999. Anais. Viçosa: SBZ., 1999. p.350-54. 
OVERMAN, A.R.; NEFF, C.R.; WILKINSON, S.R.; MARTIN, F.G. Water, harvest interval, and applied nitrogen effects on forage yield of Bermudagrass and Bahiagrass. Agronomy Journal, v.82, p.1011-1016, Sept./Oct. 1990.

PEDREIRA, J.V.S.; MATTOS, H.B. Crescimento estacional de vinte e cinco espécies ou variedades de capins. Boletim de Indústria Animal, v.38, n. 2, p.117-143, 1981.

PEIXOTO, A.M. Fatores que interferem no crescimento do gado de corte até a desmama. In: PEIXOTO, A.M.; MOURA, J.C.; FARIA, V.P. (Ed.) Bovinocultura de corte: fundamentos da exploração racional. 2. ed. Piracicaba: FEALQ, 1993. p.73-108.

PEREIRA, R.M.A.; SYKES, D.S.; GOMIDE, J.A.; VIDIGAL, G.T. Comparison of 10 grasses for cut green fodder in the cerrado in 1965. Ceres, v.13, n.74, p.141-153, 1966.

PEREIRA, W.M.; MATTOS, J.C.A.; BARBOSA, C.; SIQUEIRA, A.C.F. Ganho de peso de garrotes pertencentes à raça Nelore (Tipo comercial) e ao cruzamento Suíço x Guzerá (1/2 sangue), em confinamento. Boletin da Indústria Animal. v.31, n.1, p.67-73, 1974.

PERES, F.C. Confinamento de gado de corte: um modelo de análise de decisão. Piracicaba, 1990, 73p., Tese de (Livre docência) - Escola Superior de Agricultura “Luiz de Queiroz”, Universidade de São Paulo.

PORTUGAL, A.D. A relação entre o consumo de energia e a prática da agricultura irrigada. ITEM: Irrigação \& Tecnologia Moderna, n.50, p.10-11, 2001.

RAZOOK, A.G. Seleção em bovinos de corte. II. Resultados experimentais. Zootecnia, v.1, n.26, p.27-50, jan./mar. 1988. 
ROLIM, F.A. Estacionalidade de produção de forrageiras. In: SIMPÓSIO SOBRE MANEJO DE PASTAGENS, 6., Piracicaba, 1980. Anais. Piracicaba: ESALQ, 1980. p.39-81.

ROCHA, G.L. Ecossistema de pastagens: aspectos dinâmicos. Piracicaba: Sociedade Brasileira de Zootecnia; FEALQ, 1991. 391p.

SANTANA, O.P.; CALDAS, G.C. Níveis de uréia em capim colonião, no arroçoamento de novilhos mestiços confinados. Revista da Sociedade Brasileira de Zootecnia, v.2, n.1, p.66-81, 1973.

SCALOPPI, E.J. Exigências de energia para irrigação. ITEM: Irrigação \& Tecnologia Moderna, n.21, p.13-17, 1985.

SENTElHAS, P.C.; ROLIM, G.S. Software Balanço Hídrico Normal v5.0 BRASIL. Piracicaba: ESALQ, Depto. Física e Meteorologia, 1999.

SENTELHAS, P.C.; PEREIRA, A.R.; ANGELOCCI, L.R. Meteorologia agrícola. Piracicaba: ESALQ, 1999. 125p.

SKERMAN, P.J.; RIVEROS, F. Gramíneas tropicales. Rome: FAO, 1992. 849p. (FAO. Producción y Protección Vegetal, 23).

SOTO, H.A.H. Um modelo simples de estimativa de produção de forragem para colonião (Panicum maximum Jacq.) e pangola (A-24 Digitaria pentzii Stent) usando parâmetros climáticos. Piracicaba, 1981. 101p. Dissertação (Mestrado) - Escola Superior de Agricultura “Luiz de Queiroz”, Universidade de São Paulo. 
SOUZA, V.G.; PEREIRA, O.G.; RIBEIRO, K.G. Consumo, ganho de peso e conversão alimentar de bovinos de corte recebendo rações à base de silagem de sorgo e présecado de capim Tifton 85. In: REUNIÃO ANUAL DA SOCIEDADE BRASILEIRA DE ZOOTECNIA, 38., Piracicaba, 2001. Anais. Piracicaba: SBZ, 2001. p.1237-1238.

TATIZANA, S.A. Um modelo conceitual de simulação da produção de gado de corte. Piracicaba, 1995. 95p. Dissertação (Mestrado) - Escola Superior de Agricultura “Luiz de Queiroz”, Universidade de São Paulo.

THORNTHWAITE, C.W.; MATHER, J.R. The water balance. New Jersey: Drexel Inst. of Technology, 1995. 104p. (Publications in Climatology).

TURRA, F.E. Análise de diferentes métodos de cálculo de custos de produção na agricultura brasileira. Piracicaba, 1990. 134p. Dissertação (Mestrado) - Escola Superior de Agricultura "Luiz de Queiroz”, Universidade de São Paulo.

TURCK, G.; WHITE, J.E.. Sinall scale irrigation in southern. Rhodesia Agriculture, v.54, n.5, p.45-48, 1954.

VELLOSO, L.; FIGUEIREDO, B.M. Estudo sobre o consumo de matéria seca de bovinos Nelore mantidos em regime de confinamento. Boletim da Indústria Animal, n. 27/28, p.305-312, 1970/71.

VELloSO, L.; BOIN, C.; ROCHA, G.L. Novilhos Pintangueiras comparados a novilhos Nelore em confinamento. Boletim da Indústria Animal. v.32, n.1, p.1521, 1975. 
VILELA, H.; SILVESTRE, J.R.A.; VILELA. D. Silagem de sorgo e pé de sorgo seco desintegrado como fonte de volumoso para novilhos em confinamento. Revista da Sociedade Brasileira de Zootecnia. v.2, n.1, p.82-92, 1973.

VILLA NOVA, N.A.; CARRETEIRO, M.V.; SCARDUA, R. Um modelo de avaliação do crescimento de cana-de-açúcar (Saccharum spp.) em termos da ação combinada do fotoperíodo e da temperatura média do ar. In: CONGRESSO BRASILEIRO DE AgrometeorologiA, 2., Campinas, 1983. Anais. Campinas: Sociedade Brasileira de Agrometeorologia; Instituto Agronômico de Campinas, 1983. p.31-48.

VILLA NOVA, N.A.; BARIONI, L.G.; PEDREIRA, C.G.S.; PEREIRA, A.R. Modelo para previsão da produtividade do capim elefante em função de temperatura do ar, fotoperíodo e freqüência de desfolha. Revista Brasileira de Agrometeorologia, v.7, n.1, p.75-79, 1999.

VILLA NOVA, N.A.; PEDRO Jr., M.J.; PEREIRA, A.R.; OMETTO, J.C. Estimativa de graus dia acumulados acima de qualquer temperatura base, em função de temperaturas máxima e mínima. Cadernos de Ciências da Terra, n.30, p.1-7, 1972.

WELLES, J.M. Some indirect methods of estimating canopy structure. In: GOEL, N.S.; NORMAN, J.M. (Ed). Instrumentation for studying vegetation canopies for remote sensing in optical and thermal infrared regions. London: Harwood Academy, 1990. cap. 5, p.31-43.

XAVIER, A.C.; LOURENÇO, L.F.; COELHO, R.D. Modelo matemático para manejo da irrigação por tensiômetria em pastagem (Panicum maximum jacq.) rotacionada sob pivô central. In: REUNIÃO ANUAL DA SOCIEDADE BRASILEIRA DE ZOOTECNIA, 38., Piracicaba, 2001. Anais. Piracicaba: SBZ, 2001. p.249-250. 